ANGELA O'MEARA

\title{
MĀORI PURPOSES ACTS: JUST "WASHING-UP" OR MORE THAN MEETS THE EYE?
}

\section{LAWS 591: LLM THESIS}

\section{FACULTY OF LAW}

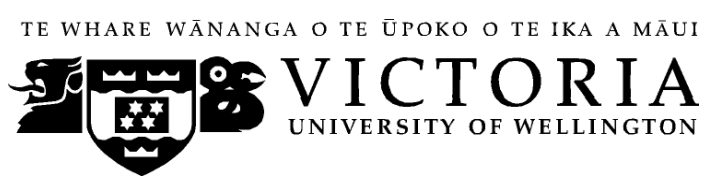

2019 


\section{Contents}

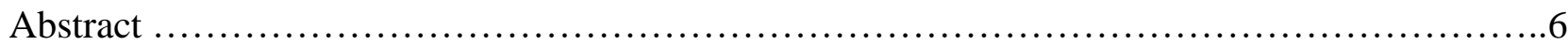

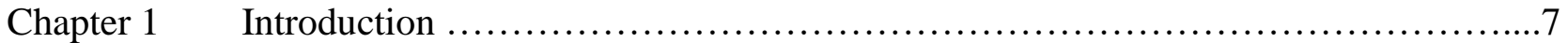

I Origins of the Legislation

II Content and Trends

III What Remains in Force

IV Focus of Research

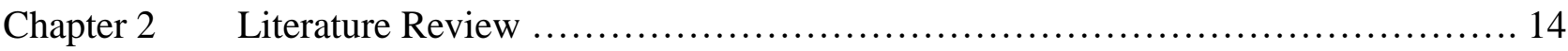

I Introduction

II Legislative Process

III Legal Regimes and Self-Determination

IV Petitions

V Treaty of Waitangi Settlements

VI Justice

VII Summary

Chapter 3 Legal Theory and Methodology

I Legal Theory
A Orthodox Position
B Llewellyn's “Law-Jobs” Theory
C Critical Perspectives
D Summary

II Methodology
A Scope and Limitations
B Raw Data
C Mixed-Methods Approach
D Conclusions and Perspectives

Chapter 4 Enacting Māori Purposes Acts

I Purpose of Chapter

II Origins of Legislative Process

III Process from 1931
A Focus
B Meaning of "Washing-Up"
1 End of session measure 


\begin{tabular}{|c|c|}
\hline \multicolumn{2}{|c|}{ Passage through House of Representatives } \\
\hline 1 & Pattern prior to mid-1980s \\
\hline 2 & Changes in process from 1984 \\
\hline 3 & Dissatisfaction with timeframes \\
\hline 4 & Debates \\
\hline 5 & The Committee \\
\hline 6 & Consultation with Māori \\
\hline
\end{tabular}

IV Conclusions

Chapter 5 Government Machinery, Policy and Amendments

I Introduction

II Machinery and Minor Provisions

III Questioning the "Washing-Up" Characterisation

A Native Purposes Act 1943

B Adoptions, Succession and Customary Marriage

IV Significant Government Policy

A Establishment of Māori Trusts

B Māori Incorporations

1 Rights of appeal

2 Introduction of investigations

3 Responses to Māori Affairs Amendment Acts

V Conclusions

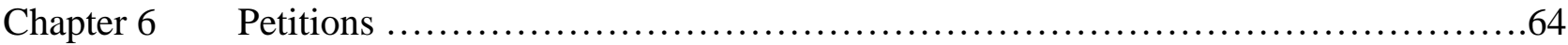

I Overview

II Process

III Recommendations for Favourable Consideration

A Petition of Taite Te Tomo

B Petitions Relating to Te Karae leases

C Palmerston North Reserves

IV Recommendations for Consideration

A Estate of Teo Tipene

B Petition of Ngahuia Beasley

V Petitions Referred for Inquiry

A Wakapuaka Block

B Petition of Ema Ruihi 
C Wellington Tenths Benefit Fund

VI Conclusions

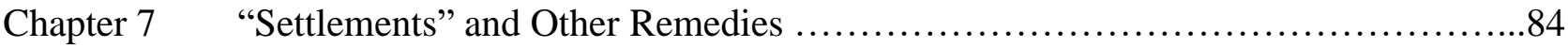

I Overview

II $\quad$ Full and Final Settlements

A Royal Commission Recommendations

1 Jones Commission: Aorangi and Patutahi

2 Pukeroa-Oruawhata claim

$3 \quad$ Sim Commission and surplus lands

B Other Settlements

1 Wairahi

2 Ohinemuri and Omarunui

3 Awhitu

III Other Remedies

A Return of Land

1 Ōwhāoko gift blocks

2 Arahura River bed

B Public Works Act Compensation

1 Whaiti-Kuranui

IV Conclusions

Chapter $8 \quad$ Special Governance Arrangements ............................................104

I Introduction

II An Inspirational Example: Wi Pere Trust

III Protecting Exclusive Rights: Lake Rotoaira

IV Hybrid Governance Structures

A Poho-O-Rawiri Marae

B Other Examples

V Returning Land to Māori Control

A Kaiapoi Pā

B Mangatu Incorporation

VI The Role of Petitions: Pukepuke Tangiora Estate

VII Conclusions

Chapter 9 Conclusions

I "Washing-Up" and Legislative Process 
II The Work of Māori Purposes Acts

A Machinery, Amendments and Policy

B Special Governance Arrangements

C Petitions and Legislative Responses

D Settlements and Remedial Provisions

III Final Observations

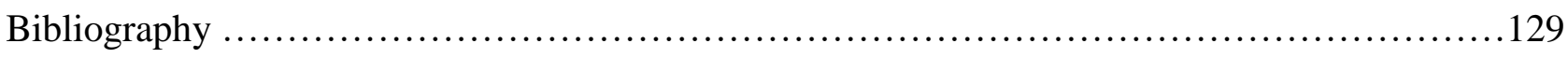




\section{Abstract}

Māori Purposes Bills were commonly described in Parliament's debating chamber as "washing-up” bills, which suggested they were considered to be of little importance. This research challenges that perspective.

The research explores Māori Purposes Acts as a body of law, beginning in 1931. It considers the content of the legislation, the legislative process and the role of Māori Purposes Acts within the legislative framework. The research examines policy provisions and amendments, the petitions process facilitated by the legislation, special governance arrangements, and remedial provisions including settlements with the Crown.

The research incorporates quantitative analysis, but due to the variability of the provisions contained in the legislation, a predominantly qualitative approach is used to consider the nature of the Acts. The research operates within an orthodox legal paradigm and Karl Llewellyn's "law-jobs" theory is used as an analytical framework to identify common themes, draw out the purposes of the legislation and understand its role in New Zealand's legal system. Critical race and post-colonial theoretical perspectives are acknowledged but are not central to the research. The research also considers whether Māori Purposes Acts delivered justice for Māori prior to the modern Treaty of Waitangi settlements process.

The research concludes the washing-up characterisation was often inaccurate. The research found Māori Purposes Acts were used as a mechanism to provide Māori with relief from and remedies for particular problems, which were often raised by petition to Parliament, and remedies gave effect to recommendations of the Māori Affairs Committee and Royal Commissions. Some remedies were expressed as settlements of Māori grievances against the Crown, which preceded modern Treaty of Waitangi settlements. The legislation was used to maintain the legislative framework governing Māori land ownership and Māori communities, to introduce new policies and fill policy gaps, and to create special exceptions to the legislative framework including special governance provisions.

The research provides evidence of the poor fit between the restrictive legislative framework governing Māori lives and Māori needs, and it demonstrates the inability of New Zealand's legal system to deliver justice for Māori. Although many provisions attempted to ameliorate inequities, correct mistakes and resolve disputes, provisions often fell short of meeting the criteria for justice and are best described as taking important steps towards justice. 


\section{Chapter 1: Introduction}

\section{Origins of the Legislation}

Māori Purposes Acts developed from a series of earlier enactments known as the Native Land Amendment and Native Land Claims Adjustment Acts, which as the title suggests, were a combination of amendments to Native land laws and provisions dealing with Māori claims. Prior to 1915 legislative amendments and claims provisions dealing with Māori petitions, claims and disputes were usually addressed in separate legislation. ${ }^{1}$ The consistent amalgamation of amendment and claims provisions in one enactment began in 1915 during World War I as a matter of convenience, and by the time the first Māori Purposes Act was enacted in 1931, amalgamation of the provisions had become an established process. The distinction between amendments and claims provisions is to some extent preserved in current Standing Orders of the House of Representatives. ${ }^{2}$

The Māori Purposes Acts were initially called "Native Purposes Acts", a title chosen in 1931 because no other term could be identified that would cover the "special provisions" dealing with the wide range of subject matters in the Bill. ${ }^{3}$ The name of the legislation was changed in 1947 when the term "Native" was replaced with "Maori" throughout New Zealand legislation. ${ }^{4}$

During the legislative process, Māori Purposes Bills were regularly described in Parliament as "washingup" bills, a non-technical description that derived from Native Land Claims Adjustment Acts, which conveyed expectations as to content and suggested bills did not warrant much debate in the House of Representatives. For many decades little interest was demonstrated by Members of the House in the

$1 \quad$ See Maori Land Laws Amendment Acts of 1903 and 1908, Native Land Amendment Acts of 1912, 1913 and 1914, and Native Land Claims Adjustment Acts of 1910, 1911, 1913 and 1914. The Native Land Claims Adjustment and Laws Amendment Act 1901 and Maori Land Claims Adjustment and Laws Amendment Acts of 1904 , 1906 and 1907 demonstrate experiments with combination Acts.

2 Standing Orders of the House of Representatives 2017, SO 262(1)(d)(i) and (ii) separating amendments from authorisations, transfers and validations in respect of Māori land and property.

(20 October 1931) 230 NZPD 559.

See below n 277. This thesis refers to Native and Māori Purposes Acts by their titles as enacted, although the term Māori Purposes Acts is used generally. Macrons are used in Māori words in accordance with Geoff McLay, Christopher Murray and Jonathan Orpin New Zealand Law Style Guide (2 ${ }^{\text {nd }}$ ed, Thomson Reuters, Wellington, 2011) at 1-2, except where original names or citations are respected. Additional guidance for Māori names is drawn from sources such as Treaty settlement and Waitangi Tribunal documentation. See below n 10. 
content of Māori Purposes Bills, and the House relied heavily on the Māori Affairs Committee to review the Bills. ${ }^{5}$

\section{Content and Trends}

From 1931 until the mid-1980s at least one Māori Purposes Act was enacted every year, resulting in 63 Māori Purposes Acts comprising more than one thousand legislative provisions, plus schedules.

The Native Purposes Act 1931 was a large Act that consolidated earlier Native Land Amendment and Native Land Claims Adjustment Acts, together with various separate amending and claims Acts. ${ }^{6}$ The 1931 Act consolidated provisions that established native and scenic reserves, parks, pā and native townships. ${ }^{7}$ The Act contained provisions that provided for administrative boards and bodies, including those established for preserving Māori arts and crafts and ethnological research, ${ }^{8}$ and the earliest Māori trust boards established for the purpose of receiving settlement monies from the Crown. ${ }^{9}$ The Act also consolidated provisions that vested land in Māori, authorised the Native Land Court to exercise jurisdiction in particular cases, authorised and validated transactions, and addressed Māori claims. ${ }^{10}$

Māori Purposes Acts have since been much smaller in size than the consolidating Act, and the size, nature, and composition of Māori Purposes Acts has changed over time as indicated in Figure 1 below. The significant reduction in the number and size of Māori Purposes Acts from the mid-1980s was the result of a change in legislative process. ${ }^{11}$ The Māori Purposes Act 2017 defies this trend towards smaller Māori Purposes Acts, and is the largest Māori Purposes Act enacted since 1976. ${ }^{12}$ The small size of a Māori Purposes Act is not a reliable indication of the significance of the legislation's contents as

\footnotetext{
5 The Māori Affairs Committee, originally the Native Affairs Committee, is one of New Zealand's oldest select committees: see John E Martin The House: New Zealand's House of Representatives 1854-2004 (Dunmore Press, Palmerston North, 2004) at 56 and EP Angus "Select Committees of the House of Representatives, New Zealand" (MA Thesis, Victoria University College, 1951) at 6-21. References to "the Committee" in this thesis are references to the Native/Māori Affairs Select Committee.

$6 \quad$ Native Purposes Act 1931, s 118 and Schedule.

$7 \quad$ Native Purposes Act 1931, Pts I, II, and III and ss 59, 62 and 66.

$8 \quad$ Native Purposes Act 1931, ss 47 and 48.

$9 \quad$ Native Purposes Act 1931, s 51-53 and ss 54-56.

10 The Native Land Court was renamed the Maori Land Court in 1947, which is now spelt as Māori Land Court. References to the Court in this thesis are to the Native Land Court or Māori Land Court as appropriate for the time period, unless the context suggests another Court is referred to. Generic references are to the Māori Land Court.

$11 \quad$ See chapter 4.

12 See chapter 8.
} 
illustrated by the Maori Purposes Act 1973, which extended annual payments to Ngāi Tahu in perpetuity. $^{13}$

"Claims" provisions dominated the legislation from the 1930s until the 1950s, which reflected the number of Māori petitions to Parliament. Claims provisions were legislative responses to Māori petitions to Parliament raising claims and grievances against the Crown or problems for which there was no legal remedy. These provisions were remedial in the sense that many provisions attempted to correct mistakes or ameliorate unfair consequences for Māori. Some provisions purported to remedy long-standing Māori grievances against the Crown with settlements expressed to be full and final. ${ }^{14}$

From the 1960s Māori Purposes Acts were predominantly comprised of amendments to existing legislation. Māori Purposes Acts did not generally implement broad, cohesive policies, although there were a few exceptions where the legislation was used to effect larger-scale policy changes or introduce significant new policy, particularly in the 1940s and 1950s. Within the Māori legislative framework specific amending Acts often effected larger-scale policy reforms, ${ }^{15}$ whereas Māori Purposes Acts were typically used to make regular, smaller-scale policy changes. Those changes included introducing new policy and extending or amending existing provisions. Māori Purposes Acts regularly amended the principal land legislation, most notably the Native Land Act 1931 and the Maori Affairs Act 1953. Māori Purposes Acts also amended a range of other Māori legislation such as that governing the office of the Māori Trustee, Māori trust boards and affecting Māori communities. ${ }^{16}$ When Māori Purposes Acts did implement significant government policy, use of the term "washing-up" during the legislative process was often qualified by an acknowledgement that a particular Act contained important or significant provisions. $^{17}$

Many claims provisions dealt with private matters, and there were a small number of Māori Purposes Acts that almost exclusively dealt with private matters, putting in place or adjusting special governance arrangements at the request of Māori. ${ }^{18}$

The changes in content and size of Māori Purposes Acts are depicted in Figure 1 below.

\footnotetext{
See below nn 485-486.

See chapter 7.

See Native Land Amendment Acts of 1932 and 1936 and Maori Affairs Amendment Acts of 1962, 1967 and 1974.

See chapter 5 .

See nn 169 and 170.

See chapter 8 .
} 
Figure 1: Size and content of Māori Purposes Acts

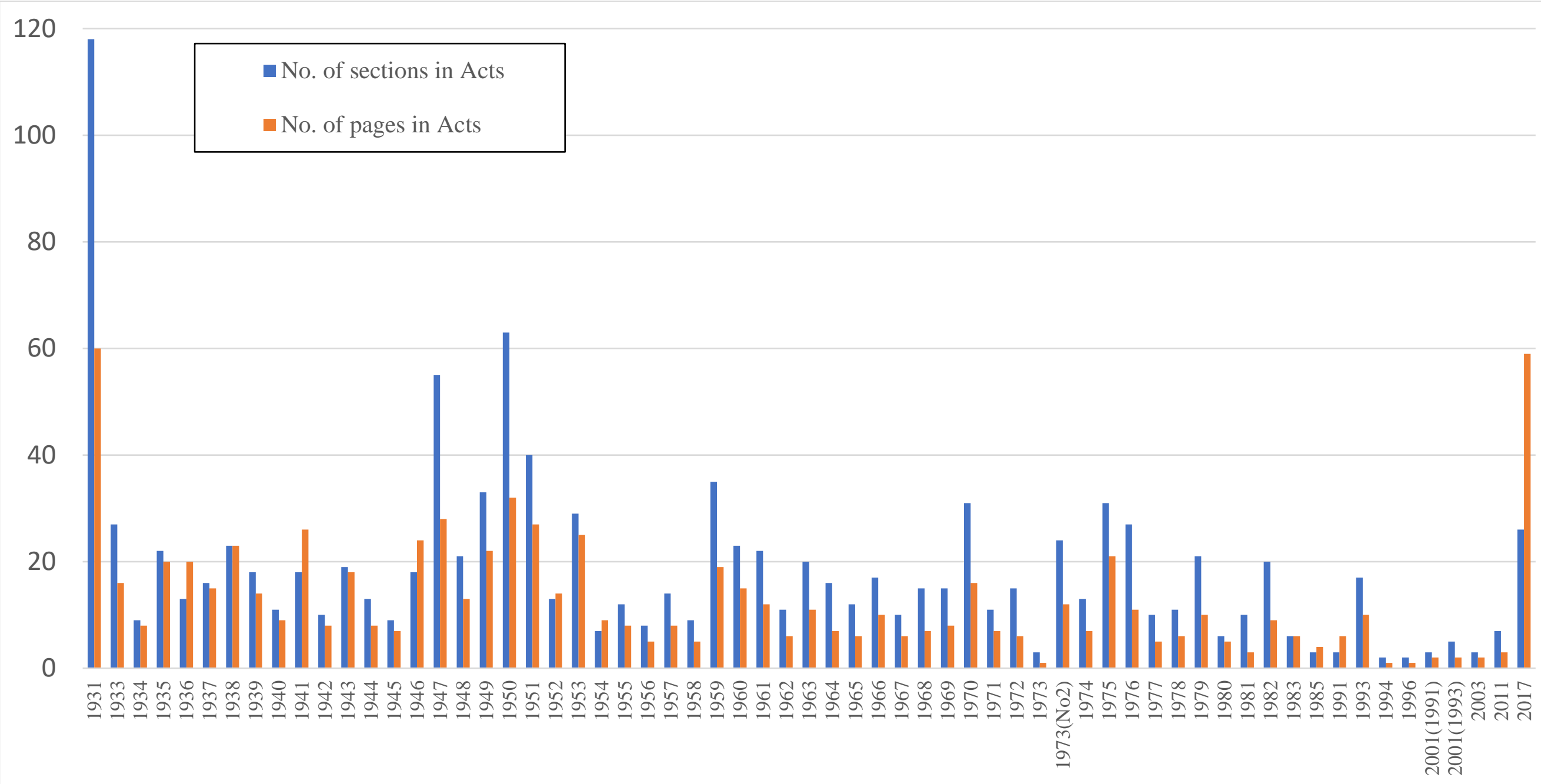


New policy and amendment provisions often sat within Māori Purposes Acts to be read alongside principal legislation, forming part of the enduring substance of Māori Purposes legislation. ${ }^{19}$ Claims provisions and special governance provisions, which were usually new provisions, also formed part of the enduring substance of the legislation. Other amendments implemented direct changes to the text of existing legislation, ${ }^{20}$ and although these provisions often implemented important changes, they did not contribute to the enduring substance of Māori Purposes Acts. These provisions were spent and rendered redundant once the amendment was effected. ${ }^{21}$

Māori Purposes Bills were not formally regulated until 1996 when rules governing omnibus bills were introduced. ${ }^{22}$ Comparisons can be drawn between the functions of some remedial or "claims" provisions in Māori Purposes Acts with provisions in Reserves and other Lands Disposal Acts, another type of "washing-up" or omnibus bill. Both legislative devices contained clauses providing for authorisations, transfers and validations, and rectified errors, in respect of land and property. Māori Purposes Acts dealt with Māori land and property, whereas Reserves and other Lands Disposal Acts dealt with Crown land, reserves and other land held for public or private purposes. ${ }^{23}$ A comparison of the two types of legislation between 1931 and 2017 reveals legislation of a similar frequency and comparable size, and that both Acts have ceased to be passed annually from the mid-1980s. Few direct comparisons can be made between the amending functions of Māori Purposes Acts and Statutes Amendment Acts or Bills, which have encompassed a wider range of subject matters and have typically been much larger than Māori Purposes Acts or Bills. ${ }^{24}$ Māori Purposes Bills remain unique in comparison with other omnibus bills because they are still permitted to include provisions concerning Māori land and trusts that would now require private legislation. ${ }^{25}$

19 This drafting style known as "non-textual": RI Carter Burrows and Carter Statute Law in New Zealand (5 $5^{\text {th }}$ ed, Lexis Nexis, Wellington, 2015) at 672.

20 This drafting style is known as "textual", see above $n$.

21 For "spent" provisions see above n 19, at 645-646.

22 Below nn 145, 149-150.

23 Standing Orders of the House of Representatives 2017, SO 262(1)(d)(ii) and (e)(i). In 1939 the Native Purposes Bill was described as being “on all fours with the Reserves and other Lands Disposal Bill” but dealt with Native lands: (22 September 1939) 256 NZPD 287. See also (10 October 1940) 258 NZPD 215.

24 Standing Orders, above n, SO 262(1)(f). This assessment is based on a comparison of Statutes Amendment Bills and Māori Purposes Bills between 1931 and 2017. See also Mary Harris and David Wilson (eds) McGee Parliamentary Practice in New Zealand (4 ${ }^{\text {th }}$ ed, Oratia Books, Auckland, 2017) at 376-377.

25 Harris and Wilson (eds), above n, at 375 and (9 December 1918) 183 NZPD 1007-1014. In 2016 the Speaker of the House ruled "a Māori Purposes Bill is a special kind of omnibus bill ... it allows a broader range of amendments than those permitted for most other types of omnibus bills, provided they relate to Māori affairs": Speaker's Ruling (12 October 2016) 717 NZPD 14213-14214. 


\section{What Remains in Force}

Te Puni Kōkiri states that it is responsible for administering 71 Acts, 43 of which are Māori Purposes Acts. ${ }^{26}$ The provisions of Māori Purposes Acts that remain in force and operative are claims provisions that contain governance arrangements, together with special governance arrangements of a private nature, some of which trace back to the Native Purposes Act $1931 .{ }^{27}$

Provisions implementing new policy or amending existing legislation were usually repealed when principal land legislation was reformed, and policy provisions in Māori Purposes Acts were either absorbed within new principal legislation or discarded. ${ }^{28}$ Provisions were also repealed when a general legislative framework was introduced to provide for special matters previously dealt with in Māori Purposes Acts, as illustrated by the Māori Trust Boards Act 1955 which established a general framework for Māori trust boards, incorporating boards previously provided for in Māori Purposes Acts. ${ }^{29}$ The Maori Purposes Act 1956 repealed many spent claims provisions because compensation had been paid, appeals or rehearings completed, or the return of land effected. ${ }^{30}$

There are a number of Māori Purposes Acts that remain on the statute book in bare form, where provisions have been repealed expressly or impliedly at various times, leaving only the short title and spent provisions to remain behind. ${ }^{31}$

\section{Focus of Research}

Māori Purposes Acts have never been the subject of substantive analysis and references to Māori Purposes Acts in literature have tended to be peripheral or confined to legal citation.

See <http://www.tpk.govt.nz/en/mo-te-puni-kokiri/what-we-do/legislation>. The name of the government department responsible for Māori affairs changed many times between 1931 and 2017, from "Native Department" in the 1930s, to "Department of Maori Affairs" from 1947, and finally "Te Puni Kōkiri" from 1992: see GV Butterworth and HR Young Maori Affairs: A Department and the People Who Made It (Government Printer, Wellington, 1990). Reference to "the Department" in this thesis encompasses all iterations.

$27 \quad$ See chapter 8.

28 See for example Maori Affairs Act 1953, s 473 and Schedule and Te Ture Whenua Maori Act 1993, s 362 and Second Schedule.

29 Maori Trust Boards Act 1955, Pt I. See also Maori Trustee Act 1953, s 53 and Schedule.

30 Maori Purposes Act 1956, s 6 and Schedule.

31 See Maori Purposes Acts 1955, 1957, 1958, 1960, 1965, 1968, 1971, 1977, 1981, 1982, 1994, and in 2001 and 2003: <http://www.nzlii.org/nz/legis/consol_act/> and <http://www.legislation.govt.nz> (with 'amendment' filter applied). As many Māori Purposes Acts have been repealed, along with other legislation referred to in this thesis, I do not note the repeal of each Act. 
The focus of this research is to examine Māori Purposes Acts to understand the key functions the legislation fulfilled, and to critically assess the context and effect of those provisions and procedures. Despite the variable nature of Māori Purposes Acts over time, there are common themes and purposes running through the legislation, which the research will focus on.

There have been contrasting views of the legislation, ranging from the predominant perception the legislation contained inconsequential provisions, to views the legislation responded positively to Māori needs, and some acknowledgements the legislation and legislative process has resulted in injustices.

The fundamental question the research seeks to answer is whether Māori Purposes Acts, most commonly dismissed as "washing-up" measures, in fact contained important processes, policies and provisions that have been underestimated, misinterpreted or misrepresented. In considering this question, the research will draw conclusions about the significance, contribution and role of Māori Purposes Acts within New Zealand's legal framework. I conclude the legislation contained important provisions and processes not revealed by the "washing-up" characterisation. 


\section{Chapter 2: Literature Review}

\section{Introduction}

Consideration of provisions in Māori Purposes Acts in literature has commonly been incidental to another purpose, rather than considering the substance and content of the legislation. Even literature directly considering "washing-up" or omnibus bills has omitted consideration of Māori Purposes Bills. ${ }^{32}$ A wide variety of literature is potentially relevant to the subject matter of Māori Purposes Acts because the legislation has been used to amend a variety of enactments governing Māori life and property and to address Māori claims. The research will draw upon and contribute to literature on subjects such as petitions to Parliament, Māori claims and Treaty of Waitangi settlements, jurisprudence of the Māori Land Court, and legislative process in New Zealand.

\section{Legislative Process}

Legislative process should ensure that proposed legislation is necessary and "fit for purpose", and each stage in the House of Representatives is intended to achieve a particular deliberative task. ${ }^{33}$

Some legal scholars have questioned the effectiveness of debate within New Zealand's legislative process. Jeremy Waldron has criticised the lack of checks and balances in New Zealand's legislative system in comparison with other jurisdictions. ${ }^{34}$ Waldron argues that "open and wide-ranging debate" is an important component of legislative scrutiny, but there is no genuine debate in New Zealand. ${ }^{35}$ The Rt Hon Sir Geoffrey Palmer agrees that Parliamentary debate has "lost value" in New Zealand and has little impact on the content of legislation, with limited examination of the technical content of bills. ${ }^{36}$

32 For example, see HN Dollimore "New Zealand "Washing-Up" Bills" (1968) 37 The Table 26 and George Tanner "Confronting the Process of Statute-Making" in Rick Bigwood (ed) The Statute: Making and Meaning (Lexis Nexis, Wellington, 2004) 49 at 106.

33 David McGee "Concerning Legislative Process" (2007) 11 Otago LR 417 at 421, Hamish McQueen "Parliamentary Business: A Critical Review of Parliament's Role in New Zealand's Law-Making Process" (2010) 16 Auckland UL Rev 1 at 3-4, and Harris and Wilson, above n 24, ch 26.

34 Jeremy Waldron "Parliamentary Recklessness" [2008] NZLJ 417.

35 Jeremy Waldron "Parliamentary Recklessness - II" [2008] NZLJ 458 at 460.

36 Geoffrey Palmer "Law-Making in New Zealand: Is there a Better Way?" (2014) 22 Wai L Rev 1 at 25-26, and 3940. 
Many academics view New Zealand's select committee process as a strong feature of our legislative process, one that is crucial to the quality of Parliamentary scrutiny of bills. ${ }^{37}$ Select committees are the source of most amendments to bills, which tend to improve the quality of a bill rather than changing policy. ${ }^{38}$ Waldron argues the select committee process is not a sufficient safeguard alone to ensure adequate scrutiny of proposed legislation. ${ }^{39}$ In contrast, Hamish McQueen has suggested the small size of the select committee forum lends itself to collegiality and specialisation. ${ }^{40}$ In a 1950 study of select committees in New Zealand, EP Angus also argued that select committees encouraged full and frank discussion and were the best forum for technical examination of bills. ${ }^{41}$ However, flaws and weaknesses in the select committee process have been identified, including the potential for governments to control select committees or undermine their processes, allowing insufficient time to consider and consult on legislative measures. ${ }^{42}$

A prevalent criticism of New Zealand's legislative process has been the speed with which legislation is passed. Geoffrey Palmer has attributed New Zealand's tendency to push legislation through the House quickly to our short electoral cycle and political pressure on governments. ${ }^{43}$ The use of urgency to expedite the passage of legislation has been identified as a particular problem because in many instances the process is invoked to pass measures that are not genuinely urgent. ${ }^{44}$ Omnibus bills have been recognised as a particular device designed to "fast-track" legislation. ${ }^{45}$ Concerns about misuse of omnibus bills prompted formal controls to be introduced in 1996, although Māori Purposes Bills were not identified as being problematic. ${ }^{46}$ Introduction of the Mixed Member Proportionate electoral system

37 For example, see Ryan Malone Rebalancing the Constitution: The Challenge of Government Law-making under MMP (Institute of Policy Studies, Victoria University of Wellington, Wellington, 2008) ch 7 and Philip A Joseph Constitutional and Administrative Law in New Zealand ( $4^{\text {th }}$ ed, Brookers, Wellington, 2014) at 342-343.

McGee, above n 33, at 424-425.

Waldron, above n 35, at 458.

McQueen, above n 33, at 9.

Angus, above n 5, at 1-3.

McQueen, above n 33, at 11 and 18-21; Palmer, above n 36, at 20; JF Burrows and PA Joseph "Parliamentary Law Making" [1990] NZLJ 306 at 307-308.

Palmer, above n 36, at 6 and Geoffrey Palmer Unbridled Power: An Interpretation of New Zealand's Constitution and Government ( $2^{\text {nd }}$ ed, Oxford University Press, Auckland, 1987) at 140.

Claudia Geiringer, Polly Higbee and Elizabeth McLeay What's the Hurry? Urgency in the New Zealand Legislative Process 1987-2010 (Victoria University Press, Wellington, 2011) and McQueen, above n 33, at 19.

Harris and Wilson, above n 24, at 370; McGee, above n 33, at 426-429; and Carter, above n 19, at 78-81. Standing Orders Committee "Report of the Standing Orders Committee: Review of Standing Orders" [1993-1996] XLIII AJHR I18A at 49-51. 
(MMP) may have slowed down the passage of legislation in New Zealand, but this is not universally agreed. ${ }^{47}$

A further criticism made of New Zealand's legislative process by Palmer and George Tanner is the incoherence of our law-making, with constant amendments to large Acts that put at risk the principles and coherence of the original statutes, reflecting poor policy design and deliberative processes. ${ }^{48}$

Tanner has also written of the "intensely political" process underpinning the content and passage of legislation, that legislation requires negotiation and the balancing of contrasting beliefs and prejudices. ${ }^{49}$ The political difficulties that Māori have faced in Parliament, with limited representation prior to the introduction of MMP, are acknowledged in literature. ${ }^{50}$

I will consider these key themes in the context of the enactment of Māori Purposes Acts and whether these strengths and criticisms are evident.

\section{Legal Regimes and Self-Determination}

A range of literature addresses the legislative regimes that have impacted on the lives of Māori, but I focus here on several texts which have particularly strong connections with the research.

PG McHugh has written about the introduction of legislative regimes in colonial settlements that regulated aboriginal life and establishing European governance structures. In New Zealand, legislation transformed and controlled Māori land ownership and regulated important aspects of Māori society including Māori identity, marriage and family relationships, with inconsistent legal recognition of customary adoptions and marriage. ${ }^{51}$ McHugh considers that law served colonial ideology, effected by

47 Compare the findings of Malone, above n 37, ch 9 and Tanner, above n 32, at 104-105 with McGee, above n 33, at 419-420.

48 Palmer, above n 36, at 3-4 and 13-14; and Tanner, above n 32, at 80-81.

49 Tanner, above n 32, at 52-53. See also Geoffrey Palmer New Zealand's Constitution in Crisis: Reforming our Political System (John McIndoe, Dunedin, 1992) at 25.

50

For example see Maria Bargh (ed) Māori and Parliament: Diverse Strategies and Compromises (Huia Publishers, Wellington, 2010). See also John Wilson “The Origins of Maori Seats” <https://www.parliament.nz/en/pb/researchpapers/document/00PLLawRP03141/origins-of-the-māori-seats\#RelatedAnchor>.

51

PG McHugh Aboriginal Societies and the Common law: A History of Sovereignty, Status, and Self-Determination (Oxford University Press, Oxford, 2004) at 49, 264-276 and 346-348. Richard Hill has also written on this subject: see Richard S Hill Maori and the State: Crown-Maori Relations in New Zealand/Aoteoroa, 1950-2000 (Victoria University Press, Wellington, 2009) at 31-38 and 105. 
a "continual and messy process of invention, reinvention, and improvisation". ${ }^{52} \mathrm{McHugh}$ examines how legal regimes have reflected assimilationist policies after World War II, and later, accommodated Māori self-determination. These themes are evident in amendment and policy provisions within Māori Purposes Acts.

Richard Boast has written extensively about the detrimental effects of the legislative framework governing ownership of Māori land, which imposed individual ownership upon "fluid and complicated customary tenures" for the purpose, or with the effect, of facilitating alienation of Māori land. ${ }^{53}$ There have been many unwanted or unforeseen consequences resulting from imposition of this legal framework including disruption of customary succession and fragmentation of ownership. These consequences are evident in most remedial provisions in Māori Purposes Acts. These problems prompted reliance on devices such as trusts and Māori incorporations to manage large numbers of owners on Māori land titles, ${ }^{54}$ devices that have been the subject of policy changes and special governance arrangements in the legislation.

The concept of self-determination is relevant to many provisions in Māori Purposes Acts. Mason Durie has written about what the concept of Māori self-determination encompasses, which has different dimensions in different contexts. Durie describes the goal as essentially about Māori advancement, which is grounded in practical outcomes. Perhaps most relevant to this research is Māori desire for improved self-management, strengthened "economic standing, social well-being and cultural identity", "decision-making that reflects Maori realities and aspirations", and independence from the state. ${ }^{55}$ These aspirations are best reflected in special governance provisions sought by Māori and contained in Māori Purposes Acts, and are also reflected in settlement provisions contained in the legislation.

$52 \quad$ McHugh, above n, at 7.

53 Richard Boast Buying the Land, Selling the Land: Governments and Maori Land in the North Island 1865-1921 (Victoria University Press, Wellington, 2008) at 117-119 and ch 2, and Richard Boast, Andrew Eruiti, Doug McPhail and Norman F Smith Māori Land Law (2 ${ }^{\text {nd }}$ ed, Lexis Nexis, Wellington, 2004) at 117-119 and ch 4.

$54 \quad$ Boast and others, above n, at 107-108.

55 Mason Durie Te Mana, Te Kāwanatanga: The Politics of Māori Self-Determination (Oxford University Press, Auckland, 1998), at 4-6. 


\section{Petitions}

The right to petition Parliament is a "fundamental principle" of New Zealand's constitution, one which "goes back as far as Parliament itself". ${ }^{56}$ It was originally a means by which royal justice supplemented that of the courts, based on fairness and equity. ${ }^{57}$

A number of authors writing about Māori claims and settlements recognise that Māori were forced to resort to petitioning Parliament to seek redress for grievances, and that petitions were often part of a complex pathway to ultimate resolution of a grievance. ${ }^{58}$ Māori were unable to hold the Crown legally accountable for its actions largely due to the decision of Wi Parata $v$ Bishop of Wellington, which treated dealings between the Crown and Māori involving "cession of their title" as acts of state that were not examinable in the Courts. ${ }^{59}$ This approach was incorporated in legislation in respect of customary title. ${ }^{60}$ The ability of any subject to take proceedings against the Crown was also restricted, initially at common law and then under statute. ${ }^{61}$ Proceedings under statute were confined to claims based on contracts and wrongs relating to public works, and claims had to be brought within a short period. ${ }^{62}$ This framework left Māori without legal remedies for ambiguities in agreements with the Crown relating to land and errors made by officials, and made no allowance for belated discovery of problems. The outcome was, as David V Williams has suggested, that petitions became "the primary vehicle to seek redress." ${ }^{3}$ The Crown's liability in contract and tort was expanded from 1910, but remained subject to key exceptions, and longer limitation periods were not introduced until $1950 .{ }^{64}$

56 Geoffrey Palmer and Matthew Palmer Bridled Power: New Zealand Government under MMP (3 ${ }^{\text {rd }}$ ed, Oxford University Press, Auckland, 1997) at 137 and 221-224.

Peter Spiller, Jeremy Finn and Richard Boast A New Zealand Legal History (2 $2^{\text {nd }}$ ed, Brookers, Wellington, 2001) at 17-19.

Michael Belgrave "Negotiations and settlements" in Nicola R Wheen and Janine Hayward (eds) Treaty of Waitangi Settlements (Bridget Williams Books, Wellington, 2012) 29 at 36-38; Michael Belgrave Historical Frictions: Maori Claims \& Reinvented Histories (Auckland University Press, Auckland, 2005) at 23 and 27-28; Palmer, above n 49, at 74; Alan Ward A Show of Justice: Racial Amalgamation in Nineteenth Century New Zealand (Auckland University Press, Auckland, 1973) at 271; and David V Williams A Simple Nullity? The Wi Parata Case in New Zealand law \& history (Auckland University Press, Auckland, 2011) at 235-237. Wi Parata v Bishop of Wellington (1877) 3 NZ Jur (NS) SC 72; (1877) 1 NZLRLC 14 (SC) at 19. See Williams, above n.

PG McHugh "The legal basis for Maori claims against the Crown" (1988) 18 VUWLR 1 at 5-6 discussing s 155 of the Maori Affairs Act 1953, preceded by the Native Land Act 1909, s 84 and Native Land Act 1931, s 112. See "The Crown Proceedings Act 1950 (I)" (1952) 28 NZLJ 17; "The Crown Proceedings Act 1950 (II)" (1952) 28 NZLJ 49 and "The Crown Proceedings Act 1950 (III)" (1952) 28 NZLJ 65. 
The effectiveness of the petitions process has been questioned. Richard Boast has described the process as time-consuming and "cumbersome", ${ }^{65}$ and Alan Ward concluded that good outcomes were limited to "a variety of small questions". ${ }^{66}$ The close relationship between petitions and provisions in the Māori Purposes Acts has been identified, and further research into the area has been suggested. ${ }^{67}$

A research paper by Guy Finny examined Māori petitions before the Committee between 1871 and $1900 .{ }^{68}$ Finny identified that petitions predominantly related to Māori land issues, which he considered a reflection of the "broken" legal system governing Māori land. Finny concluded the Committee was not "an effective organ for substantive justice" and legislative responses were generally ineffective in achieving real change, but the Committee did function as an "accountability mechanism". 69

I will examine the petitions process and its outcomes through the lens of the Māori Purposes Acts, and will consider whether these conclusions are sustained within the period of this research.

\section{Treaty of Waitangi Settlements}

Māori Purposes Acts were government legislation containing policy and remedial provisions responding to Māori needs and grievances, including settlements. It is important to consider the how the Crown's obligations under the Treaty may have influenced, or been reflected in, the content of the legislation.

Academic literature examines the manner in which the Treaty was entered into from an historical perspective, the most prominent work arguably being that of Claudia Orange. ${ }^{70}$ Orange considers the Treaty has always been a "touchstone" for Māori protest and grievances, ${ }^{71}$ although this interpretation has been questioned by Andrew Sharp who suggests Māori interest in the Treaty developed from the 1970s and 1980s. ${ }^{72}$

\footnotetext{
65 RP Boast "Judge Acheson, The Native Land Court, and the Crown: A Report to the Waitangi Tribunal” (Wai 1040, October 2016) at 9-10.

$66 \quad$ Ward, above n 58.

$67 \quad$ Boast, above n 65, and Williams, above n 58.

68 Guy Finny "New Zealand's Forgotten Appellate Court? The Native Affairs Committee, Petitions and Maori Land: 1871-1900" (LLB (Hons) Dissertation, Victoria University of Wellington, 2013) at 9-12.

$69 \quad$ Above n, at 5 and 18-20. See also Martin, above n 5, at 56.

70 Claudia Orange The Treaty of Waitangi (Allen \& Unwin, Wellington, 1987).

71 Above n, at 185-186.

72 Andrew Sharp Justice and the Māori: The Philosophy and Practice of Māori Claims in New Zealand since the 1970s ( $2^{\text {nd }}$ ed, Oxford University Press, Auckland, 1997) at 86-88.
} 
There is a significant body of literature examining the changing and developing role of the Treaty within New Zealand's constitution and legal framework. ${ }^{73}$ Matthew Palmer has examined the obligations between Crown and Māori recorded in the Treaty of Waitangi, and considers how interpretation and recognition of the Treaty has evolved over time. ${ }^{74}$ Palmer considers the meaning ascribed to the Treaty by government institutions has been influenced by pragmatic considerations, and concludes the significance of the Treaty "is not fully reflected in its current legal status, which is incoherent, and its legal force, which is inconsistent". ${ }^{75}$ Palmer concludes the traditional position that the Treaty of Waitangi has no legal standing unless it was incorporated into legislation continues to prevail, ${ }^{76}$ despite "greater judicial willingness"77 to rely on the Treaty regardless of the legislative position in the 1980s and 1990s. ${ }^{78}$

The Crown's view and responses to the Treaty of Waitangi have also been considered from a policy perspective. In research on the development of Crown policy in relation to Treaty of Waitangi claims in the "pioneering years" of the 1980s and 1990s, Therese Crocker concluded there was no coherent or developed Crown policy in respect of the Treaty prior to the introduction of the "Principles for Crown Action on the Treaty of Waitangi" in 1989. Crocker attributes the development of Crown policy to the Māori renaissance of the 1970s and jurisprudence of the 1980s. ${ }^{79}$

There is also a body of literature examining Māori claims and the modern Treaty of Waitangi settlements process since the early 1990s. ${ }^{80}$ There is less literature addressing the more sporadic Crown settlements prior to this process, although the Lakes settlements of the 1920s and well-known settlements such as

For example, see Matthew SR Palmer The Treaty of Waitangi in New Zealand's Law and Constitution (Victoria University Press, Wellington, 2008) and FM (Jock) Brookfield Waitangi \& Indigenous Rights: Revolution, Law \& Legitimation ( $2^{\text {nd }}$ ed, Auckland University Press, Auckland, 2006). For a range of perspectives see IH Kawharu (ed) Waitangi: Maori \& Pakeha Perspectives of the Treaty of Waitangi (Oxford University Press, Auckland, 1989) and Michael Belgrave, Merata Kawharu and David Williams (eds) Waitangi Revisited: Perspectives on the Treaty of Waitangi (Oxford University Press, South Melbourne, 2005).

74 Palmer, above n, chs 3-5.

$75 \quad$ Palmer, above $\mathrm{n} 73$, at $152-153$ and 351.

76 Palmer, above $\mathrm{n} 73$, at 168-175 and see also McHugh, above n 51, at 421.

77 McHugh, above $\mathrm{n}$.

$78 \quad$ Above nn 76 and 77.

79 Therese Suzanne Crocker "Settling Treaty Claims: The Formation of Policy on Treaty of Waitangi Claims in the Pioneering Years, 1988 -1998" (PhD Thesis, Victoria University, 2016) 59-64, 68 and see also ch 3.

For example, see Wheen and Hayward, above n 58; Belgrave Historical Frictions, above n 58, Carwyn Jones New Treaty, New Tradition: Reconciling New Zealand and Mãori Law (Victoria University Press, Wellington, 2016); Sharp above n 72; and A Mikaere "Settlement of Treaty Claims: Full and Final or Fatally Flawed" (1997) 17 NZULR 425 . 
Ngāi Tahu have been considered. ${ }^{81}$ Cathy Marr wrote a detailed report on the settlements of the 1940s and 1950s, implementing recommendations and findings of Royal Commissions in the Māori Purposes Acts. $^{82}$ Marr concluded the Crown refused to negotiate these settlements in terms of the Treaty of Waitangi, basing remedies on concepts of "good conscience and equity." 83 Although earlier settlements are considered to have established the model for the modern Treaty settlement process, ${ }^{84}$ they have been distinguished from modern Treaty settlements for a variety of reasons including limited consultation with Māori, inequality of bargaining power, scope of inquiry and terms of settlements, and the extent to which settlements were founded on the Treaty. ${ }^{85}$ It is generally accepted the earlier settlements were inadequate, despite recognition they were genuine attempts to resolve grievances in the acknowledgement that injustices or wrongs had been done, and were intended to be a final resolution of the grievance. ${ }^{86}$ These distinctions do not mean the modern Treaty settlement process is ideal. Questions have been raised about whether the process is fair for Māori, ${ }^{87}$ whether the governance structures Māori are required to establish to receive settlements are culturally appropriate, ${ }^{88}$ and whether modern Treaty settlements will prove more permanent than earlier settlements. ${ }^{89}$

Māori Purposes Acts were enacted in the context of limited recognition of the Treaty of Waitangi within New Zealand's legal system and in the absence of clear Crown policy in respect of the Treaty. The research examines the basis on which the legislation was enacted, considering these themes and conclusions.

See Spiller, Finn and Boast, above n 57; Boast and others, above n 53, at 103-104; and Belgrave "Negotiations and settlements", above n 58, at 42-45 and Historical Frictions, above n 58, ch 4.

Cathy Marr "Crown Policy Towards Major Crown-Iwi Claim Agreements of the 1940s and 1950s: A Preliminary Report for the Treaty of Waitangi Policy Unit" (Stout Centre for New Zealand Studies, Victoria University of Wellington, Wellington, 2010). See also Hill, above n 51, at 215-227 and Richard Hill "Settlements of Major Maori Claims in the 1940s: A Preliminary Historical Investigation" (Department of Justice, Wellington, 1989): <http://www.nzcpr.com/wp-content/uploads/2013/01/Richard-Hills-Report.pdf>.

Marr, above n, at 4.

Belgrave Historical Frictions, above n 58, at 317-320.

See Office of Treaty Settlements, Ka tika à muri, ka tika à mua: Healing the past, building a future. A Guide to Treaty of Waitangi Claims and Negotiations with the Crown (Office of Treaty Settlements, Wellington, 2015) at 14 and 148, Belgrave "Negotiations and settlements", above n 58, at 31-33, Belgrave, Historical Frictions, above n 58 at 317-318, and Crocker, above n 79, at 26-29.

Hill "Settlements of Major Maori Claims", above n 82, at 7-12, and Marr, above n 82, at 9-10.

Crown Forestry Rental Trust Māori Experiences of the Direct Negotiations Process (Crown Forestry Rental Trust, Wellington, 2003): < http://www.cfrt.org.nz/doclibrary/public/thestorehouse/companiondocs/experiences.pdf>, Linda Te Aho "Contemporary Issues in Māori Law and Society: Mana Motuhake, Mana Whenua" (2006) 14 Wai L Rev 102 at 104, Jones, above n 80, ch 4 and Wheen and Hayward (eds), above n 58, especially chs 4, 11 and 12. Jones, above $n 80$.

Mikaere, above n 80. See also Jones, above n 80, at 21. 


\section{Justice}

Andrew Sharp proposed a model of reparative justice in Justice and the Māori that I will use as a framework for considering whether remedial provisions in Māori Purposes Acts, resulting from claims, petitions and advocacy, delivered justice to Māori. ${ }^{90}$

Sharp argues it is impossible to achieve the ideals of justice in a bicultural society because of cultural differences as to behaviour, values, and expectations, making it difficult to define wrongs and decide what justice should be. ${ }^{91}$ Sharp's model frames reparative justice as a "reciprocal exchange", one in which the wrongdoer "repairs" a wrong by restoring the wronged party to his or her original position without securing an advantage and restoring balance. Sharp presents compensation as a "second-best" substitute for reparation. Sharp highlights the difficulties of delivering justice when third parties become caught up in wrongs committed. ${ }^{92}$

Sharp also considers a different form of justice, referred to as distributive justice or social equity, which he acknowledges is difficult to define. Sharp considers that social equity encompasses notions of equality between citizens, such as equal power to act in society, equal access to institutions, equal treatment and Māori independence of Pākehā control, ${ }^{93}$ which could be expressed as self-determination. Where relevant, this framework will guide consideration of policy and special governance provisions that may give expression to the ideal of social equity.

\section{Summary}

Existing literature identifies the strengths and weaknesses of New Zealand's legislative process, the frequency and motivations for Māori petitions to Parliament, the restrictive nature of legal regimes governing Māori, the relevance of the Treaty of Waitangi and considerations of justice. My analysis of the provisions and processes contained within Māori Purposes Acts will consider the key themes and conclusions outlined in this chapter.

\footnotetext{
$90 \quad$ Above $\mathrm{n} 72$.

$91 \quad$ Above n 72, at 34.

92 Above n 72, at 34-35 and ch 6.

93 Above n 72, at 22, 29-30, and 181.
} 


\section{Chapter 3: Legal Theory and Methodology}

\section{Legal Theory}

The purpose of the research is to examine the largely unexplored Māori Purposes Acts and to understand the content of this body of legislation and its role within the New Zealand legislative system and the Māori legislative framework, and in doing so create a representative picture of the legislation. This chapter outlines the legal theory applied and methodology used in this thesis.

\section{A Orthodox Position}

This research paper is located within the orthodox legal paradigm, a phrase used in the context of Treaty jurisprudence, which was described as a negative definition in the sense it meant "not radical". ${ }^{4}$ The phrase has been further explained as including "adherence to the traditional concepts of the rule of law... and unitary Parliamentary sovereignty". ${ }^{95}$ Relevant to this research is acceptance of the authority of Parliament to pass, amend and repeal legislation, and the supremacy of legislation over other sources of law. ${ }^{96}$ The research accepts a positivist view that laws in the Māori Purposes Acts are valid due to their enactment by Parliament, irrespective of whether those laws could be argued to be unreasonable or moral, ${ }^{97}$ though this does not prevent criticism of those laws. Locating this research within the orthodox legal paradigm acknowledges the research does not question the legitimacy of the New Zealand legal system, which a radical academic orientation would. ${ }^{98}$

My examination of Māori petitions and the early settlement provisions contained within Māori Purposes Acts is underpinned by acceptance of the necessity of resolving Māori claims. The status of the Treaty of Waitangi in New Zealand, which underpins Māori claims, is a question that has challenged the New Zealand legal system. ${ }^{99}$ This research assumes what may be now described as an orthodox acceptance

\footnotetext{
94 PG McHugh "Legal Reasoning and the Treaty of Waitangi: Orthodox and Radical Approaches" in Graham Oddie and Roy W Perrett (eds) Justice, Ethics, and New Zealand Society (Oxford University Press, Auckland, 1992) 91 at 91.

95 K Upston-Hooper "Slaying the Leviathan: Critical Jurisprudence and the Treaty of Waitangi" (1998) 28 VUWLR 683 at 689. For Parliamentary sovereignty see Joseph, above n 37, ch 15 and Palmer, above n 49, at 42-44. See also Carter, above $\mathrm{n} 19$, at 19-24.

$97 \quad$ HLA Hart The Concept of Law ( ${ }^{\text {rd }}$ ed, Oxford University Press, Oxford, 2012) at 185.

98 See Ani Mikaere "The Treaty of Waitangi and Recognition of Tikanga Māori” in Belgrave, Kawharu and Williams (eds), above n 73, at 330. For radical perspectives, see below nn 121-123.

$99 \quad$ See McHugh, above n 94, and above nn 73-78.
} 
of the necessity of settling outstanding Māori claims and expectations whether pursuant to the Treaty of Waitangi, ${ }^{100}$ the common law of aboriginal rights, ${ }^{101}$ or other moral obligation. ${ }^{102}$

B Llewellyn's "Law-Jobs" Theory

Karl Llewellyn's law-jobs framework provides a broad over-arching theoretical framework capable of explaining the multifarious nature of the Māori Purposes Acts.

Llewellyn's law-jobs theory developed from his research into the laws of Cheyenne Indians, ${ }^{103}$ and formed part of the American Realism movement of the early $20^{\text {th }}$ century. Realism challenged the prevailing view that law and legal reasoning was logical, achieving determinate results in the manner of a science. ${ }^{104}$ William Twining, an academic with a particular interest in Llewellyn's theories, has reconsidered his view Llewellyn's theory was useful only as a "tool for functional analysis", 105 reassessing its potential as an analytical theory. ${ }^{106}$ Twining sees potential in the theory's flexibility because it can be applied to any group, and he argues the theory is "value free" in the sense that Llewellyn did not assume that survival of the group was "necessarily desirable" or that conflict was "always undesirable". ${ }^{107}$ While it is certainly possible to apply the theory in a value-free manner, it can also encompass values such as justice, which Llewellyn himself anticipated. ${ }^{108}$

The Crown accepts a moral obligation to resolve historical grievances in accordance with the principles of the Treaty of Waitangi: above n 85, at 6. See also Brookfield, above n 73, at 182, where he accepts settling Māori grievances is essential to legitimating the existing constitutional position.

$101 \quad$ See McHugh, above n 51.

102 See McHugh, above n 94, at 96.

103 KN Llewellyn and E Adamson Hoebel The Cheyenne Way: Conflict and Case Law in Primitive Jurisprudence (University of Oklahoma Press, Oklahoma, 1941) ch IX.

104 See JE Penner and E Melissaris McCoubrey \& White's Textbook on Jurisprudence (5 $5^{\text {th }}$ ed, Oxford University Press, Oxford, 2012) at 123; Marett Leiboff and Mark Thomas Legal Theories: Contexts and Practices ( $2^{\text {nd }}$ ed, Thomson Reuters, Sydney, 2014) at 387; and Raymond Wacks Understanding Jurisprudence: An Introduction to Legal Theory ( $4^{\text {th }}$ ed, Oxford University Press, Oxford, 2015) at 168-171. For the development of the realist movement see William Twining Karl Llewellyn and the Realist Movement ( $2^{\text {nd }}$ ed, Cambridge University Press, Cambridge, 2012), Pt I.

105 Twining, above $\mathrm{n}$, at 182.

106 William Twining General Jurisprudence: Understanding Law from a Global Perspective (Cambridge University Press, Cambridge, 2009) at 106-116 and William Twining "The Idea of Juristic Method: A Tribute to Karl Llewellyn” (1993) 48 U Miami L Rev 119 at 131-134.

107 Twining, General Jurisprudence, above n, at 107 and 132

108 KN Llewellyn "The Normative, the Legal and the Law-Jobs: The Problem of Juristic Method" (1940) 49 Yale L J 1355 at 1391. Leiboff and Thomas have interpreted the theory as incorporating ideals, see above n 104, at 392-394. 
Llewellyn identified three core jobs that law performs to keep a human group functioning, ${ }^{109}$ jobs which play into one another. ${ }^{110}$

Llewellyn referred to the first law-job as the "adjustment of the trouble-case" which included offenses, grievances and disputes. ${ }^{111}$ Llewellyn described problems as typically being of an individual nature, but the cumulative effect of enough "unhealed breaches" had the potential to disrupt the group. The purpose of this law-job was to ensure conflicts and grievances were resolved to preserve the existence of the group. Llewellyn summarised the work performed by this job as "the garage-repair work on the general order of the group when that general order misses fire, or grinds gears, or even threatens total breakdown". ${ }^{112}$ Many provisions in Māori Purposes Acts have been Crown responses to individual troublecases, including not only claims and settlement provisions, but extending to policy and governance provisions.

Llewellyn described the second law-job as the "preventative channeling and shift of orientation" which involved directing human behaviour and attitudes by producing and maintaining an order that sets out expectations and values. Llewellyn contemplated a coherent legal order, one that would anticipate conflict, for example by controlling access to "scarce and desirable" resources. ${ }^{113}$ Trouble-cases responded to and operated on this order. Llewellyn's second law-job encompassed the rechanneling of behaviour and values provided rechanneling was "relatively rare" and changes were clear and "relatively permanent". ${ }^{114}$ Llewellyn acknowledged legal orders cannot capture all aspects of culture but warned "Law must not diverge too far from Custom". ${ }^{115}$ In Māori Purposes Acts this law-job is identifiable primarily in provisions maintaining the existing legal system and those introducing new policy or amending the existing legislative framework, although many such provisions also fall within the troublecase category.

Llewellyn's third law-job was the allocation and exercise of authority within a group, a function that encompassed both institutional devices and legal procedures. Llewellyn acknowledged this law-job

Llewellyn "The Normative, the Legal and the Law-Jobs", above n, at 1373-1400 and Karl N Llewellyn Jurisprudence: Realism in Theory and Practice (University of Chicago Press, Chicago, 1962) ch 15 . See also Twining, General Jurisprudence, above n 106, ch 9 and Twining "The Idea of Juristic Method", above n 106, at 126130.

$110 \quad$ Hoebel and Llewellyn, above n 103, at 297.

111 Llewellyn "The Normative, the Legal and the Law-Jobs", above n 108, at 1375-1376.

$112 \quad$ Above n 108, at 1375.

113 Above n 108, at 1376-1383.

114 Above n 108, at 1377.

$115 \quad$ Above n 108, at 1377 and 1382. 
could be created by the first two law-jobs. ${ }^{116}$ This job is visible in the allocation of jurisdiction within Māori Purposes Acts to deal with petitions and authorise legal proceedings.

Llewellyn considered these three "law-jobs" served two higher or ultimate law-jobs. The first of these higher purposes was what Llewellyn termed the "Net Drive"; the job of integrating, incentivising and directing the group, which he viewed as reflecting the constructive purpose of law. ${ }^{117}$ This job required adjustments to the legal system to recapture balance within the group for its "long-range welfare". Llewellyn considered the ideal of justice could be found in this job, which included fair handling of trouble-cases and social justice for those in need. ${ }^{118}$ Llewellyn acknowledged this job involves making choices and that long-term planning is difficult, leading to tinkering "under the tug and torsion or some feeling for the Whole". ${ }^{119}$ This idea, while vaguely expressed by Llewellyn, resonates with the Crown's approach to Māori policy and resolution of problems, claims and disputes.

Llewellyn's law-jobs framework is, as Twining contemplates, flexible enough to accommodate the variety of legislative interventions contained in Māori Purposes Acts, whether enacted on a principled or ad hoc nature, and it permits consideration of justice and Treaty of Waitangi obligations. Twining also identified that the law-jobs theory, "by going back to fundamentals", requires looking beyond specialised devices or institutions to focus on the "total picture", which again resonates with this research. ${ }^{120}$

\section{Critical Perspectives}

In seeking to understand the realities of the political legislative process, and the effect of that process on the laws enacted, the analysis will at times acknowledge themes drawn from critical race and postcolonialist theoretical perspectives. Post-colonialism developed as an extension to critical race theory, and both perspectives challenge racism in the concepts, institutions, and procedures of the law, recognising the law is not neutral. ${ }^{121}$ In New Zealand these theoretical perspectives have challenged the

\footnotetext{
$116 \quad$ Above $n$ 108, at 1383-1387.

117 Above n 108, at 1387-1391. The fifth law-job involves ensuring methods of law are maintained and improved, which I do not focus on.

118 Above n 108, at 1391.

$119 \quad$ Above n 108, at 1387.

120 Twining, above n 104, at 183.

121 Wacks, above n 104, at 351-354.
} 
"myth-making" or "intellectual dishonesty" 122 that accompanies colonial assumptions of "racial and cultural superiority and inferiority". ${ }^{123}$

\section{Summary}

This research uses Llewellyn's "law-jobs" framework to draw insights about the provisions and processes contained in Māori Purposes Acts. Although my legal theory is predominantly orthodox, it will be mindful of critical legal perspectives.

\section{Methodology}

\section{A Scope and Limitations}

The research begins with the Native Purposes Act 1931 and concludes with the Māori Purposes Act 2017. The research does not consider the Native Land Amendment and Native Land Claims Adjustment Acts, which preceded Māori Purposes Acts, except as consolidated within Māori Purposes Acts, as relevant to case studies, and to explain the origins of the legislative process from 1931. The research begins from the vantage point of Māori Purposes Acts as enacted, then looks back to Māori Purposes Bills and the legislative process. ${ }^{124}$ The research does not examine the content of amending Acts that were divided from Māori Purposes Bills from the mid-1980s.

It is outside the scope of the research to provide a comprehensive analysis of Māori land title issues, Māori legislation, or Māori policy across the time period of the research. However, the research reflects these subjects through the lens of the Māori Purposes Acts.

\footnotetext{
122 See Ani Mikaere Colonising Myths - Maori Realities: He Rukuruku Whakaaro (Huia Publishers, Wellington, 2011) at 133-146 and M Jackson "Colonisation as Myth-Making: A Case Study in Aotearoa" in Greymorning S (ed) A Will to Survive: Indigenous Essays on the Politics of Culture, Language and Identity (McGraw Hill, New York, 2004) at 96. See also Upston-Hooper, above n 95, at 704-715.

123 Angela Ballara "The Innocence of History? The case of the 'Morioris' of Te Wai Pounamu a.k.a. the 'Waitaha Nation"” in Andrew Sharp and PG McHugh (eds) Histories, Power and Loss: Uses of the Past - A New Zealand Commentary (Bridget Williams Books, Wellington, 2001) at 123.

$124 \quad$ See Chapter 4.
} 


\section{B Raw Data}

The primary raw data used in the research are Māori Purposes Acts, as enacted, together with Māori Purposes Bills and explanatory notes. Amendments to Māori Purposes Acts are taken account of in subsequent Māori Purposes Acts.

I have reviewed New Zealand Parliamentary Debates, Journals of the House of Representatives, and various reports contained in Appendices to the Journals of the House of Representatives including reports of the Chief Judge of the Māori Land Court, reports of Royal Commissions, and annual reports of the Department and Committee. I have researched National Archives files relevant to particular case studies, together with available Cabinet records. Where relevant, decisions of the Māori Land Court and other Courts have been considered, and similarly, Waitangi Tribunal reports, historical reports and Treaty of Waitangi settlement documentation have been considered.

Given my intention to demonstrate the scope of the legislation, and because of the historic nature of many provisions and large volume of data, I have not attempted to consult widely with Māori about the legislation. I am conscious Māori have an oral history and reliance on government records could lead to an unbalanced perspective. ${ }^{125}$ To mitigate this risk I have looked for Māori voices in formal records. Debates in the House on Māori Purposes Bills were usually dominated by Māori Members of Parliament and provide a transcript of those Members' viewpoints. Petitions to Parliament were required to be submitted in written form, and contain grievances presented by Māori in their own words. ${ }^{126}$ Petitions have been recognised as "a fruitful source for understanding Maori perspectives of Crown-Maori relationships". ${ }^{127}$ There is also correspondence directly from Māori or from their representatives in National Archives files, including submissions to the Department and Committee, which I have considered in relation to particular case studies.

\section{Mixed-Methods Approach}

I have adopted a "mixed methods" approach, which involves quantitative and qualitative analysis, and the use of case studies. ${ }^{128}$

\footnotetext{
$125 \quad$ Above n 123, at 145.

126 Some petitions were written in Māori and have been translated.

127 David V Williams Te Kooti Tango Whenua: The Native Land Court 1864-1909 (Huia Publishers, Wellington, 1999) at 47 .

128 For an example of a mixed-methods approach see Malone, above n 37, ch 2. See also John W Creswell Research Design: Qualitative, Quantitative, and Mixed Methods Approaches (4 ${ }^{\text {th }}$ ed, Sage Publications, California, 2014).
} 
Analysis of provisions of Māori Purposes Acts revealed that due to the diverse nature of the provisions of the legislation, it was not possible to use quantitative analysis to demonstrate the nature and subjectmatter of the legislative provisions. ${ }^{129}$ While quantitative analysis contributes to the research, a qualitative approach was ultimately adopted. ${ }^{130}$ Quantitative analysis does usefully demonstrate particular trends observable in Māori Purposes Acts, such as the number and size of the Acts, the number of petitions being marshalled through the legislation, and aspects of legislative process.

I have assessed the content of Māori Purposes Acts using Llewellyn's law-jobs theory as the framework for identifying and explaining dominant purposes, processes and themes of the legislation. The concept and use of the term "washing-up" is central to my hypothesis. The meaning of "washing-up" in the context of Māori Purposes Acts has been extracted from the legislative process as recorded in Parliamentary debates, which is often confirmed in official records. ${ }^{131}$ The deconstructed concept is then used as a guide against which provisions of Māori Purposes Acts are measured for the purpose of ascertaining if the legislation was fairly represented or judged as containing inconsequential, technical provisions and processes. Where the phrase "washing-up" was not used or a distinction was drawn between that content and other provisions, this is acknowledged and considered.

Many provisions in Māori Purposes Acts are the outcome of long and complex historical disputes, which in many instances would be deserving of specific research and cannot be fully explored within this research project. ${ }^{132}$ Case studies have been used to obtain more specific insights and illustrate aspects of, and contrasts within, the purposes and processes of the legislation. It is important to acknowledge the fact-specific nature of many of these examples, and I have endeavoured to be careful in drawing broad conclusions from limited case studies. Provisions addressing claims and grievances were infrequently the end of the story, with grievances persisting into the modern Treaty of Waitangi settlements process, which has necessitated locating those provisions between the past and the present.

Quantitative analysis is numerical analysis that requires mutually exclusive "values" be attributed to every variable, which could not sensibly be achieved given the variability of provisions in the Māori Purposes Acts: see Lee Epstein and Andrew D Martin An Introduction to Empirical Legal Research (Oxford University Press, Oxford, 2014) at ch 5.

130 The term "qualitative" is used to describe a method of data analysis that is not numerical but is descriptive: see Epstein and Martin, above n, at 3-4. See also Wing Hong Chui "Quantitative Legal Research" in Mike McConville and Wing Hong Chui (eds) Research Methods for Law (Edinburgh University Press, Edinburgh, 2007) 46 at 48 for a comparison between the purposes of qualitative and quantitative methods.

131 See Chapter 4.

$132 \quad$ For example, see below n 534. 


\section{Conclusions and Perspectives}

Concerns have been raised about measuring the past by modern requirements, ${ }^{133}$ and the difficulties of drawing conclusions about the ideologies and motivations of people living in a different time. ${ }^{134}$ There have been many changes in New Zealand society and the political landscape during the timeframe of my research, which have impacted on the enactment and content of Māori Purposes Acts. I have endeavored to be mindful of these differences and to take account of the context in which provisions were enacted when drawing conclusions.

There may be a perceived tension between my approach in challenging characterisation of legislative provisions as merely "washing-up" from today's perspective, while accepting it may not be appropriate to measure legislative responses in terms of Treaty of Waitangi obligations. A distinction can be drawn between challenging how the legislation was represented at the time of enactment in the context of the significance and effect of many provisions and contrasting contemporaneous perspectives, compared with attempting to re-cast legislative responses in terms of Treaty of Waitangi obligations without contemporaneous evidence.

A final matter to be addressed is the role of the researcher, who determines the inquiry and conclusions drawn. As such, it is important that I identify my background, experience and connection with this research. ${ }^{135} \mathrm{I}$ am a Pākehā woman. I have worked as a solicitor in private practice for many years, and my work has included providing governance and commercial advice to Māori entities. My interest in Māori Purposes Acts began with my role as counsel for Wi Pere Trust in development of the Māori Purposes Act 2017, which is the perspective from which I began this research.

133 McHugh, above n 51, at 16-23.

134 Mark Francis "Writings on Colonial New Zealand: Nationalism and Intentionality" in McHugh and Sharp, above n 123 , at $186-188$.

135 See Creswell, above n 128, at 187-189. 


\section{Chapter 4: Enacting Māori Purposes Acts}

\section{Purpose of Chapter}

The key purpose of this chapter is to ascertain the meaning of the phrase "washing-up" as used in the House of Representatives, which conveyed expectations of legislative process and content of Māori Purposes Bills. This chapter will also outline key features of the legislative process before the House such as timeframes for passage of the legislation, scrutiny of the Bills, consultation with Māori and engagement in debates in the House. These preliminary conclusions will be built upon in subsequent chapters using specific subjects and case studies to provide more detailed insights into the process and the impact of the process on the content of Māori Purposes Acts.

\section{Origins of Legislative Process}

The legislative process visible in the enactment of Māori Purposes Acts derived from the process of enacting Native Land Amendment and Native Land Claims Adjustment Acts.

The Committee played a central role in the preparation and review of Native Land Amendment and Native Land Claims Adjustment Bills. The Committee's role was linked to its responsibility for considering the large number of petitions by Māori to Parliament, which were the source of claims provisions in the Bills. ${ }^{136}$ The Committee's role was considered "regular and formal", ${ }^{137}$ and it was presented to the House of Representatives as the basis upon which the House could have confidence in the provisions of these Bills, which were not widely understood outside the Committee. ${ }^{138}$ The involvement of the Department and Judges of the Native Land Court in consideration of claims provisions was also cited as a reason for the House not to be concerned with the content of the Bills. ${ }^{139}$ The Committee's oversight distinguished Native Land Amendment and Native Land Claims Adjustment Bills from the "European 'washing-up' Bill”, which did not receive any select committee attention and was considered less satisfactory. ${ }^{140}$

\footnotetext{
136 For explanations of the process, see (2 February 1922) 193 NZPD 96 and (1 November 1924) 205 NZPD 1047. See also (24 October 1911) 156 NZPD 965-966. See Chapter 6.

$137 \quad$ (1 November 1924) 205 NZPD 1047.

138 See for example (7 December 1918) 183 NZPD 924; (1 November 1924) 205 NZPD 1047 and 1049, (28 September 1925) 208 NZPD 774, (3 September 1926) 211 NZPD 294 and (1 November 1919) 185 NZPD 1209.

$139 \quad$ (2 February 1922) 193 NZPD 95.

140 See (7 December 1918) 183 NZPD 896 and (1 November 1924) 205 NZPD 1047. See also (27 October 1917) 181 NZPD 587. For Reserves and other Lands Disposal Acts see above nn 23-25.
} 
During this early period there were regular complaints about inadequate explanations of provisions in Native Land Amendment and Native Land Claims Adjustment Bills, with the Opposition wanting an explanatory memorandum to accompany each Bill or a detailed explanation in the House. ${ }^{141}$ There were also complaints about late introduction of these Bills near the end of the Parliamentary session, meaning there was little time to consider the contents properly. ${ }^{142}$ On the other hand, it was argued the very nature of a washing-up bill necessitated waiting for the Committee to finish considering the petitions that year before the bill could be introduced to the House. ${ }^{143}$ Dissatisfaction with late introduction of a "washingup" bill was not confined to the Native Land Amendment and Native Land Claims Adjustment Bills. ${ }^{144}$

\section{Process from 1931}

\section{A Focus}

Māori Purposes Bills were not specifically regulated by Standing Orders of the House of Representatives until 1996. ${ }^{145}$ Despite the absence of formal rules, the use and meaning of the phrase "washing-up" conveyed expectations as to the content of the Bills and the legislative process, which were affirmed in part by later Standing Orders. ${ }^{146}$ In considering the process of enacting Māori Purposes Acts I do not attempt to address changes in the composition of Parliament, ${ }^{147}$ or general changes to legislative process effected by Standing Orders. I focus on the predominant features relevant to Māori Purposes Acts. ${ }^{148}$

\section{B Meaning of "Washing-Up"}

The phrase "washing-up" was consistently used in the House of Representatives to describe Māori Purposes Bills, and it was also used to describe Local Legislation Bills, Reserves and other Lands

\footnotetext{
141 See for example (11 December 1913) 167 NZPD 1014 and (1 November 1919) 185 NZPD 1209-1210.

142 (1 November 1924) 205 NZPD 1048. Members' lack of understanding of the Bills was re-framed as a lack of interest by another Member: (1 November 1924) 205 NZPD 1048. See also (3 September 1926) 211 NZPD $293-294$.

$143 \quad$ For example (3 August 1916) 177 NZPD 736 and (6 October 1928) 219 NZPD 958.

144 (9 December 1918) 183 NZPD 1012 re the Reserves and other Lands Disposal and Public Bodies Empowering Bill 1918.

145 The only "washing-up" bills subject to specific rules in Standing Orders prior to 1996 were Local Legislation Bills: see Standing Orders of the House of Representatives (New Zealand) Relating to Public Business 1929, SO 372-381. See above n 46.

146 See Standing Orders of the House of Representatives 2017, SO 262(1)(d).

147 For example, abolition of the Legislative Council in 1950 and the introduction of MMP: see Martin, above n 5, and Malone, above n 37.

148 For legislative process generally, see Harris and Wilson, above n 24.
} 
Disposal Bills, Statutes Amendment Bills and Finance Bills. ${ }^{149}$ These "washing-up" bills were all later categorised as omnibus bills. ${ }^{150}$

In the case of Māori Purposes Bills use of the term "washing-up" had its origins in claims provisions, ${ }^{151}$ though it continued to be used to describe the Bills as the number of claims provisions declined and amendment provisions dominated the legislation. ${ }^{152}$ Analysis of New Zealand Parliamentary Debates reveals the phrase "washing-up" had a core meaning that indicated aspects of legislative process and expectations as to the content of Māori Purposes Bills, which are outlined in this chapter. In years when the phrase "washing-up" was not used, reference to its component meanings was often made instead.

\section{$1 \quad$ End of session measure}

The phrase "washing-up" indicated the bill was an end of session measure. Prior to changes in process in the mid-1980s, almost all Māori Purposes Bills were brought before Parliament at the end of the session, usually between September and December. ${ }^{153}$

As indicated above, this was because claims provisions were often contingent on resolution of petitions by the Committee, and because Māori Purposes Bills dealt with legal or practical difficulties that had accumulated during the year, prompting legislative amendments. ${ }^{154}$ The annual Māori Purposes Bill provided a convenient opportunity to deal with such matters. ${ }^{155}$ The observation of Sir Āpirana Ngata that Native Land Amendment and Native Land Claims Adjustment Bills met the "needs of the moment" remained an apt characterization of Māori Purposes Bills. ${ }^{156}$

Māori Purposes Acts contained many provisions dealing with Māori claims and disputes between 1930 and the early 1950s. Although some claims provisions, such as settlements, were contained in Māori Purposes Bills as introduced to the House by the government, claims provisions were often inserted by

\footnotetext{
149 Dollimore, above $\mathrm{n} 32$.

$150 \quad$ See above $\mathrm{n} 46$.

$151 \quad$ (5 October 1915) 174 NZPD 609.

152 This observation is based on examination of New Zealand Parliamentary Debates between 1931 and 2017. For example see (21 December 1933) 237 NZPD 1260 and 1311, (4 November 1983) 454 NZPD 3640 and (28 November 1989) 503 NZPD 13773.

153 This observation is based on analysis of New Zealand Parliamentary Debates 1931-1984. There were a few exceptions to this practice when bills were dealt at other times in the year, as occurred in 1937/38, 1943 and 1973.

$154 \quad$ (1 November 1924) 205 NZPD 1047.

$155 \quad$ (13 December 1988) 495 NZPD 8946.

$156 \quad$ (5 October 1915) 174 NZPD 617.
} 
the Committee during the legislative process. ${ }^{157}$ Occasionally, claims provisions were introduced by supplementary order paper. ${ }^{158}$

Amendment provisions were usually contained in Māori Purposes Bills as introduced to the House, but additional provisions were occasionally added while the bill was before the Committee or during Committee of the Whole stage. ${ }^{159}$ The source of amendment provisions depended on the nature of the amendment. Provisions implementing technical changes or improvements to existing policy and other legislation were often prompted by issues identified by Department staff during the year, by the Māori Land Court or New Zealand Māori Council. In many cases, the need for amendment was prompted by a particular situation or difficulty, such as decisions of the Courts the government did not like. ${ }^{160}$

In the case of provisions dealing with more private matters, provisions were either the result of petitions or direct advocacy by Māori to the Department or Minister, and were also included in Māori Purposes Bills as they arose to be dealt with at the end of the Parliamentary year. ${ }^{161}$

\section{$2 \quad$ Content}

It was expected that provisions in Māori Purposes Bills would be confined to Māori matters. ${ }^{162}$ It was also expected that provisions would be of a minor or non-controversial nature, an expectation that was clearly articulated in debates during the passage of the Māori Purposes Act $1991 .^{163}$ Descriptions of provisions as "miscellaneous" or "sundry" in the House also conveyed the expectation provisions were minor. ${ }^{164}$ It was common for observations to be made that Māori Purposes Bills were of a "tidying-up"

\footnotetext{
157 A particularly good example was in 1938. The Native Purposes Bill 1938 (45-1) as presented to the House contained only 15 clauses compared with the Native Purposes Act 1938 which contained 23 clauses. The difference was due to claims provisions inserted by the Committee, predominantly as the result of recommendations as to petitions: see Native Purposes Bill 1938 (45-2) (select committee report). See Arahura River bed, below n and nn 602-605.

See $(8$ December 1976) 408 NZPD 4645-4651.

See below nn 311-318 and nn 372-378. For sources of legislation see Carter, above n 19, at 41-59.

See Chapter 8.

Dollimore, above n 32, at 26 which recognised "washing-up" bills "related to a particular field of legislation". See also McGee, above n 33, at 426.

(13 December 1988) 495 NZPD 8943-8952, (28 November 1989) 503 NZPD 13773-13778 and (3 April 1990) 506 NZPD 1286. See also (10 September 1981) 441 NZPD 3318.

(8 October 1941) 260 NZPD 1060, (24 November 1944) 267 NZPD 340, (5 December 1945) 272 NZPD 372 and (15 October 1970) 369 NZPD 4075.
} 
nature, ${ }^{165}$ and contained "machinery" provisions, ${ }^{166}$ which conveyed the technical and administrative nature of the clauses in comparison with policy. Dismissive references were repeatedly made to the "usual" or "ordinary" washing-up bill, which served to reinforce these assumptions and represented there was nothing concerning or significant in the bills. ${ }^{167}$ It was clear that Māori Purposes Bills were not expected to contain significant or important policy. In theory the Bills were intended to deal with Māori claims and technical matters, with significant policy to be addressed in principal legislation, an expectation that was expressly stated in later years. ${ }^{168}$

Regardless of expectations, there were years when the government accepted the Māori Purposes Bill was of a different nature to the usual "washing-up" bill, containing important policy or resolving longstanding grievances. In such cases the phrase "washing-up" was either not employed to describe the contents of the bill, ${ }^{169}$ or a demarcation was made between the "washing-up" content of a bill and provisions considered to be consequential, a trend more noticeable from the 1950s. ${ }^{170}$

It may have suited governments of the day to adopt the "washing-up" characterisation in order to slip a range of provisions through the legislative process without incurring much scrutiny outside the Committee. In 2006 the Leader of the Māori Party suggested that representing the "peculiar nature of omnibus bills" as "wash-up legislation" was a tactic, and one his party was cautious about based on past experience of the content of such bills. ${ }^{171}$ If representation of Māori Purposes Bills as "washing-up" measures was a deliberate strategy to avoid attention and pass legislation quickly, it did not always succeed. Objections were provoked when the Opposition party did not consider the characterisation fair in the context of the bill before the House. ${ }^{172}$

165 (28 November 1961) 329 NZPD 3817, (15 October 1976) 407 NZPD 3143, (13 December 1988) 495 NZPD 8946, (4 April 2001) 591 NZPD 8748 and (1 April 2003) 607 NZPD 4803. The tidying-up nature of Māori Purposes Bills is acknowledged by Harris and Wilson, above n 24, at 375 .

166 See for example (5 December 1945) 272 NZPD 445, (26 November 1953) 301 NZPD 2504, (11 December 1968) 359 NZPD 3814, (19 October 1979) 426 NZPD 3674, (4 November 1983) 454 NZPD 3641 and (13 December 1988) 495 NZPD 8943. See for example (11 March 1938) 250 NZPD 297, (6 October 1972) 381 NZPD 3114 and (17 October 1974) 395 NZPD 5115.

168 (19 October 1979) 426 NZPD 3673; (13 July 1999) 579 NZPD at 17965. See Native Purposes Act 1931 and (28 October 1931) 230 NZPD 559. See also the Maori Purposes Act 1973, which dealt with the Ngāi Tahu settlement: (6 March 1973) 382 NZPD 499-504; (8 June 1973) 383 NZPD 1197-1203. See chapter 7 . For example, see (29 November 1950) 293 NZPD 4722; (6 October 1955) 307 NZPD 2839; (11 December 1968) 359 NZPD 3814; and (13 September 1973) 385 NZPD 3575.

$171 \quad$ (27 June 2006) 632 NZPD 3963.

172 See below nn 216-218. 
From the mid-1980s, the term "washing-up" was less commonly used to describe Māori Purposes Bills, and in more recent years the phrase has ceased to be employed, with the phrase entirely absent from Parliamentary debates during the passage of the Māori Purposes Acts 2011 and 2017. ${ }^{173}$ This change likely reflects shifting attitudes about the importance of legislation affecting Māori, altered expectations as to legislative process and a change in terminology, with "washing-up" bills now known as omnibus bills.

\section{Passage through House of Representatives}

As indicated in the literature review, the various stages of a bill's passage through the House of Representatives are designed to ensure legislation is necessary and fit for purpose, ${ }^{174}$ allowing for explanation of a bill, policy debate, public consultation and detailed consideration of provisions. ${ }^{175}$ It is useful to examine whether these stages were observed in the passage of Māori Purposes Bills, which will enable conclusions to be drawn about the scrutiny the Bills were subjected to and provide an indication of attitudes toward the Bills.

\section{$1 \quad$ Pattern prior to mid-1980s}

Māori Purposes Bills frequently passed through the House in very short timeframes in comparison with today's standards as indicated in Figure 2 below. In the 1930s and 1940s it was not unusual for Māori Purposes Bills to take less than a week to pass through all stages in the House, including Legislative Council. ${ }^{176}$ From the late 1960s the timeframe for passage of Māori Purposes Bills through the House began to lengthen, a trend that continued through the 1970s and into the mid-1980s, coinciding with a general trend towards smaller Māori Purposes Acts. ${ }^{177}$

It was not only bills with minor, machinery or administrative provisions that passed through the House quickly. Māori Purposes Bills containing important policy provisions and claims provisions were also

\footnotetext{
173 See chapter 8.

$174 \quad$ Above $\mathrm{n} 33$.

175 For principles of good process, see Geiringer, Higbee and McLeay, above n 44, and see Harris and Wilson, above n $24, \operatorname{ch} 26$.

176 The Native Purposes Act 1934 passed through all legislative stages before the House in two days: (9 November 1934) 240 NZPD 1259, 1289 and 1278. In the 1940s half the Māori Purposes Acts passed through the House in less than a week; the remainder took up to two weeks.

177 See Figure 1. After 1960, only one Māori Purposes Act passed through the House in a week, in 1978: (29 September and 5 October 1978) 421 NZPD 4008-9, 4267 and 4273.
} 
prone to quick passage, which is seen in 1938, 1947, 1949, 1950, 1951 and 1953. ${ }^{178}$ No concerns about the short timeframe for examining the legislation were raised in any of these years.

The process of urgency was persistently invoked in one or more stages of the passage of the legislation, as depicted in Figure 2. Urgency no doubt ensured Māori Purposes Bills were passed before the end of the session, but the quick passage cannot be solely attributed to the use of urgency. In earlier decades, Standing Orders enabled bills to pass swiftly through the House, without stand-down periods between legislative stages and no prescribed period for Select Committee consideration compared with current Standing Orders. ${ }^{179}$ And despite the persistent use of urgency timeframes for passage of Māori Purposes Acts increased over time.

2

Changes in process from 1984

The predictable legislative process of enacting Māori Purposes Acts changed from 1984, which affected the content and frequency of the legislation. Māori Purposes Bills were no longer introduced every year or at the end of the Parliamentary session. From the mid-1980s Māori Purposes Acts usually took months or years to pass through all legislative stages in the House. ${ }^{180}$

From 1984 Māori Purposes Bills were frequently divided at Committee of the Whole stage, with specific amendment Acts used to enact policy changes and amendments previously contained in Māori Purposes Acts. ${ }^{181}$ The process of dividing bills sometimes resulted in small Māori Purposes Acts, and at other times no Māori Purposes Act was enacted because all clauses in the Māori Purposes Bill were enacted in specific amending Acts. ${ }^{182}$ In other years specific amending bills were used instead of a Māori

The Maori Purposes Acts of 1949 and 1951 are perhaps the worst examples given their significant policy content, passing through the legislative process within only days with minimal or no recorded debate: see (4 and 5 December 1951) 296 NZPD 1330 and 1358-1359 and (18, 20 and 21 October 1949) 288 NZPD 2893, 3007 and 3045. See Chapter 5. The Native Purposes Act 1938, which contained a multitude of claims provisions, passed through the House in eight days.

179 Compare Standing Orders of the House of Representatives (New Zealand) Relating to Public Business 1929, SO 310-355 with Standing Orders of the House of Representatives 2017, SO 276-317. The Maori Purposes Act 1991 took over two and a half years to progress through the House: (13 December 1988) 495 NZPD 8943 and (13 June 1991) 515 NZPD 2371.

181 For example, the Maori Purposes Bill 1988 (121-1) was divided into separate bills, with only the clauses dealing with the governance arrangements for Wi Pere Trust enacted as the Maori Purposes Act 1991.

182 For example, the provisions of the Maori Purposes Bill 1995 (78-1) were enacted as the Maori Affairs Restructuring Act 1996, Maori Community Development Amendment Act 1996, Maori Trustee Amendment Act 1996, Te Ture Whenua Maori Amendment Act 1996 and the Maori Trust Boards Amendment Act 1996. 
Purposes Bill. ${ }^{183}$ Prior to this change in procedure the annual Māori Purposes Act had closely resembled the Māori Purposes Bill before the House. There were also two anomalies in the usual legislative process where Māori Purposes Acts did not derive from a government Māori Purposes Bill. ${ }^{184}$

The legislative pattern of enacting Māori Purposes Acts is depicted in Figure 2 below.

183 In 1998 no Māori Purposes Bill was introduced to the House but see Te Ture Whenua Amendment Bill 1998 (3361) and Maori Reserved Land Amendment Bill (No 2) 1998 (103-1).

184 The Maori Land Amendment and Maori Land Claims Adjustment Act 1996 derived from the Law Reform (Miscellaneous Provisions) Bill (No 5) 1996 (148-2), see explanatory note, at iv-v. The Maori Purposes Act 1994 was initially introduced as a private members bill: see Wi Pere Trust, Chapter 8. 
Figure 2: Legislative Process ${ }^{185}$

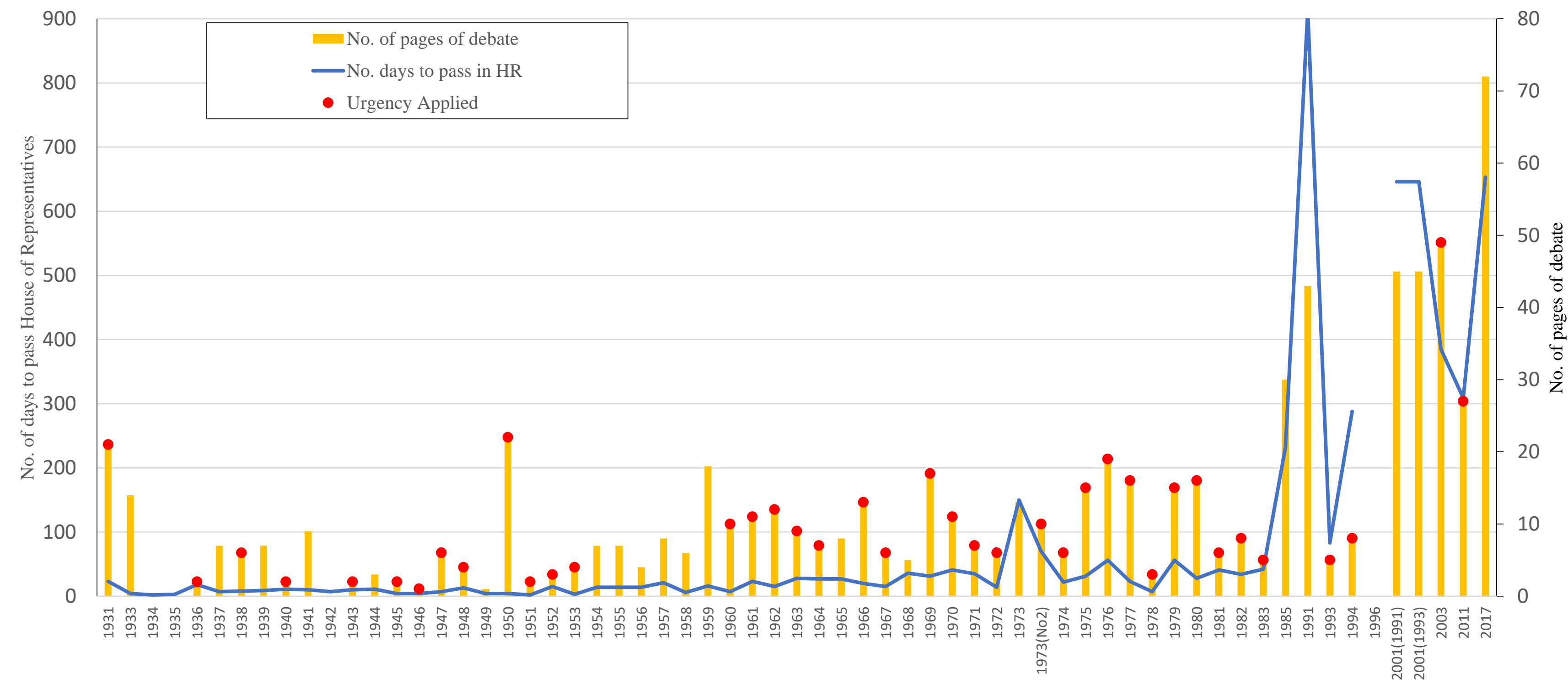

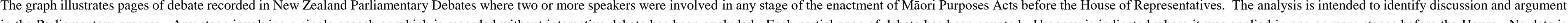

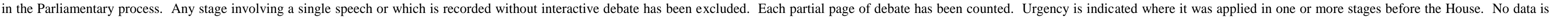
recorded in years that no Māori Purposes Act was enacted, and no data is entered for 1996 because the process was an anomaly, see above n 184. The number of days to pass through the House includes all relevant stages from introduction. 
Although the enactment process was usually settled, some years the Opposition party complained there was insufficient time to consider Māori Purposes Bills properly, reflecting earlier objections to hurried timeframes. ${ }^{186}$ In 1933 the Leader of the Opposition wanted more time to understand clauses that proposed to transfer the Native Minister's land development powers to the Minister of Finance and the Native Land Settlement Board, which was considered a drastic curtailment of the Native Minister's powers. ${ }^{187}$ In 1958 and 1959 complaints were made about the government pushing the Bills through at unreasonable hours and placing undue pressure on the Committee to report back quickly. ${ }^{188}$ Further complaints about short timeframes were made from the 1970s onwards, with notable examples in 1975, 1977 and 1980, where these objections were linked to dissatisfaction about consultation with Māori. ${ }^{189}$

\section{Debates}

From the 1930s to the early 1950s, Māori Purposes Acts were occasionally enacted without any recorded debate, and more often, with minimal debate. ${ }^{190}$ Since the late 1950 s this has rarely been the case, and the passage of most Māori Purposes Bills has involved at least one or more substantive debates following consideration of the Bill by the Committee. From the 1970s recorded debates were generally longer, reflecting more sustained attention to the content of the Bills, and in more recent years all stages before the House have been observed. ${ }^{191}$ Passage of the most recent Māori Purposes Acts involved full legislative process as depicted in Figure 2.

Debates were not always focused on the content of Māori Purposes Bills, and were sometimes used as a platform by Māori Members to raise other important issues affecting Māori, detracting attention from the content of the Bills. ${ }^{192}$ Participation in debates about Māori Purposes Bills was often limited to contributions from Māori Members of Parliament, Members of the Committee and the Minister, although issues relating to monetary settlements or special arrangements have stimulated wider discussion among

\footnotetext{
$186 \quad$ Above nn 141-143.

187 (20 December 1933) 237 NZPD 1260-1262 and 1269-70. For an historic account see Richard S Hill State Authority, Indigenous Autonomy: Crown-Maori Relations in New Zealand/Aoteoroa 1900-1950 (Victoria University Press, Wellington, 2004), at 118-127.

188 (19 September 1958) 318 NZPD 1925-1926 and (15 October 1959) 321 NZPD 2457-2458.

189 See (20 November 1980) 435 NZPD 5143, and see below nn 206-218.

190 See Figure 2.

191 The Māori Purposes Acts of 1991, 2011 and 2017 provide examples.

192 (11 March 1938) 250 NZPD 299-301, (22 September 1939) 256 NZPD 287, (26 November 1947) 279 NZPD 109193 and (6 December 1979) 427 NZPD 4568-4571.
} 
Members of the House. ${ }^{193}$ In 1959 the Member for Southern Māori expressly commented on poor attendance in the House when Māori Purposes Bills were being dealt with. ${ }^{194}$

Absence of substantive debate at every stage of the legislative process curtailed opportunities to fully examine and improve provisions in the Bills. Examination of debates that did occur reveals limited understanding of provisions, which was not assisted by sparse summaries in explanatory notes in earlier decades and little explanation in the House, which was problematic in the context of complex historic grievances and changes in policy direction. Although not common, there are examples of debate identifying issues missed by the Committee, resulting in changes being made at Committee of the Whole Stage. ${ }^{195}$

An example of the perils of the "washing-up" mischaracterisation, lack of debate and inadequate explanatory notes is illustrated by a provision in the Native Purposes Act 1935 dealing with renewals of leases, in respect of which the "inadequate" legislative process was criticised by a Royal Commission. ${ }^{196}$

\section{$5 \quad$ The Committee}

The practice of referring Native Land Amendment and Native Land Claims Adjustment Bills to the Committee set a precedent that continued with Māori Purposes Bills, and preceded widespread referral of bills to select committees from 1979. ${ }^{197}$ Members holding Māori electoral seats invariably sat on the Committee, although the Minister of Māori Affairs did not always do so. ${ }^{198}$

Despite some criticisms of New Zealand's select committee system, the select committee stage is generally viewed as the most important component of New Zealand's legislative process. ${ }^{199}$ In years where there was minimal substantive debate about Māori Purposes Bills, examination by Committee was

\footnotetext{
193 See below nn 216-218, 485-486 and 665-673.

$194 \quad$ (14 October 1959) 321 NZPD 2449.

195 In 1938 Sir Āpirana Ngata protested the definition of "person under disability" and secured a change of wording: (15 September 1938) 253 NZPD 485-486. For an inconsistency the Committee had not identified see: (30 October 1964) 341 NZPD 3073-3074 and (5 November 1964) 340 NZPD 3213-3214.

196 Native Purposes Act 1935, s 19. See Royal Commission "Report of Royal Commission to Inquire into and Report on Claims Preferred by Members of the Maori Race Touching Certain Lands Known as Surplus Lands of the Crown" [1948] III AJHR G8 at 23.

197 See Martin, above n 5, at 260 and 286. It has been suggested that prior to 1979 approximately 30\% of government bills were referred to select committee: Harris and Wilson, above n 24, at 407.

198 This observation is based on review of the composition of the Committee recorded in Appendices to the Journals of the House of Representatives during the period of the research.

199 Above nn 37-42.
} 
the only scrutiny the Bills received before being passed into law. The Committee has been described as a "miniature Parliament" dealing exclusively with Māori affairs, and as a committee in which the House has "a great deal of trust". ${ }^{200}$ Some Members of Parliament have recognised the specialist knowledge required for consideration of the Bills. ${ }^{201}$ The Committee has been depicted as being able to put aside political differences and work together, ${ }^{202}$ and there have been few observable divisions within the Committee, with notable exceptions in 1961 and $1984 .^{203}$

Most amendments to Māori Purposes Bills have been effected by the Committee, and its recommendations to the House have invariably been read into the Bills. ${ }^{204}$ Sometimes the Committee was able to intervene in government policy, securing the removal of clauses which the Committee considered controversial, such as removal of a right of appeal from orders of court registrars, or clauses in need of further consultation or consideration. ${ }^{205}$ The fact most amendments to Māori Purposes Bills were the result of the Committee's scrutiny and recommendations is consistent with general observations of legislative process in New Zealand.

The settled passage of most Māori Purposes Bills through the House and the invariable acceptance of the Committee's recommendations lends weight to perceptions the Committee has been able to work together co-operatively and held the trust of the House.

Modern legislative process recognises the importance of consultation with Māori in the development of policy. ${ }^{206}$ However, consultation with Māori in the preparation of Māori Purposes Bills was inconsistent and expectations about consultation have developed over time.

From the 1970s there was clear dissatisfaction in the House about inadequate consultation with Māori about the legislation, which likely reflected changing perceptions of acceptable legislative practice and

$200 \quad$ (20 December 1933) 237 NZPD 1268.

$201 \quad$ (28 October 1931) 230 NZPD 569 and (20 December 1933) 237 NZPD 1267-68.

202 (4 May 2017) 721 NZPD 17713-17731. See also (13 September 2011) 675 NZPD 21263.

203 See below nn 216-218 and 303-308.

204 This observation is based on examination of Māori Purposes Acts as enacted compared with Māori Purposes Bills reported back to the House by the Committee, together with New Zealand Parliamentary Debates. 4085.

206 Cabinet Office Cabinet Manual 2017 at [7.44]. 
growing awareness of the importance of issues affecting Māori. ${ }^{207}$ The New Zealand Māori Council was consulted about the Bills from the 1960s, ${ }^{208}$ but in 1982 the Minister of Māori Affairs acknowledged his Department had recently become "much more concerned" with consulting Māori. ${ }^{209}$ In the absence of consistent, quality consultation with Māori in the development of the legislation, the Committee's role in receiving public submissions was crucial if the legislative provisions contained in Māori Purposes Acts were to be effective and durable.

Although objections to the process of enactment were not frequent, concerns about the quality of consultation with Māori were frequently the source of any discontent. In 1975 the opposition party questioned the quality of consultation with Māori in respect of provisions implementing recommendations of a Royal Commission of Inquiry because inadequate time had been allowed for consideration of the Commission's lengthy report and public submissions. ${ }^{210}$ However, the Minister was satisfied that consultation with advisory groups provided a sufficient basis for proceeding. ${ }^{211}$ There was also robust debate over whether proposed changes to the status of land held by Māori incorporations reflected what Māori had asked for. ${ }^{212}$ In 1977 opposition Members again challenged the quality of consultation with Māori incorporations in the preparation of the bill, and objected to the short timeframe proposed for the Committee to hear submissions, compromising proper consultation. ${ }^{213}$

Clauses have been removed from Māori Purposes Bills on the recommendation of the Committee because of concerns that further consultation or evaluation was required, which was usually achieved without controversy in the House. In 1974 the Minister accepted that clauses that would have made "major changes" to the functions of district Māori Councils and the New Zealand Māori Council, and which were not supported by the New Zealand Māori Council, should be removed from the Bill to enable better consultation. ${ }^{214}$ Other examples can be seen in 1958,1980 and $1983 .{ }^{215}$

For political changes in New Zealand politics see Martin, above n 5, ch 8 and Alan McRobie "The Politics of Volatility" in Geoffrey W Rice (ed) The Oxford History of New Zealand ( $2^{\text {nd }}$ ed, Oxford University Press, Auckland, 1992) 385. For Māori protest, see Hill, above n 51, ch 7.

(28 November 1961) 329 NZPD 3811.

(29 October 1982) 448 NZPD 4313.

Maori Purposes Act 1975, Pt III. See (7 October 1975) 402 NZPD 5256-5259.

Above $\mathrm{n}$ at 5258-5259.

See nn 322-339.

(24 November 1977) 416 NZPD 4741-4750.

(17 October 1974) 395 NZPD 5115 and 5622.

See Maori Purposes Bill 1958 (84-2) (select committee report), cl 9, and (23 September 1958) 318 NZPD 19831984; Maori Purposes Bill 1980 (120-2) (select committee report), cl 4 and 8, and (20 November 1980) 435 NZPD 5142; and Maori Purposes Bill 1983 (97-2) (select committee report), cl 4 and 7, and (13 and 15 December 1983) 455 NZPD 4829 and 5011. 
In comparison, in 1984 provisions that provided for abolition of the conversion fund established for the purpose of enabling the Māori Trustee to acquire "uneconomic interests" in Māori land, and which provided for transfer of money in the fund to another account under the control of the Minister of Finance, provoked unusually strong opposition in the House. ${ }^{216}$ The Committee sought an instruction from the House to split the Bill in order to separate the controversial provisions from the provisions that could proceed without difficulty, which was an unprecedented procedural step. For the first time a Māori Purposes Bill was split into separate amending bills, ${ }^{217}$ and the government indicated it would give the Conversion Fund clause further consideration. ${ }^{218}$ The provision abolishing the conversion fund was later enacted in the Maori Affairs Amendment Act 1987 with the Māori Trustee retaining control of the funds.

\section{Conclusions}

Although Māori Purposes Bills were not formally regulated until 1996, there was an established procedure and clear expectations about the content of these "washing-up" bills. The phrase "washingup" conveyed that a Māori Purposes Bill was an end of session measure, containing machinery or technical provisions of a minor and non-controversial nature relating to Māori affairs. This characterisation was not intended to encompass significant new policy or controversial matters.

The process of enacting Māori Purposes Bills was usually straight forward and without controversy, despite the fact these government Bills were regularly pushed through the legislative stages before the House in very short timeframes, often under urgency. Until more recently, this hurried process applied even where Māori Purposes Bills contained provisions that were acknowledged to be important, or which implemented new policy. The process of enacting Māori Purposes Acts reflects general concerns about the speed of New Zealand's legislative process.

Although many Māori Purposes Bills were enacted without substantive debate, and with limited understanding in the House of the history of the matters that necessitated legislative provisions, a distinct feature and strength of the legislative process was the invariable referral of Māori Purposes Bills to the Committee for specialist examination. This feature of the process reflects the strongest element of New Zealand's legislative process, and in the case of Māori Purposes Bills, it was a practice that occurred in advance of widespread referral of bills for select committee scrutiny. Most changes to Māori Purposes Bills were recommended by the Committee, and on occasion the Committee was able to secure the removal of clauses it was unhappy with.

$216 \quad$ Maori Purposes Bill 1984 (55-1), cl 6.

217 (20 March 1985) 461 NZPD 3821-3824. Clause 6 was removed into the Maori Affairs Amendment Bill 1985 (552A): (30 May 1985) 462 NZPD 4358-4365. The remaining clauses in the Maori Purposes Bill 1984 were also divided into separate bills, with only a few clauses enacted as the Maori Purposes Act 1985.

218

(30 May 1985) 462 NZPD 4364. 
Limited engagement in the House may have reflected a general complacency about, or disinterest in, Māori affairs or the technical nature of many Māori Purposes Bills, particularly in earlier decades. Alternately, it may have reflected a high degree of confidence and trust in the knowledge and skill of the Committee to examine the Bills and make recommendations where necessary. It is also possible that other demands on House time, such as World War II, contributed to sparse examination of the Bills.

There was a tendency towards more substantive debates by the 1970s, with more detailed consideration of the content of the Bills. From the 1970s onwards, there was notable dissatisfaction with short legislative timeframes, and demand for consultation with Māori, issues which have largely been resolved by changes in legislative process, and modern expectations about consultation. The passage of the Māori Purposes Act 2017 marks a complete departure from earlier legislative process with full debate and without urgency.

Subsequent chapters will examine these issues and explanations further in the context of specific subjects and case studies, and will assess the content of the legislation against the expectations of a "washing-up" bill. 


\section{Chapter 5: Government Machinery, Policy and Amendments}

\section{Introduction}

One of the key purposes of Māori Purposes Acts was to amend the existing Māori legislative framework, changes that were collated throughout the year and placed in the annual bill. Provisions included machinery, technical or administrative provisions that facilitated operation of the legal system, and minor amendments that were straight-forward and uncontroversial. Other amendments were more significant, and at times the legislation was used to enact wholly new government policies, particularly in the late 1940s and early 1950s. Provisions that introduced policy changes were not consistent with the concept of "washing-up", although there was little objection within the House to use of the legislation in this manner.

This chapter reflects the difficulties and short-comings of restrictive legal regimes controlling Māori life, which has been the subject of criticism and resolution within the modern Treaty of Waitangi settlements process. There are also indications that Māori Purposes Acts were a convenient mechanism to trial or experiment with new policies and amendments, which if proved successful, were later encompassed in larger policy reforms to principal legislation. Policy and amendment provisions covered a wide range of subject matters from principal land legislation, to regimes controlling the office of the Māori Trustee and Māori trust boards, and legislation affecting the lives of Māori communities such as the Maori Social and Economic Advancement Act 1945 and legislation providing for Māori housing. ${ }^{219}$

I have focused on a range of subject matters to explore the scope of policy and amendment provisions prior to 1985, the point at which the frequency and scope of Māori Purposes Acts dramatically reduced. Machinery and administrative provisions are considered in the context of provisions relating to the Māori Land Court and Māori Trustee. Amendment provisions are explored primarily within the context of adoptions, marriage and Māori incorporations, subjects which were frequently addressed in the legislation and included elements of new policy. Significant new policy is explored with provisions introducing and then amending Māori trusts.

\section{Machinery and Minor Provisions}

The legislation did contain many provisions of an administrative, machinery, technical and minor nature, which served a variety of purposes, and did not necessarily require significant attention during the

219 See for example, Maori Purposes Act 1949 and Maori Purposes Acts 1959-1961. 
legislative process. Such provisions were true to the concept of "washing-up" as it had developed. These provisions usually passed through the legislative process without comment.

Machinery provisions included those providing for the administration of the Māori Land Court, such as setting the salaries of its Judges and enabling the appointment of temporary Judges, ${ }^{220}$ providing for the appointment of deputy registrars, ${ }^{221}$ amending names of owners on the Court's records, ${ }^{222}$ and providing for the extension of sittings of the Court and issue of practice notes. ${ }^{223}$ While such provisions could fairly be considered minor, other provisions relating to the administration of the Court were perhaps more significant. For example, provisions established a rules committee, ${ }^{224}$ extended registrars' powers and abolished Commissioners of the Māori Land Court, ${ }^{225}$ and implemented recommendations of the Royal Commission on the Māori Land Court in the context of dissatisfaction about the operation of the Court. $^{226}$

Provisions also dealt with the general jurisdiction of the Māori Land Court. ${ }^{227}$ Some of these provisions were not significant extensions of existing jurisdiction such as a provision clarifying the jurisdiction of the Court to determine the status of land as Native or European in the course of proceedings before the Court. $^{228}$ Other examples of relatively minor adjustments included extension of the Court's jurisdiction to include general land owned by Māori, ${ }^{229}$ and extension of its jurisdiction in claims for trespass or injury to Māori freehold land, giving the Court authority over Europeans as well as Māori up to the same monetary limit as the District Courts. ${ }^{230}$

However, it cannot be assumed all provisions dealing with the general jurisdiction of the Māori Land Court were innocuous or insignificant. An illustration is seen with a provision that widened the Court's power to issue collateral charges on land as security for monies advanced by the Maori Land Board for housing. Such charges were already permitted against the land interests of the borrower, but the

\footnotetext{
220 Maori Purposes Act 1960, s 4, Maori Purposes Act 1966, ss 2-3, Maori Purposes Act 1970, s 3 and Maori Purposes Act 1978, s 2.

$221 \quad$ Native Purposes Act 1945, s 4.

222 Maori Purposes Act 1974, s 3.

223 Maori Purposes Act 1976, ss 3 and 4.

$224 \quad$ Maori Purposes Act 1980, s 3.

225 Maori Purposes Act 1982, ss 3, 5 and 9.

226 Royal Commission "Report of the Royal Commission of Inquiry: Maori Land Court" [1980] IV AJHR H3 at 127132. See (20 November 1980) 435 NZPD 5141-5142.

227 Provisions conferring case-specific jurisdiction are dealt with in following chapters.

$228 \quad$ Native Purposes Act 1939, 3.

$229 \quad$ Maori Purposes Act 1981, s 3.

$230 \quad$ Maori Purposes Act 1982, s 6.
} 
provision gave the Court power to impose a charge on the land or land interests of "any other native who has derived or may derive any benefit from the expenditure of the moneys."231 The provision was intended to permit charges against land owned by a borrower "and his wife" but it was broadly drafted enabling wider application. ${ }^{232}$ A subsequent Māori Purposes Act curbed this provision, requiring the consent of the person owning the estate or interest over which a collateral charge was proposed to be taken. $^{233}$

The powers and responsibilities of the Māori Trustee were frequently adjusted by Māori Purposes Acts. Many provisions were fairly treated as being of a minor or machinery nature and did not prompt debate or objection, such as those altering the manner in which the Māori Trustee could issue cheques, ${ }^{234}$ increasing monetary amounts pertaining to administration of estates without a grant of administration, ${ }^{235}$ and extending the Māori Trustee's powers, such as permitting donations. ${ }^{236}$ Provisions dealing with the Māori Trustee's responsibility for, or contribution to funding, guest houses, hostel accommodation and community halls for Māori in the cities commonly appeared in Māori Purposes Acts. ${ }^{237}$

However, as with provisions affecting the Māori Land Court, there were more significant provisions in the legislation adjusting the role and powers of the Māori Trustee. An example was the introduction of a provision allowing the Māori Trustee to reject small claims using a process that was not subject to the oversight of the Supreme Court, which was described as a matter of machinery. ${ }^{238}$ This provision prompted opposition from the Member for Southern Māori who disliked the move toward giving the Māori Trustee "increased authority which can be implemented in a dictatorial manner". ${ }^{239}$

Provisions regularly dealing with the Māori Land Court and Māori Trustee provide just two examples of the type of provisions characterised as machinery or administrative provisions. Other examples include provisions enabling the issue of certificates of title to facilitate existing land development policy, ${ }^{240}$

\footnotetext{
$231 \quad$ Native Purposes Act 1942, s 5.

$232 \quad$ Native Purposes Bill 1942 (20-1) (explanatory note), cl 5.

$233 \quad$ Maori Purposes Act 1959, s 33.

$234 \quad$ Maori Purposes Act 1966, s 12.

235 Maori Purposes Act 1971, s 7 and Schedule, Maori Purposes Act 1978, s 3.

$236 \quad$ Maori Purposes Act 1947, s 20.

237 Native Purposes Act 1940, s 10, Native Purposes Act 1944, s 9, Maori Purposes Act 1949, ss 22 and 27 , Maori Purposes Act 1969, s 15, Maori Purposes Act 1970, s 12 and Maori Purposes Act 1974, s 9.

238 Maori Purposes Act 1971, s 6 and (15 December 1971) 377 NZPD 5344. Compare the Trustee Act 1956, s 75. A comparable small claims provision was also enacted in respect of the Public Trustee: Public Trust Office Amendment Act 1971, s 6 .

239 (15 December 1971) 377 NZPD 5345-5346.

$240 \quad$ Native Purposes Act 1939, ss 4 and 5 and (22 September 1939) 256 NZPD 287-288.
} 
provisions facilitating the establishment of memorials for Māori politicians, ${ }^{241}$ and minor provisions in respect of Māori incorporations. $^{242}$ Machinery and administrative provisions were not significant extensions of existing policy but they were often essential to the functioning of the legal system and made important and necessary adjustments. While it was reasonable to characterise such provisions as "washing-up" measures, it was not accurate to represent or assume all Māori Purposes legislation was of a "washing-up" nature, which is explored below.

\section{Questioning the "Washing-Up" Characterisation}

\section{A Native Purposes Act 1943}

The Native Purposes Act 1943 provides a particularly good example of the fallacy of the "washing-up" characterisation. The Act did not contain only machinery or minor provisions. Among provisions that were genuinely straight-forward and uncontroversial, were entirely new policy provisions and significant amendments with important or detrimental consequences, which were not well scrutinised.

The 1943 legislation was described as being of "a specific character" about which little needed to be said because it had been before the Committee and met with their "unanimous wishes". ${ }^{243}$ This characterisation no doubt reflected subjective interpretations of the Bill and colonial values of government during this time.

The Act introduced a provision authorising the return of land taken for public works to Māori if the land was no longer required for that public work or any other public purpose. ${ }^{244}$ This provision was enacted to avoid the need for special legislation each time land was to be returned, and was subsequently incorporated in the Maori Affairs Act 1953. ${ }^{245}$ Further amendment in 1975 expanded the policy to permit the return of land to Māori if not required for the specific public work or purpose for which it had been taken. ${ }^{246}$ Another positive provision in the 1943 Act strengthened the prohibition on unauthorised cutting of timber on Māori land, prompted by a failed prosecution against a Pākehā who escaped penalty because the timber had not been removed from the land. ${ }^{247}$

\footnotetext{
$241 \quad$ See Native Purposes Act 1936, s 11, Native Purposes Act 1937, ss 11 and 15 and Maori Purposes Act 1952 , s 11. See also Native Purposes Act 1934, s 8.

242 Below nn 322-325.

$243 \quad$ (25 August 1943) 263 NZPD 1067.

$244 \quad$ Native Purposes Act 1943, s 7 and Native Purposes Bill 1943 (29-1) (explanatory note), cl 7.

$245 \quad$ Maori Affairs Act 1953, s 436.

246 Maori Purposes Act 1975, s 6.

$247 \quad$ Native Purposes Act 1943, s 6. See also Native Purposes Bill 1943 (29-1) (explanatory note), cl 6.
} 
In contrast to those relatively positive amendments was a provision addressing succession problems arising from people on Māori land titles who were not "native". ${ }^{248}$ The legislation empowered the Native Land Court to make succession orders in respect of interests in Māori land held by Europeans in accordance with the general law, not Māori custom. ${ }^{249}$ This enabled alienation of the land by Europeans, while Māori continued to be restricted from passing interests in Māori land to Europeans. ${ }^{250}$

The 1943 Act also created an exception to the prohibition on the Crown buying Māori land at less than government valuation, allowing the government to accept land as a gift or to purchase it at less than government valuation where the land was being acquired to settle Māori and descendants of Māori, in particular discharged servicemen. ${ }^{251}$ Although enacted in the context of other wartime measures taking land for settlement, from which Māori land was protected, this provision undermined the long-standing protection afforded to Māori in dealings with the Crown since 1909 and deserved to be carefully debated. $^{252}$

Most significantly, the Native Purposes Act 1943 introduced a novel provision permitting the establishment of Māori trusts, which is dealt with later in this chapter.

\section{B $\quad$ Adoptions, Succession and Customary Marriage}

The lack of attention paid to the effect of provisions in Māori Purposes Acts was problematic in the context of Māori customary practice. Ad hoc and discrete amendments made by Māori Purposes Acts resulted in inconsistent and poorly conceived changes in policy that failed to be fully considered either because there was minimal debate or the particular provision was not singled out for comment, resulting from the washing-up characterisation. ${ }^{253}$

The Native Purposes Act 1940 deemed customary marriages valid for the purpose of adoptions, and retrospectively validated orders of adoption made under the 1909 and 1931 Native Land Acts. ${ }^{254}$ This

\footnotetext{
248 A "Native" was defined as a person of the aboriginal race of New Zealand of at least half blood: Native Land Act 1931, s 2 .

$249 \quad$ Native Purposes Act 1943, s 3 and Native Purposes Bill 1943 (29-1) explanatory note, cl 3. This provision was later expanded: Maori Purposes Act 1947, s 16.

$250 \quad$ Native Land Act 1931, Part VIII. See petition of Riri Piko, below n 449.

251 Native Purposes Act 1943, s 5, as amended by the Committee: Native Purposes Bill 1943 (29-2) (select committee report), cl 5 .

252 Compare the Servicemen's Settlement and Land Sales Act 1943, Part II.

253 For a history of changing succession provisions, see Law Commission Māori Custom and Values in New Zealand Law (NZLC SP9, 2001) at 104-122.

$254 \quad$ Native Purposes Act 1940, s 3.
} 
provision was enacted in response to the Supreme Court decision Tutua Teone v Tipene, ${ }^{255}$ which held a legal marriage was required for the purpose of an adoption under the Adoption of Children Act 1895. The Department was concerned the principle could be applied to adoptions under the Native Land Act because customary marriages were not legally recognised, which would prevent an adopted child from inheriting from his or her adoptive parents. ${ }^{256}$ The provision was not debated before the House. ${ }^{257}$

A machinery provision in the Native Purposes Act 1941 empowered the Native Land Court to make adoption orders in respect of Māori children in favour of "mixed marriage" couples with retrospective effect so pending applications could be dealt with under the new provision. ${ }^{258}$ This provision remedied an oversight. The principal legislation contemplated a husband and wife making a joint application for adoption but the Court's jurisdiction was restricted to orders in favour of Māori applicants, ${ }^{259}$ and no order could be made in respect of a Māori child under the general law. ${ }^{260}$ This provision was not debated before the House or amended by the Committee. The provision rectified a law that did not accommodate the social reality of mixed marriages, a change that was undoubtedly important to families affected. The 1941 provision was amended the following year to remedy an obvious drafting error. ${ }^{261}$

A provision altering succession laws in the Maori Purposes Act 1949 illustrates the lack of attention paid to the content of the legislation, which was not debated. The Act empowered the Māori Land Court to grant widowers of Māori women who had died intestate an absolute or lesser interest in her real or personal estate if the widower had contributed to her property or increased the value of her estate and had not been adequately compensated. Despite being described as providing for "special circumstances"262 the provision gave the Court an unfettered ability to make such orders if "just and equitable" to do so. ${ }^{263}$ The power was not restricted to awarding life interests in respect of the deceased's land, which would have been consistent with a provision permitting orders for the maintenance of widows in the principal legislation at that time. ${ }^{264}$ And although Māori customary marriages were not recognised in principal legislation, ${ }^{265}$ the provision recognised customary marriage for the purpose of

[1936] NZLR 642 (SC). See below nn 397-412.

See Native Purposes Bill 1940 (32-1) (explanatory note), cl 3.

For examples of difficulties encountered in respect of adoptions see Māori correspondence held by National Archives: ACIH 16036 MA1/23 (1/15).

Native Purposes Act 1941, s 3.

Native Land Act 1931, ss 203 and 204.

Native Land Act 1931, ss 202(3).

Native Purposes Act 1942, s 3.

Maori Purposes Bill 1949 (68-1) (explanatory note), cl 19.

Maori Purposes Act 1949, s 19.

Native Land Act 1931, s 177(1)(a).

Native Land Act 1931, Pt XI. 
these particular orders. The provision resulted in different entitlements for widows and widowers, and exposed Māori land interests to permanent alienation. This provision created a significant exception to the principal legislation yet it was not debated. The provision did not survive long, as it was repealed when the Maori Affairs Act 1953 was enacted. Family protection provisions in the 1953 Act focused on maintenance and orders in favour of spouses were restricted to life interests. ${ }^{266}$

The Maori Purposes Act 1950 enabled the Māori Land Court to confer a new name on an adopted child. ${ }^{267}$ Magistrates dealing with the adoption of European children had been given that power decades earlier. ${ }^{268}$ This oversight was brought to the attention of the Department on behalf of Māori some years earlier as "a considerable amount of embarrassment" had been caused to Māori who needed birth certificates to establish their identity, but could not obtain certificates in their legal name. ${ }^{269}$ This provision was one of a number of amendments in the Bill categorised as being of the "usual kind" from which the important provisions in the bill were distinguished. ${ }^{270}$ Although the provision was minor in comparison to largescale policy changes implemented by that Act, it was an important change that ensured adopted Māori children were treated the same as European children. The explanation that the provision was a clause "to regularize what normally takes place in any event" failed to acknowledge the disparity between Europeans and Māori that had persisted for decades and dismissed the implications of the oversight for Māori. ${ }^{271}$

The Maori Purposes Act 1951 repealed legislative provisions allowing for or recognising Māori customary marriage. ${ }^{272}$ Despite the Minister's acknowledgement 'those who know the Maori people know that those customary unions have been as binding as, if not more binding than, many European marriages" retention of customary marriage within the legal system was considered to be causing succession difficulties. ${ }^{273}$ The government's solution was to get rid of the "special dispensation" that allowed Māori to marry without observing all formalities under the Marriage Act $1908 .{ }^{274}$ The provision preserved the legal position in respect of customary marriages entered into prior to 1 April 1952, but otherwise customary marriages would not be legally recognised. This amendment reversed the 1940 and 1949 provisions recognising customary marriage for adoption and succession claim purposes, which

\footnotetext{
266 Maori Affairs Act 1953, ss 118-123 and Schedule.

$267 \quad$ Maori Purposes Act 1950, s 13.

268 Adoption of Children Act 1895, s 12 and Infants Act 1908, s 21.

$269 \quad$ Letter to Under-Secretary, 3 August 1945: National Archives, above n 257.

$270 \quad$ (29 November 1950) 293 NZPD 4722.

271 Maori Purposes Bill 1950 (118-1) (explanatory note), cl 13. See Native Land Act 1909, Pt IX and Native Land Act 1931, Pt IX.

272 Maori Purposes Act 1951, s 8. See also above n 253, at 122-127.

$273 \quad$ (5 December 1951) 296 NZPD 1358.

$274 \quad$ Maori Purposes Bill 1951 (110-1) (explanatory note), cl 8.
} 
meant the provision enabling the Māori Land Court to award spouses a life interest would be restricted to formally married couples. ${ }^{275}$ The Bill was not fully debated, however the Member for Southern Māori expressed his view that the amendment was a "reasonable approach" to the problems arising from customary marriages. ${ }^{276}$

\section{Significant Government Policy}

A number of Māori Purposes Acts in the 1940s and 1950s implemented significant new government policies, which were often acknowledged as such.

The Native Purposes Act 1947 altered the term "Native" to "Maori" in all New Zealand legislation and across institutions, which was acknowledged to be an important change because it removed any stigma associated with the term "native" and was said to be welcomed by Māori. 277 The Maori Purposes Act 1949 contained new provisions ensuring Māori servicemen settled on land by the Board of Māori Affairs were entitled to apply for review of their liabilities. ${ }^{278}$ The rehabilitation of servicemen was a government priority at this time, and the Department was focused on ensuring Māori servicemen received the same benefits as European servicemen, a focus this provision reflected, filling a gap in policy. ${ }^{279}$ These provisions remained in force for many decades. ${ }^{280}$

The Maori Purposes Act 1950 contained whole parts introducing new policy, providing for compensation to lessees for improvements to land and dealing with unproductive Māori land. These provisions sat within the Maori Purposes Act 1950 but were deemed to form part of the Native Land Act $1931{ }^{281}$ These well-known provisions were recognised as "very important policy changes" at the time, reflecting the government's concerns about utilising land to ensure the prosperity of the country, but were the subject of minimal debate. ${ }^{282}$ These policy provisions were subsequently incorporated in the Maori Affairs Act 1953 with amendments. ${ }^{283}$ The unproductive land provisions were later repealed by the Maori Purposes

\footnotetext{
$275 \quad$ Maori Purposes Act 1951, s 8.

$276 \quad$ (5 December 1951) 296 NZPD 1359.

277 Maori Purposes Act 1947, ss 2-10. See Maori Purposes Bill 1947 (79-1) (explanatory note), cl 2 and Department of Maori Affairs “Annual Report of the Under-Secretary for the year ended 31 March 1948” [1948] V AJHR G9 at 2.

$278 \quad$ Maori Purposes Act 1949, ss 2-11.

279 Butterworth and Young, above n 26, at 86-88.

$280 \quad$ Maori Purposes Act 1949, ss 2-11, repealed by the Rehabilitation Act Repeal Act 1991.

$281 \quad$ Maori Purposes Act 1950, Parts II and III.

282 (29 November 1950) 293 NZPD 4722-4731. See Butterworth and Young, above n 26, at 95-96; Hill, above n 51, at 30-34.

283 See Maori Affairs Act 1953, Pts XX and XXV.
} 
Act 1970 due to infrequent use and Māori dissatisfaction that there was no equivalent provision dealing with "idle" European lands. ${ }^{284}$

The Maori Purposes Act 1980 contained legislative authority for the establishment of Kōkiri Centres by the Maori Land Board, ${ }^{285}$ a key component of the Department's Tu Tangata policy established following consultation with Māori. ${ }^{286}$ Kōkiri centres were community-based centres providing training and teaching skills to Māori, including in Māori language, customs and traditions. ${ }^{287}$ When established, Kōkiri centres were described as being of "vital importance" to Māori youth. ${ }^{288}$ The Maori Purposes Act 1993 provided for the cancellation and sale of Kōkiri centres without objection from the Opposition, which considered the need for Kōkiri centres had passed. ${ }^{289}$

The Māori Purposes Act 1993 was also used to implement a policy decision to cancel contracts entered into pursuant to the Mana Enterprises Scheme, a programme established in 1985 to provide business financing and employment opportunities for Māori. ${ }^{290}$ Termination of the scheme reflected changes in political ideology, with a new government favouring a different approach to assisting Māori by devolving authority to Māori, together with mainstreaming of assistance to Māori. ${ }^{291}$ The provision was considered in the House, and the Opposition's apparent comfort with these changes perhaps reflected its philosophical preference for greater devolution of authority to Māori to facilitate self-determination. ${ }^{292}$

\section{A Establishment of Māori Trusts}

The Native Purposes Act 1943 empowered the Native Land Court to vest Māori land in trustees and to declare the terms of such trusts. It is doubtful that earlier legislative provision in force for a limited period, which permitted the establishment of Māori trusts such as Wi Pere Trust, was enacted for widespread use. ${ }^{293}$

$284 \quad$ Maori Purposes Act 1970, s 6. See (12 November 1970) 370 NZPD 4912-4913.

285 Maori Purposes Act 1980, s 5.

286 Department of Maori Affairs "Report of the Department of Maori Affairs, the Maori Land Board and the Maori Trustee for the year ended 31 March 1981” [1981] II AJHR E13 at 3; Butterworth and Young, above n 26 at 112 115; Hill above n 51, at 191-199.

287 Above n, at 10-12, and Hill, above n 51, at 191.

$288 \quad$ (7 November 1980) 435 NZPD 4830. Maori Purposes Act 1993, ss 13-17. See (1 July 1993) 536 NZPD 16537 and (21 September 1993) 438 NZPD 18132. Maori Purposes Act 1993, ss 2-12 and (1 July 1993) 536 NZPD 16535-16537. See Hill, above n 51, at 204-205. See "Report on Options for Mainstreaming Mana Enterprises", 7 September 1992: National Archives, AAFH 6790 W5510/506 (SS-6-1-MAO-6) and Hill, above n 51, at 247-252.

292 See Hill, above n 51, at 206-207.

293 See Alan Dudley Ward "The History of the East Coast Maori Trust" (MA thesis, Victoria University of Wellington, 1958) at 209-210. 
The 1943 provision was described as necessary to deal with large numbers of owners of Māori land, and Hatoi No 1 Block was cited as an example. ${ }^{294}$

The successors to Hatoi No 1 Block wanted to establish a tribal reserve and lease part of the land, applying the rent to tribal purposes. A native reservation under the principal Act was ruled out because native reservations were intended for smaller areas of land and would not meet the owners' wishes due to restrictions on "ordinary dealings with land." 295 Only leases and licences for less than seven years were permitted, subject to the consent of the Court. The Department and Native Minister supported the idea of land being vested in trustees for tribal purposes with the ability to lease land for longer periods. It was agreed a new legislative provision should be drafted to enable that objective to be achieved without all the restrictions accompanying tribal reservations. ${ }^{296}$ The provisions were expected to provide a solution for land ownership in other situations, such as settlement of the Wairahi claim. ${ }^{297}$

The legislation stipulated the variety of purposes for which a trust could be established, including the "common use of the land" by Māori for any purpose, or for the support or education, physical, social, moral, or pecuniary benefit of Māori. More broadly, a trust could be established also for the benefit or welfare of Māori or the promotion of a tribal or communal project. The Native Land Court was required to be satisfied the majority of owners consented to the establishment of a trust. Trusts were subject to the oversight of the Native Minister. The vesting order of the Court could not take effect until approved by the Native Minister, and any variation or dissolution of the trust required the Minister's approval. Powers of land alienation were vested in the trustees. The exercise of those powers did not require the consent of beneficiaries, but required the Minister's approval and confirmation by the Court. Ministerial approval was also required for any expenditure other than rates, mortgage payments and taxes. ${ }^{298}$

As indicated earlier in this chapter, the 1943 Bill was characterised as insignificant and the Committee's review was considered sufficient scrutiny. ${ }^{299}$ No mention was made of the new policy provision permitting trusts to be created. The Department's annual report did acknowledge the importance of the

\footnotetext{
$294 \quad$ Native Purposes Bill 1943 (29-1) (explanatory note), cl 8.

295 Memorandum, Under-Secretary to Registrar, 28 July 1942, and Memorandum to Native Minister, 21 September 1942: National Archives, ACIH 16036 MAW 2459/237 (21/3/100).

296 Memorandam, 21 September 1942, above n, and Memorandum, Under-Secretary to Registrar, 13 November 1942: National Archives, above n.

297 Memorandum, Under-Secretary to Native Minister, 9 July 1943: National Archives, above n 295 . See chapter 7.

$298 \quad$ Native Purposes Act 1943, s 8.

$299 \quad$ Above n 243.
} 
clause, together with a corollary provision enabling trusts of Crown land to be declared for the benefit of Māori. ${ }^{300}$

In 1951 the provision was amended, empowering the Māori Land Court to revest the land in beneficial owners on dissolution of a trust, which had not been provided for. ${ }^{301}$

The 1943 provision was replaced by section 438 of the Maori Affairs Act 1953. Several key changes were made including reduced Ministerial oversight, notably in respect of alienations, and the consent of the majority of beneficial owners to the establishment of the trust was dispensed with. The Māori Land Court was authorised to establish trusts unless beneficial owners had a "meritorious objection". Section 438 trusts became very popular as a form of communal land ownership despite being used to effect subdivisions and sales. ${ }^{302}$ Section 438 was amended many times by Māori Purposes Acts.

The first amendment was controversial, allowing the Court to create section 438 trusts not just for the benefit of Māori, but for any European owners of the land who had found their way onto the land title. ${ }^{303}$ The provision was intended to prevent Europeans from "sabotaging" the creation of Māori trusts, an amendment prompted by a situation that had arisen in the Taupō area. ${ }^{304}$ The Department viewed section 438 as "beneficent" and thought Māori would suffer if obstructed from establishing these trusts. ${ }^{305}$ However, Opposition Members who were on the Committee expressed concerns about interfering with the principle that Māori trusts should be for the benefit of Māori only, and questioned whether there would be unforeseen consequences of enacting a "blanket clause" to deal with specific situations. ${ }^{306}$ The Minister of Māori Affairs maintained the clause was in the interests of Māori, but did not want to proceed without the support of all Committee members and invited further discussion. ${ }^{307}$ The provision was enacted subsequently without change. ${ }^{308}$

$300 \quad$ Native Department “Annual Report of the Under-Secretary for the year ended 31 st March 1944” [1944] II AJHR G9 at 3 .

Maori Purposes Act 1951, s 6.

Report of Royal Commission, above n 226, at 29-30. See Boast, Finn, and Spiller, above n 57, at 176. For use as an instrument of alienation see McHugh, above n 51, at 424. McHugh has acknowledged that "for the most part section 438 has been used positively and desirably": PG McHugh "The Alienation of Maori Land under Part XXIII and Section 438 of the Maori Affairs Act 1953" (1979) 10 VUWLR 153 at 171.

Maori Purposes Act 1961, s 9.

See (28 November 1961) 329 NZPD 3811-3812.

For example, see Letter, Hunn to Minister of Maori Affairs, 27 November 1961: National Archives, AAVN 869 W3599/239 (54/18/2).

Above n 304, at 3813-3815 and 3818.

Above $\mathrm{n}$ 304, at 3821. The Committee was divided over the provision: Minutes of Maori Affairs Committee, Meeting 22 November 1961: National Archives, ABGX 16127 W3706/12 (1961-1966).

Maori Purposes Act 1961, s 9. Compare the Maori Purposes Bill 1961 (126-2) (select committee report), cl 9. 
Accounting requirements were subsequently established, ${ }^{309}$ and the requirement of Ministerial consent to the establishment of trusts was repealed because the popularity of section 438 trusts had created a burden on the Minister's office. ${ }^{310}$

Section 438 was amended again in 1965 and 1966 following Court decisions.

The Māori Land Court's authority to authorise a section 438 trust that permitted lands to be transferred to trustees for the purpose of subsequent transfer to a local authority was challenged. ${ }^{311}$ The transfer was required to create public reserves so a subdivision sought by Māori could proceed. The Court of Appeal held that the orders creating the trust were invalid because section 438 contemplated trusts where land was held on trust, not disposed of, and transfer of land to the local authority was not for the benefit of owners as contemplated by section 438. This decision was considered problematic by the Chief Judge and Secretary of Māori Affairs due to the number of trusts that could be invalidated. ${ }^{312}$ Immediate action was taken with the drafting of legislative provision to cure the "defect" in what was described as the "most effective piece of machinery in the 1953 Act for the administration of Maori land". 313 Provision was added to the Maori Purposes Bill 1966 by supplementary order paper and enacted with the support of the Committee. ${ }^{314}$ The amendment specified that section 438 trusts could be established for the direct or indirect benefit of any Māori, descendant of a Māori, or any owner of Māori freehold land or European land owned by Māori, and trustees could be authorised or directed to manage land for any purpose, including subdivision and alienation. ${ }^{315}$ Māori Land Court orders made under section 438 were declared valid, together with all trustee actions, with the exception of matters before the Supreme Court, Māori Appellate Court, or Court of Appeal. ${ }^{316}$

Maori Purposes Act 1963, s 12.

Maori Purposes Act 1965, s 6. See Maori Purposes Bill 1965 (115-1) (explanatory note), cl 6 and (20 October 1965) 345 NZPD 3672. Removal of the Minister's consent had previously been suggested by the Chief Judge: Letter, Hunn to Minister of Maori Affairs, 27 June 1961: National Archives, above n 305.

Hereaka $v$ Prichard [1967] NZLR 18 (CA).

Letter, Secretary to Minister of Maori Affairs, 19 October 1966, and Letter, Prichard to Secretary, 17 October 1966: National Archives, above n 305.

See undated notes about proposed supplementary order paper: National Archives, above n 305.

Supplementary Order Paper 1966 (30) Maori Purposes Bill 1966 (114-1). See (18 and 19 October 1966) 349 NZPD 3408-3409 and 3459-3460.

Maori Purposes Act 1966, s 6(1)-(1A).

Maori Purposes Act 1966, s 6(2) and (3). 
The earlier Supreme Court decision had also prompted legislative provision, ${ }^{317}$ which empowered the Māori Land Court to set aside land to create public reserves as part of a partition order as required by a local council. ${ }^{318}$

Section 438 was subsequently rewritten by the Maori Affairs Amendment Act 1967, but the core policy changes made to section 438 by Māori Purposes Acts were retained. ${ }^{319}$ When the legal framework governing Māori land law was reformed by Te Ture Whenua Maori Act 1993 the trust concept was recognised as the means of "wise administration" of assets for the benefit of the group, reflecting rangatiratanga. ${ }^{320}$ A much wider range of trusts was provided for, and section 438 trusts became ahu whenua trusts. $^{321}$

The importance and success of the trust as a means of communal ownership, despite its potential for alienating land under the Maori Affairs Act 1953, is demonstrated by the longevity and popularity of the trust. Although the trust concept proved to be much more important than appreciated at the time the provision was enacted in 1943, it was enough of an innovation at that time to require proper consideration before the House to ensure the policy achieved what was intended. Subsequent amendments received more attention from the House due to their controversial nature.

\section{B Māori Incorporations}

Between the late 1950s and 1980s, Māori Purposes Acts frequently made alterations to the legal framework governing Māori incorporations. Some of these provisions were relatively minor such as a provision enabling the Māori Land Court to alter or redefine the objects of an incorporation established under the Maori Affairs Act 1953, ${ }^{322}$ a power omitted from the principal legislation. Other examples of minor provisions included clarification of process relating to re-election of committee of management members, ${ }^{323}$ amending provisions governing the appointment of committees of management, ${ }^{324}$ and dealing with voting by proxy. ${ }^{325}$

\footnotetext{
$317 \quad$ Hereaka $v$ Prichard and Others [1965] NZLR 302 (SC).

$318 \quad$ Maori Purposes Act 1965, s 3.

319 Maori Affairs Amendment Act 1967, s 142.

320 New Zealand Maori Council "Kaupapa: Te Wahanga Tuatahi” (February 1983) at 5, 7 and 11. See also Maori Affairs Bill 1987 (124-1) (explanatory note) at xxxiv.

$321 \quad$ Te Ture Whenua Maori Act 1993, s 354.

$322 \quad$ Maori Purposes Act 1958, s 5.

$323 \quad$ Maori Purposes Act 1958, s 6.

324 Maori Purposes Act 1960, s 8.

$325 \quad$ Maori Purposes Act 1963, s 9.
} 
Other amendments were significant, some of which were appropriately recognised as such and secured the attention of the House. Two examples are considered below.

\section{$1 \quad$ Rights of appeal}

The Maori Purposes Act 1959 restored rights of appeal against orders of the Māori Land Court in respect of incorporations; rights omitted from the Maori Affairs Act 1953 due to concerns litigation over membership of committees of management depleted assets and obstructed management of incorporations. ${ }^{326}$ Litigation in respect of Mangatu Incorporation prompted restoration of these rights, with the exception of orders of incorporation, to enable further proceedings to be taken. Restoration of these rights was acknowledged as important and was widely discussed in the House. Despite concerns the provision would encourage litigation, Members recognised Māori should not be prevented from having the right to pursue appeals as Europeans would. ${ }^{327}$

\section{Introduction of investigations}

Amendments in 1965 were described as "two of the most important provisions to be introduced in the history of Maori incorporations". 328 The legislation inserted a new provision in the Maori Affairs Act 1953 requiring Māori Land Court registrars to refer the audited financial accounts of incorporations to an examining officer if the incorporation occupied or managed land as a farm, agricultural or pastoral business. If cause for concern was identified, such as excessive expenditure or mismanagement, a registrar was required to put the examining officer's report before the Court, which could require a written explanation from the committee of management and hold an inquiry if necessary. The Court was given extensive powers to remove and replace members of the committee, impose restrictions and conditions on the operation of the incorporation, give directions as to the conduct of business, or wind up the incorporation. The Court was also able to require an investigation on the application of beneficial owners of the land. ${ }^{329}$

The provision was prompted by concerns that some incorporations were being poorly managed. Although the provision was based on the Companies Act 1955 provision, the Government considered the reluctance of owners "to move against the members of the committee of management" necessitated

\footnotetext{
326 Maori Purposes Act 1959, s 22. Compare Native Land Act 1931, ss 61 and 382(4) with Maori Affairs Act 1953, ss 42 and 272.

$327 \quad$ (14 and 15 October 1959) 321 NZPD 2449, 2458-2459 and 2462-2463.

$328 \quad$ (20 October 1965) 344 NZPD 3670.

$329 \quad$ Maori Purposes Act 1965, s 4.
} 
intervention from outside the incorporation. ${ }^{330}$ The New Zealand Māori Council initially advocated that investigations should be triggered by owner complaints, but later conceded there was a need for investigations to be commenced by an "independent outsider". ${ }^{331}$ Incorporations were concerned about liability for the cost of investigations and wanted owners to be given notice after the initial examination and before a hearing. ${ }^{332}$ The Committee amended the provision to ensure the initial investigation was excluded from any costs award. ${ }^{333}$ The provision was debated before the House, and despite concerns about the extent of consultation with Māori, there was general acceptance the provision was necessary. ${ }^{334}$ The provision was subsequently incorporated within the Maori Affairs Amendment Act 1967. 335

The Maori Purposes Act 1965 also removed a lending restriction to enable the Maori Land Board to provide more finance to Māori, including Māori incorporations. ${ }^{336}$ This change was viewed as necessary for Māori incorporations to achieve their potential. ${ }^{337}$

The Maori Purposes Act 1970 amended the investigation process, which the government acknowledged Māori resented. ${ }^{338}$ The new provision provided that investigations would only be triggered by shareholders following a general resolution or on the Court's own motion if sufficient cause existed, in line with Companies Act provisions. ${ }^{339}$

\section{Responses to Māori Affairs Amendment Acts}

The Maori Affairs Amendment Act 1967 made significant changes to the Māori incorporation framework. Incorporation lands ceased to have Māori land status and the legal and equitable estate in land was vested in incorporations, with owners holding only shares in the incorporation. ${ }^{340}$ Māori Purposes Acts were subsequently used to make a number of adjustments to the 1967 policies,

\footnotetext{
330 Memorandum, Secretary of Maori Affairs to Minister Maori Affairs, 28 September 1964: National Archives, ABJZ 869 W4644/28 (13/0/2).

331 Te Kaunihera Maori, New Zealand Maori Council Newsletter, April 1965, at 4-5: National Archives, above n.

332 Maori Incorporations of the Wairoa-Gisborne area "Submission to Maori Affairs Committee" 13 October 1965: National Archives, above n 330.

333 Maori Purposes Bill 1965 (115-2) (select committee report), cl 4. See also Letter, Under-Secretary to Minister of Maori Affairs, 14 October 1965: National Archives, above n 330.

334 (20 October 1965) 344 NZPD 3670-3672.

$335 \quad$ Maori Affairs Amendment Act 1967, s 61.

$336 \quad$ Maori Purposes Act 1965, s 8.

$337 \quad$ (20 October 1965) 344 NZPD 3671.

$338 \quad$ (12 November 1970) 370 NZPD 4913.

339 Maori Purposes Act 1970, s 10. See Companies Act 1955, ss 168-169.

$340 \quad$ Maori Affairs Amendment Act 1967, ss 31 and 32.
} 
encompassing the investigation process, ${ }^{341}$ dealing with shareholders and share transfers, ${ }^{342}$ the application of revenues, ${ }^{343}$ allowing amalgamation orders ${ }^{344}$ and trusts, ${ }^{345}$ and the winding up of incorporations. $^{346}$

The Maori Affairs Amendment Act 1974 introduced further policy changes to the incorporation framework, enabling the Court to revert the status of lands to Māori freehold land on the application of incorporations, and enabling the owners to choose whether lands would have Māori freehold land or European land status on the establishment of an incorporation. ${ }^{347}$ This policy was reversed the following year by the Maori Purposes Act 1975, which converted all lands held by incorporations to Māori freehold land status. ${ }^{348}$ The change was significant because of the protections and restrictions triggered by the change in land status. The provision did not directly address how reversion of land status was intended to fit with other provisions of the Maori Affairs Amendment Act 1967, causing interpretive problems. ${ }^{349}$

The 1975 legislation provides a rare example of overt disagreement between members of the Committee during deliberation in the House, reflecting different philosophies between political parties as to Māori autonomy and land management. The Opposition questioned the further change in policy and quality of consultation with Māori, arguing Māori incorporations had lobbied for choice as to land status the previous year. The government defended the change as reflecting its electoral promise to restore the status of lands prior to the Maori Affairs Amendment Act 1967, stating the change was consistent with Māori land retention and respected the connection of Māori with their land. ${ }^{350}$

\section{Conclusions}

Māori Purposes Acts contained many genuine machinery, technical and administrative provisions, which were not significant extensions of policy requiring intensive scrutiny by the House and fell within the

\footnotetext{
$341 \quad$ Maori Purposes Act 1968, s 7.

342 Maori Purposes Act 1969, s 7, Maori Purposes Act 1970, s 8, Maori Purposes Act 1971, s 2, Maori Purposes Act 1975, s 7 and Maori Purposes Act 1977, s 4.

$343 \quad$ Maori Purposes Act 1976, s 16.

$344 \quad$ Maori Purposes Act 1970, s 9.

345 Maori Purposes Act 1975, s 8.

346 Maori Purposes Act 1971, s 3.

347 Maori Affairs Amendment Act 1974, s 77.

348 Maori Purposes Act 1975, s 17. For further amendments see Maori Purposes Act 1977, s 5 and Maori Purposes Act 1978, s 7.

349 Sadlier v Fitzsimmons \& Ors - Anaura Inc (2006) 32 Tairāwhiti Appellate MB 342 (32 APGS 342 ).

$350 \quad$ (10 September 1975) 401 NZPD 4315-4320 and (7 October 1975) 402 NZPD 5252-5259. See Minutes of Maori Affairs Committee, Meeting 1 October 1975: National Archives, ABGX 16127 W3706/12 (1975-1977).
} 
concept of "washing-up". However, as Llewellyn's law-jobs theory highlights, such provisions should not be assumed to be unimportant, which would ignore the role such provisions played in keeping the legal system functioning. Relatively minor amendments and non-controversial adjustments of government policy were also characterised as "washing-up" measures and did not receive attention in the House. This approach also overlooks the effect of such provisions. Provisions characterised as minor could have significant impact on the lives of Māori, perhaps best illustrated by the need for a provision enabling adopted Māori to obtain birth certificates in their legal name, the inability to do so having caused embarrassment and distress in that time period.

Māori Purposes Acts were not restricted to innocuous or relatively minor amendments or machinery provisions. The Acts were used to introduce significant policy changes, fill policy gaps, and correct oversights, often due to dissatisfaction with the effects of the principal legislation. Provisions responded to Court decisions, implemented changes in government policy, dealt with specific problems, and in some cases, responded to Māori discontent. Occasionally, Māori Purposes Acts were used to introduce larger-scale policy changes. Incremental changes to principal legislation created inconsistencies within the legal framework and undermined key policies in principal legislation. Some provisions were motivated by considerations of social equity, but many provisions were reactive and ad hoc responses to particular problems, rather than being principled changes.

While some Māori Purposes provisions were recognised as important and were not represented as "washing-up" measures, more often than not, important changes were mischaracterised and failed to attract the attention of the House. Important policy changes were passed into law by the same hurried process intended to apply only to minor, machinery and administrative provisions. Failure to appreciate the significance of many of these provisions, in combination with short timeframes and limited insight that principal legislation was a poor fit for Māori, meant little consideration was given to these provisions or their impact on Māori. Although the Committee did make some positive changes to Māori Purposes Bills, there is little evidence to suggest the Committee regularly took issue with the content of the Bills or was able to resist government policy. Māori Purposes Acts, as a body of legislation, do not serve as an example of good legislative practice.

Many policy and amendment provisions in the legislation fall within the ambit of Llewellyn's second law-job of producing and maintaining the legal framework for the benefit of a group, although it is difficult to see how constant changes to the legislative framework were of benefit to either Māori or New Zealand society given the instability and uncertainty created. However, the reactive and ad hoc nature of many amendment and policy provisions suggest these provisions are better understood as responding to trouble-cases, which fall in the realm of Llewellyn's first law-job. Such provisions attempted to fix problems caused by a legal framework that did not adequately accommodate the Māori way of life and 
customs, a disconnect Llewellyn warns against. Māori Purposes Act provisions are evidence of a legal system that was without doubt "mis-firing" if not on the brink of collapse. 


\section{Chapter 6: Petitions}

\section{Overview}

This chapter examines the relationship between Māori petitions to Parliament and Māori Purposes Acts, primarily between 1933-1951, the period in which Māori Purposes Acts were still dominated by "claims" provisions, reflecting the origins of this "washing-up" legislation. ${ }^{351}$ I focus on provisions included in Māori Purposes Acts as the direct result of petitions. Petitions relating to tribal and other claims against the Crown that resulted in settlement or remedial provisions incorporating an element of compensation are addressed in the next chapter.

Petitions by Māori in the late $19^{\text {th }}$ century predominantly related to Māori land issues and the Native Land Court, with most comprising private land grievances. ${ }^{352}$ During the period 1933-1951 most petitions that resulted in provisions in Māori Purposes Acts also related to land-based problems, and were of an individual or private nature. Petitions included claims against the Crown resulting from errors in the course of acquisition of lands, claims for wrongful confiscation, claims relating to fishing rights and in respect of reserves and burial grounds, and claims relating to wider Māori land management problems. Many petitions related to ownership interests, succession and estate difficulties caused by the legal framework governing Māori land. ${ }^{353}$

Provisions in Māori Purposes Acts resulting from petitions represent the minority of petitions that progressed through the Parliamentary system and for which some legislative response was obtained. My analysis offers a window of insight into the petitions process. The petitions process required a petitioner to have exhausted all available legal remedies before seeking assistance from Parliament, and outcomes depended on subjective assessments of claims based on fairness. Although there were common themes between petitions, outcomes were often fact-specific and unpredictable. I have chosen examples to illustrate pathways from petition to legislative provision, incorporating varying subject-matters and outcomes. The question of whether provisions achieved justice for Māori will be considered.

351 The Native Purposes Act 1931 was primarily a consolidation of existing provisions. There was no Native Purposes Act in 1932.

$352 \quad$ Above $\mathrm{n}$ 68, at 9 and 12-13.

353 These observations are based on analysis of the Committee's annual reports to the House during the period 19331951. 


\section{Process}

Petitions from Māori or relating to Māori matters were referred to the Committee. It was the Committee's practice to seek a report from the Department together with any relevant information it held. ${ }^{354}$ Some petitions were dealt with solely on the basis of the petition and the Department's report, while in other cases the Committee heard evidence from the petitioner and opposing parties. ${ }^{355}$ The Committee frequently had "no recommendation" to make, sometimes because the petitioner was yet to exhaust his or her legal remedies or because the petition had not been prosecuted, and the Committee declined to deal with matters of government policy. In many cases no explanation was given. Petitions that received "no recommendation" did not proceed further, although this did not mean the petitioner or grievance did not persist. ${ }^{356}$

Petitions supported by the Committee were either recommended for consideration by government or for an inquiry by the Māori Land Court. If the House supported the Committee's recommendation the report would be ordered referred to government. ${ }^{357}$ One of the acknowledged limitations of New Zealand's petitions process was the absence of any obligation on the government to respond to recommendations of select committees until 1967,, ${ }^{358}$ which meant nothing was done in respect of many petitions recommended for further action.

\section{Recommendations for Favourable Consideration}

Petitions referred to government for consideration were often endorsed with recommendations for "favourable" or "most favourable" consideration. A comparison of the annual reports of the Committee between 1933 and 1951 with Māori Purposes Acts indicates that approximately 44\% of petitions recommended to government for favourable or most favourable consideration resulted in provision within Māori Purposes Acts. ${ }^{359}$

This observation is based on review of National Archives files and minute books of the Committee.

For example, this can be observed in the Native Affairs Committee Minute Book 1936: National Archives, AEBE 18507 LE1/1103 (1936/16).

This analysis is based on annual reports of the Committee contained in Appendices to the Journals of the House of Representatives between 1933-1951. For a petition that resulted in an outcome regardless of receiving "no recommendation" see below nn 483-486.

This process can be observed in Journals of the House of Representatives between 1933-1951.

Harris and Wilson, above n 24, at 612.

This statistic is based on comparison of initial recommendations of the Committee with Māori Purposes Acts. 
Many provisions dealt with succession and estate issues. Provisions did not necessarily provide determinate outcomes, but provided for further procedural steps to progress claims, and often this is what was requested. For example, provisions authorised the Chief Judge of the Native Land Court to exercise jurisdiction, ${ }^{360}$ permitted appeals and authorised rehearings or inquiries not provided for by the general legislative framework. ${ }^{361}$ Several legislative provisions permitted applications for probate of wills to be dealt with by the Court out of time where delay was due to a misunderstanding or was unavoidable. ${ }^{362}$ In one case probate had not been applied for because the deceased's will could not be located due to a solicitor's absence during the war, and it was subsequently found. The provision empowered the Court to hear an application for probate of the will, and for existing succession orders to be cancelled and new orders made, subject to reasonable compensation for any initial successors who had reduced debt over the land. 363

Some provisions did deliver determinate outcomes, such as a provision rectifying an error of the Court that omitted Ngāi Tahu descendants from a list of owners, ${ }^{364}$ and a provision enabling Māori owners to participate in the administration of the East Coast Trust. ${ }^{365}$

\section{A Petition of Taite Te Tomo}

The petition of Taite Te Tomo in 1933 provides an example of a determinate legislative outcome, and illustrates the government's willingness to put right an incontrovertible error, following the advocacy of a Māori Member of Parliament.

The petition sought rectification of errors made by the Native Land Court in respect of land in Foxton. Petitioners asked for the existing land title to be cancelled and for the land to be vested in trustees, to be held as a cemetery for Ngati-Whakatere. ${ }^{366}$ Māori had previously sought the Court's intervention, by applying to the Chief Judge for an investigation. ${ }^{367}$ The Department's report to the Committee was unequivocal, stating the Native Land Court had been "plainly told" the land was to be held on trust as a burial ground, but the Court made an order in 1890 in favour of various owners without any provision For example, see Maori Purposes Act 1948, s 10 (petition 19/1947) and Maori Purposes Act 1950, s 56 (petition 6/1950).

363 Maori Purposes Act 1951, s 31 (petition 4/1951) and Maori Purposes Bill 1951 (110-1) (explanatory note), cl 31. 
for a trust. The Court then disregarded a subsequent Order-in-Council authorising investigation into whether a trust should have been provided for, and vested title in the original owners and their successors. $^{368}$

The Committee, of which Taite Te Tomo was a member, recommended the petition to government for favourable consideration. ${ }^{369}$ Legislative provision followed shortly thereafter. The Native Purposes Act 1933 cancelled the 1890 order and Order-in-Council and directed cancellation of the existing certificate of title. The Native Land Court was empowered to reserve the land for Ngati-Whakatere and to make bylaws for the management of the land, including fines for breach of those bylaws. The Court was also empowered to appoint trustees to administer the land. ${ }^{370}$ There was no explanation or discussion of the provision in the House; it was dismissed as one of the washing-up provisions. ${ }^{371}$

\section{B Petitions Relating to Te Karae Leases}

Although many legislative responses to petitions were positive for Māori, in the sense they eased legal restrictions and responded to practical problems, that was not always the case. This example illustrates the government's willingness to bypass judicial decisions it did not like and demonstrates the capacity for legislative responses to petitions to effect injustice for Māori.

Several petitions were brought by non-Māori lessees seeking a remedy for an error made by the Tokerau District Maori Land Board. ${ }^{372}$ Leases had been renewed by the Board on the understanding compensation for improvements would be paid to lessees. These transactions were challenged in a test case. The Court of Appeal ruled the original lease did not contain provision for compensation for lessees, ${ }^{373}$ and the Board could not renew the lease with provision for compensation. Lessees sought validation of renewed leases by way of petitions, which the Committee referred to government for "most favourable" consideration.

It was clearly accepted the Board had acted in error. The Department reviewed various options for redressing the problem, including compensation and exchange of lands, acknowledging the argument Māori were entitled to the unencumbered reversion of the land. The President of the Board was consulted

\footnotetext{
368 Memorandum, Under-Secretary to Native Affairs Committee, 6 October 1933: National Archives, above n 366.

369 Native Affairs Committee "Reports of the Native Affairs Committee" [1933] III AJHR I3 at 2. 
and advocated for lessees to receive "the rights they bargained for". 374 The President did not accept Māori owners might suffer loss if required to pay for the lessees' improvements, and in response to the suggestion the Board should pay for its own mistake, advised it had no money to compensate owners. ${ }^{375}$

The Maori Purposes Act 1946 provided for the validation of leases renewed by the Board on the basis compensation for improvements would be paid to lessees, and permitted the renewal of other leases on the same basis. ${ }^{376}$ There was no debate of the bill so this provision was only examined by the Committee, and no concern or objection was raised. ${ }^{377}$

The provision was a favourable outcome for petitioners, but it placed all financial risk with Māori owners who had no control over management of the land and no provision was made for the Board or Crown to account for the mistake made. This example calls the petitions process and statutory responses into question where claims involved the Crown. The Crown, as wrongdoer, held the power to decide what remedy, if any, would be provided. The financial difficulties resulting from the Board's land management, including payment of compensation for improvements, was raised in the modern Treaty of Waitangi settlement process and the Crown has accepted its actions were inappropriate. ${ }^{378}$

\section{Palmerston North Reserves}

The Palmerston North Reserves regularly featured in the Māori Purposes Acts, with provisions dealing with issues such as the status of land title and appointing a Commission to settle the ownership of the reserves. ${ }^{379}$ In 1962 some of the owners of the reserve petitioned for the right to alienate their interests to obtain the benefit of increasing land values, which was prevented by the Maori Reserved Land Act 1955. Legislative responses to the 1962 petition provide an example of poor legislative scrutiny and inconsistent policy, undermining any possibility the response could be viewed as respecting Māori selfdetermination.

\footnotetext{
374 Memorandum, Under-Secretary to Minister, 1 November 1945 and Memorandum, Under-Secretary to President, Tokerau District Maori Land Board, 18 January 1946: National Archives, above n 372.

375 Memorandum, President, Tokerau District Maori Land Board to Under-Secretary, 27 February 1946: National Archives, above n 372. See also above $n$.

$376 \quad$ Native Purposes Act 1946, s 11 and Native Purposes Bill 1946 (60-1) (explanatory note), cl 11.

377 Maori Affairs Committee Minute Book 1946, Meeting, 9 October 1946: National Archives, AEBE 18507 LE1/1277 (1946/14).

378 Te Rarawa and the Crown, Deed of Settlement of Historical Claims, 28 October 2012 at 57-61 and 86.

379 Native Purposes Act 1937, s 13 and Maori Purposes Act 1951, s 39. For a brief history of the reserve see <http://www.tekau.maori.nz/PalmerstonNorthMaoriReserveTrust/AboutUs/History.aspx>.
} 
The petition was presented in context of decreasing returns on the land and expectations the Māori Trustee was going to acquire all equitable interests over time. Many owners considered the best option was to sell to lessees, who petitioners believed were willing to buy at market value. ${ }^{380}$ A previous attempt by lessees to obtain freehold titles under a previous government had failed, despite support from beneficial owners. ${ }^{381}$

The Committee heard evidence from the petitioners. Government members passed a motion recommending the petition for favourable consideration, relying on the Chair's casting vote to obtain a majority. ${ }^{382}$ The Committee appeared to consider the fact the lands were not ancestral as a key determinant. ${ }^{383}$ When the petition was subsequently referred to government the Department wanted time to consider options and was concerned about setting a precedent. ${ }^{384}$ Ultimately the decision was made that Palmerston North Reserves could be distinguished from other reserves because the land was not significant to Māori. ${ }^{385}$

The Maori Purposes Act 1963 created an exception to the restrictions on alienation in the Maori Reserved Land Act 1955. Beneficial owners were entitled to notify the Māori Trustee they wanted to sell their interests in the reserve, and if the Māori Trustee considered the number of owners wanting to partition land justified an application to the Māori Land Court, an application was permitted. The Court was authorised to partition the land between owners who wanted to sell and those who did not, and for that purpose it was to adopt unimproved values of the lands. This was at odds with the expectation those selling would receive market values and the requirement that if partition was authorised, the Māori Trustee must sell at the price stipulated by owners. ${ }^{386}$ Relative to other Māori Purposes Bills, there was substantive debate about this provision in the House and some concern was expressed about whether petitioners represented all owners. The Opposition conceded development of Palmerston North was necessary, but Māori must receive full market value for the land. ${ }^{387}$

This process proved unworkable. It was predicated on the assumption lessees would pay market value, but when "derisory" offers to buy the land were received flaws in the process were revealed, including concerns that reliance on unimproved values to partition lands would not result in equitable outcomes. ${ }^{388}$

380 Petition 33/1962: National Archives, ABOG 869 W5004/9 (6/58/5).

381 See petition 36/1956: Maori Affairs Committee "Reports of the Maori Affairs Committee" [1958] IV AJHR I3 at 3.

$382 \quad$ Minutes of Committee, Meetings 7 November 1962 and 24 October 1962: National Archives, above n 307.

383 Note, Allen to Under-Secretary, 6 December 1962: National Archives, above n 380.

384 Letter, Under-Secretary to Minister of Maori Affairs, 6 December 1962: National Archives, above n 380.

385 Letter, Under-Secretary to Minister of Maori Affairs, 19 August 1963: National Archives, above n 380.

$386 \quad$ Maori Purposes Act 1963, s 20.

387 (17 October 1963) 337 NZPD 2567-2572.

388 Memorandum, District Officer to Department, 7 April 1964: National Archives, above n 380. 
Because more than half the owners wanted to sell, the Māori Trustee persisted with identifying a solution, but there is no record of consultation with Māori owners. ${ }^{389}$

An alternate process was added to the 1963 provision by the Maori Purposes Act 1964, which prioritised efficiency and certainty. ${ }^{390}$ Control of the process was shifted away from Māori owners to the Māori Trustee and lessees, and a binding process was created where sale prices were set at the unimproved value of the land plus $5 \%$ and commission, not market values. The solution for avoiding a partition was to reduce the total number of shares, which also eliminated the need for Māori Land Court oversight. There was no detailed discussion in the House about the problem the new process aimed to remedy, or whether the process remained true to what Māori wanted to achieve in petitioning Parliament. The Opposition was noticeably silent, only commenting that the new method would be a relief to beneficiaries as it would speed up the process. ${ }^{391}$

The legislative process undoubtedly failed Māori. The provision was subsequently amended, before the ability to sell interests in Māori reserves was entirely repealed by the Maori Purposes Act 1975 following a Commission of Inquiry. ${ }^{392}$

\section{Recommendations for Consideration}

In contrast to petitions recommended for favourable consideration, only a small number of provisions in Māori Purposes Acts resulted from recommendations for "consideration". However legislative responses achieved similar ends, such as easing restrictions contained in the general legislative framework, extending the time within which an appeal could be lodged, ${ }^{393}$ and modifying the terms governing an estate. ${ }^{394}$ Another example was a provision permitting land to be released from a Native Memoranda, Maori Trustee to Minister of Maori Affairs, 21 and 29 September 1964, and other documentation: National Archives, above n 380. Maori Purposes Act 1964, s 16. (30 October 1964) 341 NZPD 3070-3071. Maori Purposes Act 1975, ss 9-11. See Royal Commission "Report of Commission of Inquiry into Maori Reserved Land" [1975] IV AJHR H3 at 95-96 and Memorandum for Cabinet Committee on Legislation and Parliamentary Questions from Minister of Maori Affairs, 3 September 1975: National Archives, AAFD 811 W4198/91 (CAB244/1/1). For the other changes, see Maori Purposes Act 1966, s 14 and Maori Affairs Amendment Act 1967, ss 156 and 157.

$393 \quad$ Native Purposes Act 1933, s 21 (petition 305/1932-33).

$394 \quad$ Petitions in 1946 and 1951 sought changes to the estate of Pukepuke Tangiora, and resulted in legislation following recommendations for consideration: see below n 749 .
} 
reservation. $^{395}$ I have chosen two petitions for further analysis that illustrate justice is open to interpretation and perspective as Andrew Sharp has suggested. ${ }^{396}$

\section{A Estate of Teo Tipene}

Issues relating to probate and succession problems were commonly the subject of petitions, and laws governing adoptions involving Māori gave rise to many inequities and problems brought before Parliament. The petition of Robert Tipene, seeking the right to inherit from his adoptive father's valuable estate, demonstrates some of these problems in the context of extensive litigation.

Succession orders had been made in the Native Land Court in 1932 in favour of Teo Tipene's nephews and niece without Robert Tipene's knowledge. ${ }^{397}$ Robert subsequently sought to have his incomplete adoption order recognised and applied to the Chief Judge of the Native Land Court to rectify the succession orders. The Chief Judge was willing to accept an entry made in the Court's minute book as prima facie evidence of an adoption under the Adoption of Children Act 1895 and issue orders enabling Robert to succeed to his father's estate. ${ }^{398}$ The Chief Judge's powers were ruled wide enough to make such orders. ${ }^{399}$ However, subsequent legal challenge led to rulings that the adoption was not valid because a written order was not completed, ${ }^{400}$ and that, because Teo Tipene and his wife were not legally married, they were not entitled to adopt Robert. ${ }^{401}$

An attempt by Robert to then prove he was the biological son of Teo Tipene was also defeated. Although the Chief Judge of the Native Land Court was willing to accept evidence from Robert's biological mother that Teo Tipene was his biological father, ${ }^{402}$ the Native Appellate Court was not. ${ }^{403}$

Robert Tipene's petition to Parliament was the next stage of the process, and it was recommended for consideration. ${ }^{404}$ An initial legislative provision prohibited alienation of the land while the Committee

\footnotetext{
$395 \quad$ Native Purposes Act 1933, s 19 (petition 74/1933).

$396 \quad$ Above $\mathrm{n} 91$.

397 Petition 100/1937: National Archives, AAMK 869 W3074/753/d (24/2/3).

398 Memorandum of Chief Judge Jones, 13 August 1935: National Archives, above n.

$399 \quad$ Tutua Teone v Jones [1936] NZLR 494 (CA).

$400 \quad$ Tutua Teone v Tipene [1936] NZLR 642 (SC), confirmed in Tipene v Tutua Teone [1937] NZLR 1098 (CA).

$401 \quad$ Tutua Teone v Tipene, above n.

$402 \quad$ Teo Tipene (Deceased) (1937) 30 Wellington MB 17 (30 WN 17).

$403 \quad$ Teo Tipene (Deceased) (1937) 7A Wellington Appellate MB 255 (7A APWN 255).

404 Native Affairs Committee "Reports of the Native Affairs Committee" [1938] III AJHR I3 at 4.
} 
considered the petition. ${ }^{405}$ Despite the petition not being supported by all officials, ${ }^{406}$ the Native Purposes Act 1941 empowered the Native Land Court to determine whether the petitioner should receive the whole or part of the estate on the basis of fairness, and without regard to Native custom or any preceding succession order. The Court was permitted to cancel any existing order and make new orders. ${ }^{407}$ The bill was characterised as containing "miscellaneous" provisions, and despite the fact such a provision necessitated careful thought and debate in the context of existing policy and extended litigation, it was not addressed in the House other than brief mention in the Legislative Council. ${ }^{408}$

Robert Tipene was subsequently awarded the full estate on the basis he should be treated as the legally adopted son of Teo Tipene despite the technicality of the incomplete order. It was also accepted that Robert was Teo Tipene's biological son. The decision was appealed to the Native Appellate Court but was dismissed. ${ }^{409}$

The outcome for Robert Tipene was clearly favourable. However, a subsequent difficulty flowed from the legislation. The issue of improvements made to the land while it was in the ownership of Teo Tipene's nephews and nieces was not addressed in the Native Purposes Act 1941. The Court's jurisdiction was broad enough that improvements could have been accommodated, but for various reasons the issue was not brought to the Court's attention. A petition was presented in 1945 by Mary Te One seeking compensation for the value of a house built on the land, which she and her family had continued to live in, despite Robert's legal ownership, until the house was taken by the Crown for housing purposes. ${ }^{410}$ Compensation paid by the Crown for the land and improvements had been retained by Robert. Mary Te One's petition was referred for inquiry. The Chief Judge reported to the Minister a "serious injustice" had occurred and recommended Mary Te One receive the compensation for improvements paid to Robert Tipene less the rates he had paid, and that legislation charge Robert's land as security for the compensation. ${ }^{411}$ The Maori Purposes Act 1951 implemented this recommendation, which although positive, resulted in Mary Te One recovering only a portion of the money spent building the house. ${ }^{412}$

\footnotetext{
$405 \quad$ Native Purposes Act 1939, s 17.

Memorandum, Under-Secretary of Department of Justice, 21 June 1939: National Archives, above n 397. Native Purposes Act 1941, s 17. See Native Purposes Bill 1941 (33-1) (explanatory note), cl 13. (8 and 10 October 1941) 260 NZPD 1060 and 1103. See Teo Tipene, deceased (1943) 34 Wellington MB 327 (34 WN 327) and Estate Teo Tipene (1943) 6 Wellington Appellate MB 213a (6 APWN 213a). Petition 38/1945: National Archives, above n 397.

Maori Land Court "Report and Recommendation of Maori Land Court on Petition No 38 of 1945, of Mary Te One, Praying for Protection in Respect of Certain Improvements on the Land Known as Hutt Section 19, Subsection 21G" [1951] II AJHR G6A. Maori Purposes Act 1951, s 40.
} 


\section{B Petition of Ngahuia Beasley}

The petition of Ngahuia Beasley in 1943 sought relief in respect of an error made by a Crown consolidation officer. Although officials had initial reservations about the merit of her claim, Ngahuia was successful in securing a legislative remedy. Unfortunately, the legislative provision interfered with third-party property rights, casting doubt on the overall justice of the situation.

Ngahuia Beasley was sold the wrong section of land by the consolidation officer as part of a wider consolidation scheme operated by the Tokerau District Maori Land Board. The officer mistakenly believed the land was owned by his family. Ngahuia paid installments on the agreed purchase price and carried out improvements to the land before the mistake was discovered several years later. The land Ngahuia had improved was European land owned by a Māori family who lived outside the district. ${ }^{413}$

Ngahuia applied to the Native Land Court for assistance, but the owners of the land objected to the Court's intervention as it lacked jurisdiction over European land. ${ }^{414}$ The Court recommended petitioning Parliament. Ngahuia petitioned for legislative provision authorising the Court to determine her claim, or enabling her to acquire the land from the owners on payment of the agreed purchase price, with the Department paying "proper compensation" to the owners. ${ }^{415}$

A report from the Native Land Court to the Committee confirmed many factual details presented in the petition but indicated no authority had been given for Ngahuia to carry out improvements. ${ }^{416}$ In comparison, Ngahuia believed the officer's family were agreeable to the improvements being made. ${ }^{417}$ The petition was recommended for consideration with the directive the Court be empowered to hear and determine the claim on its merits. ${ }^{418}$

It was accepted an error was made by the Crown officer, who was alternately described as an officer of the Department and the Court. ${ }^{419}$ Liability on the part of the Crown was immediately ruled out without explanation. ${ }^{420}$ This likely indicates the officer was considered a judicial officer for the purpose of the

413 Petition No 87/1943: National Archives, ACIH 16036 MA1/135 (5/13/145).

$414 \quad$ See Native Land Act 1931, s 27.

$415 \quad$ Above $\mathrm{n} 413$.

416 Memorandum, Registrar to Head Office, 20 October 1943: National Archives, above n 413.

417 Undated notes, Judge Acheson re hearing on 7 October 1940, National Archives, above n 413.

418 Maori Affairs Committee "Reports of the Maori Affairs Committee" [1944] II AJHR I3 at 6.

419 Compare Memorandum of Under-Secretary to Minister, 3 October 1946, with Report of Judge Prichard, 22 May 1946: National Archives, above n 413.

420 Memorandum, Under-Secretary to Native Minister, 3 October 1946: National Archives, above n 413. 
Crown Suits Act 1908, relieving the Crown from any liability. ${ }^{421}$ The potential application of an "equitable doctrine" providing relief for mistake was also ruled out because it would have required the landowners knew about the improvements and allowed them to proceed, which was not the case. ${ }^{422}$

The government decided the petition should be dealt with under section 542 of the Native Land Act 1931, which permitted an inquiry by the Native Land Court and broad recommendations. The purpose of the process was to persuade the owners the petitioner had a moral claim against them. ${ }^{423}$ The Court valued the improvements and found that loss of the land would affect Ngahuia's existing farming operations and road access to adjacent land she and her husband occupied. The Court noted the landowners had not lived on the land or developed it, and it was not ancestral land. Attempts to negotiate a settlement with the owners failed. The Court accepted Ngahuia had acted in good faith and recommended legislative provision along the lines of a provision in the Judicature Act 1908 dealing with encroaching buildings. ${ }^{424}$ The Chief Judge endorsed the proposal, describing the case as "exceptional". 425

The Department accepted this view of the situation. ${ }^{426}$ The legislative remedy was based on the Court's recommendations and enacted without further notice to the owners of the land. The Court was empowered to determine the value of the improvements and order the owners to pay that money within three months. If payment was not made the Court was authorised to make exchange orders. If that was impractical, the Court could order a transfer of the land to Ngahuia subject to her paying twice the original purchase price to the owners. ${ }^{427}$

The landowners voiced their objection to the "injustice" of the provision, advising a petition and appeal were pending. ${ }^{428}$ The Court was asked to intervene and subsequent correspondence confirmed the matter had been "amicably settled". ${ }^{429}$ Ngahuia Beasley took ownership of the land in $1948 .{ }^{430}$

The provision ensured Ngahuia did not lose the value of her improvements and the economic viability of her farming operation was preserved, but it is difficult to view the overall outcome as being fair. Ngahuia was granted a remedy that had no parallel at that time, reflecting elements of unjust enrichment

\footnotetext{
$421 \quad$ Crown Suits Amendment Act 1910, ss 3-5.

422 Memorandum, Under-Secretary to Native Minister, 17 November 1944: National Archives, above n 413.

423 Memorandum, Chief Judge to Registrar, 26 February 1945: National Archives, above n 413.

424 Report of Judge Prichard, above n 419, at 3-4.

425 Memorandum, Chief Judge to Minister, 20 September 1946: National Archives, above n 413.

426 Memorandum, Under-Secretary to Native Minister, 3 October 1946: National Archives, above n 413.

$427 \quad$ Native Purposes Act 1946, s 12.

428 Telegram, Paikea to Native Minister, 14 January 1947: National Archives, above n 413.

429 Telegrams, Native Minister to Paikea, 14 January 1947 and 17 January 1947: National Archives, above n 413.

$430 \quad$ Auckland Land Registry, Certificate of Title 897/206.
} 
outside settled categories. It was not until 1963 that a legislative remedy for encroachment resulting from a mistake as to the identity of land was enacted. ${ }^{431}$ The landowners did no more than insist on their legal rights and the Crown accepted no responsibility for the error, which falls short of restoring balance. The factual circumstances may have been unique, but the potential injustice to Ngahuia Beasley was no more compelling than other Māori claims resulting from Crown errors.

\section{Petitions Referred for Inquiry}

Many petitions were recommended to government for inquiry or investigation, either because the petitioners requested it, or because the Committee considered an inquiry necessary. Occasionally the Committee deviated from this formula by recommending petitions be referred to a "special" tribunal or inquiry. ${ }^{432}$

Between 1933 and 1947 Māori Purposes Acts contained schedules of petitions recommended for inquiry or investigation, which were collated by the government and the Committee. ${ }^{433}$ The Chief Judge of the Native/Māori Land Court was authorised to refer the "claims and allegations made by the petitioners" to the Court, Judge or Commissioner, for inquiry and report, ${ }^{434}$ and to make recommendations to the Minister on the basis of what appeared "just and equitable". 435 The report and recommendations were required to be laid before Parliament for consideration. ${ }^{436}$

Almost two-thirds of petitions referred for inquiry by the Committee between 1933-1947 were placed in schedules to Māori Purposes Acts. ${ }^{437}$ This prompted objection from the Māori representative on the Legislative Council in 1945, who thought more petitions should have been placed in the bill that year. ${ }^{438}$ Over half of petitions placed in schedules did not progress beyond the inquiry stage, receiving "no

$431 \quad$ Property Law Amendment Act 1963, s 3 and Maori Purposes Act 1963, s 13. For mistaken improvements to land see Charles Cato Restitution in Australia and New Zealand (Cavendish Publishing, Sydney, 1997) at 40-43 and Van Den Berg v Giles [1979] 2 NZLR 111 (SC).

432 See Native Affairs Committee "Reports of the Native Affairs Committee" [1938] III AJHR I3 and Native Purposes Act 1938, ss 10 and 12-14.

This is observable in the content of schedules to Māori Purposes Bills before and after referral to the Committee. See Native Purposes Act 1933, s 27(1) and Maori Purposes Act 1947, s 55(1).

For example, see Native Purposes Act 1934, s 9(2) and Maori Purposes Act 1947, s 55(2). Reference to a Commissioner of the Native Land Court ceased from 1940. In 1933 the wording of the Court's jurisdiction differed slightly, referring to recommendations in "accord with the equities", derived from the Native Land Amendment and Native Land Claims Adjustment Acts: Native Purposes Act 1933, s 27(2).

See Native Purposes Act 1933, s 27(3) and Maori Purposes Act 1947, s 55(3).

This statistic and other statistics in this paragraph are based on comparison of initial recommendations of the Committee as contained in its annual reports and inquiry reports of the Chief Judge.

(6 December 1945) 272 NZPD 445. 
recommendation" from the Chief Judge, and some failed to progress to an inquiry at all. ${ }^{439}$ Approximately a third of petitions referred for inquiry received a recommendation that some further action be taken, including recommendations legislative provision be made to resolve or progress the issue raised in the petition. The inquiry process had the potential to take many years from presentation of the petition to legislative outcome, if any, ${ }^{440}$ and only a small number of recommendations for action resulted in further legislative provision in the Māori Purposes Acts.

The legislation allowed for further inquiry by the Māori Land Court, such as the Wakapuaka Block example considered below, or for payment of compensation, such as in the case of Wharewaka Reserve $^{441}$ and the petition of Mary Te One. ${ }^{442}$ Other provisions dealt with estate and succession issues, authorising applications for probate to be heard out of time, ${ }^{443}$ and empowering the Māori Land Court to redistribute an estate, including cancellation of existing succession orders. ${ }^{444}$ One provision authorised the Chief Judge to state a case for the Supreme Court to resolve interpretation issues arising from the translation of a will written in Māori. ${ }^{445}$

This analysis suggests very poor outcomes for Māori, although it is important to consider why inquiries failed to progress to legislative provision. Reasons included a lack of prosecution, ${ }^{446}$ and in a few cases the claim had been resolved or settled. ${ }^{447}$ Many petitions that did not progress were considered to suffer from evidential problems or to be without merit. For example, a petition from the family of Tiwai Pomare, who had been excluded from his father's will, sought an interest in lands originally belonging to Tiwai Pomare's mother that had been devised to children of his father's second marriage. The Court acknowledged hardship may have occurred, but delays, partly due to lack of prosecution, and limited

439 Most reports were published in Appendices to the Journals of the House of Representatives at G6, with unpublished reports available at National Archives, usually in the LE1 or MA/1 record groups. I was unable to locate reports for four of 81 petitions in the schedules, suggesting no inquiry was held, and no further provision was made within Māori Purposes Acts.

$440 \quad$ For example, see petition of Mary Te One, above nn 410-412.

$441 \quad$ See below n 608.

442

Above $n$ 440. For petitions relating to Pukeroa-Oruawhata, see chapter 7.

Maori Purposes Act 1949, s 25 (petition 30/1947).

Native Purposes Act 1942, s 6 (petition 344/1934-35).

Native Purposes Act 1934, s 4. Native Land Court "Report and Recommendation on Petition No 49, of 1932, of H McClutchie" [1934-35] II AJHR G6. See Re Turuhira Tuhiwai [1936] GLR 382 (SC).

This observation is based on review of reports of the Chief Judge and the Court.

See for example, Native Purposes Act 1938, Schedule cl 10 and Native Land Court "Report and Recommendation on Petition No 33 of 1938, of Ata Paniora and Another, Praying for Relief in Respect of Injustice Allegedly Suffered by Them in Relation to Waipoua 2B3B1 Block, Waipoua 2B3D2 Block, and Waipoua 2B3A Block" [1941] II AJHR G6A. 
evidence prevented the Court from forming any opinion. ${ }^{448}$ Another example was a petition from a European foster child seeking an exception to the legislative prohibition preventing her inheriting from her foster mother's will, which the Court declined to progress because removing the restriction would not benefit Māori. ${ }^{449}$

From 1948 a schedule of petitions was no longer included in Māori Purposes Acts, which likely reflected the decreasing number of petitions from the 1950s, with fewer petitions recommended for inquiry. ${ }^{450}$

\section{A Wakapuaka Block}

Three petitions presented to Parliament between 1933 and 1935 claimed rights in Wakapuaka Block in Nelson based on customary entitlements. These petitions were referred for inquiry by the Native Land Court via two pathways, and resulted in further legislative provisions in Māori Purposes Acts, including a further inquiry by the Court. This matter provides a good illustration of the inquiry process.

The claims dated back to the Native Land Court investigation of title in 1883 and the issue of a certificate of title to Huria Matenga as the sole owner of the block. On Huria Matenga's death the land passed by her will to her husband Hemi Matenga, who did not have an ancestral connection with the land. On his death, it passed to trustees.

The petition of Hari Wi Katene and others claimed that Wakapuaka had been gifted by Ngāti Kōata to Huria Matenga's grandmother Kauhoe, and other descendants of Kauhoe were entitled to the land in addition to Huria Matenga. The petition requested an inquiry. ${ }^{451}$ The petition of Waka Rawiri and Hoani Meihana claimed Ngati Tama had rights to Wakapuaka arising out of occupation and sought investigation by the Court into the rightful successors to the block. ${ }^{452}$ These petitions were considered by the Committee over several days and referred to the government for inquiry. ${ }^{453}$ Both petitions were included in the schedule of the Native Purposes Act 1934.

\footnotetext{
$448 \quad$ Native Land Court "Report and Recommendation on Petition No 39 of 1939, of Ngawharewiti Tiwai Pomare and Another, Praying for an Inquiry in Relation to the Estate of Wiremu Naera Pomare, Deceased", 17 April 1951 : National Archives, AAMK 869 W3074/751/b (24/1/5).

$449 \quad$ Native Land Court "Report and Recommendation on Petition No 75 of 1946, of Riri Piko, of Otewa, Praying that Statutory Provision may be made Authorizing and Directing the Native Land Court to make Succession Orders in Terms of the Will of Kura Raumoa, Deceased" [1947] III AJHR G6B.

$450 \quad$ This change is ascertainable in the annual reports of the Committee from 1950 until 1960.

451 Petition 262/1933: National Archives, AAMK 869 W3074/750/b (24/1/4).

452 Petition 123/1934: National Archives above n.

453 Native Affairs Committee "Reports of the Native Affairs Committee" [1934-35] III AJHR I3 at 7. See Native Affairs Committee Minute Book 1934-35: National Archives, AEBE 18507 LE1/1051 (1934/15).
} 
The third petition that formed part of the inquiry was presented to Parliament in 1935 by JA Elkington and others of Ngāti Kōata. The petition claimed the land had been gifted to Kauhoe for her son Wi Katene te Puoho, and because Wi Katene's line had died out the land reverted to Ngāti Kōata according to Native custom. This petition also sought an inquiry. ${ }^{454}$ The petition initially received no recommendation from the Committee, ${ }^{455}$ but this motion was rescinded and a new motion passed recommending the petition for favourable consideration by the government, with the suggestion the inquiry for the earlier petitions be extended to encompass this petition. ${ }^{456}$

Due to concerns the European trustees of Hemi Matenga's estate were not subject to the usual controls of the Court an initial legislative provision prohibited alienation of any land comprised in the Wakapuaka Block, except with the leave of the Court, until the report and recommendation of the Chief Judge had been considered by the Committee. ${ }^{457}$

The Native Land Court inquiry concluded "the evidence adduced to the Native Land Court of 1883 was insufficient to furnish that Court with the facts of the true history and ownership of the Whakapuaka Block". The Judge rejected the "official attitude" that had defeated repeated attempts by Māori to reopen the title but indicated some reservations about the Ngāti Kōata and Ngāti Tama claims in comparison with the claim of descendants of Kauhoe. ${ }^{458}$ The Chief Judge recommended all the petitioners be given the opportunity to place their claims "fully before the Court" and that legislation empower the Court to make orders as the justice of the case may require, without invalidating certain past transactions. ${ }^{459}$

The government supported the recommendation and a detailed legislative provision was enacted to progress the claims. The Native Appellate Court was given jurisdiction to reinvestigate the title and determine if the petitioners, or any persons claiming through them, had rights or interests according to the "ancient custom and usage of the Maoris in the said land either together with or in lieu of the estate of the said Hemi Matenga." The Court was empowered to determine the relative shares and interests of the petitioners or others found to be entitled to ownership of the land, and to vest any land in the estate of Hemi Matenga in such individuals as the Court considered just and equitable. The Court was also authorised to consider whether the petitioners should receive compensation in accordance with the rules

$454 \quad$ Petition 329/1934-35: National Archives, above n 451.

$455 \quad$ Native Affairs Committee Minute Book 1934-35, Meeting 27 February 1935: National Archives, above n 453.

$456 \quad$ Reports of Native Affairs Committee, above n 453, at 9.

457 Native Purposes Act 1935, s 12. See Native Purposes Bill 1935 (76-2) (select committee report), explanatory note, cl $11 \mathrm{~A}$.

458 Native Land Court "Report and Recommendation on Petition No 262 of 1933, of Hari Wi Katene and Others, Petition No 123 of 1934, of Waka Rawiri and Another, and Petition No 329 of 1934-35, of JA Elkington and Others Regarding Wakapuaka Block" [1936] II AJHR G6B at 57.

459

Above n, at 2. 
of equity, and if so, such payment could be ordered from assets held by the trustees of Hemi Matenga's estate. In making such a determination the Court was to take account of the expenses incurred by the petitioners in prosecuting their claims and to adjust any interests or compensation accordingly. The District Land Registrar was authorised to amend the register and issue fresh certificates of title as necessary. The Court was given discretion to permit the trustees to continue to manage any portion of the land that may vest in the petitioners. ${ }^{460}$

After decades of Crown inaction, and in the context of unfavourable observations about the obstructive behaviour of a prominent Crown official, this legislative provision gave the Native Appellate Court broad jurisdiction to resolve the petitioners' claims and it was a significant achievement. The bill was characterised as the "usual 'washing-up' Bill dealing with Native Affairs" which was not debated, meaning this important provision was not commented on in the House. ${ }^{461}$ As was the case with many "claims provisions" it passed through the House with only the scrutiny of the Committee.

Unfortunately, the Native Appellate Court's decision proved disappointing for Ngāti Kōata and Ngāti Tama, whose claims were rejected. ${ }^{462}$ These claims have been addressed within the modern Treaty of Waitangi settlements process, with the Crown acknowledging the failure of the legislative framework in preventing a large block of land from being vested in a sole owner and delays in securing reinvestigation of title. ${ }^{463}$

\section{B Petition of Ema Ruihi}

This petition was initially referred to government for favourable consideration by the Committee, ${ }^{464}$ but was placed in the Native Purposes Act 1941 schedule by the Department for inquiry by the Native Land Court. ${ }^{465}$ The recommendations of the Chief Judge to the Minister following inquiries usually adopted, or were similar to, the recommendations of the inquiry Judge. However, this was not always the case, which the petition of Ema Ruihi demonstrates. This example also illustrates further difficulties with succession and the legislative framework.

\footnotetext{
$460 \quad$ Native Purposes Act 1936, s 9.

$461 \quad$ (30 and 31 October 1936) 247 NZPD 1135 and 1152-1153.

462 For analysis of the decision and subsequent petitions see GA Phillipson "The Northern South Island: Part II" (Waitangi Tribunal, Rangahaua Whanui Series, October 1996) ch 2.

463 See Ngāti Kōata, Ngāti Rārua, Ngāti Tama ki Te Tau Ihu, and Te Ātiawa O Te Waka-a-Māui Claims Settlement Act 2014, ss 8-10 and 14-16. See Waitangi Tribunal Te Tau Ihu O Te Waka a Maui: Report on Northern South Island Claims, Volume II (Wai 785, 2008) at 733-768. Minutes of Native Affairs Committee, Meeting 20 August 1941: National Archives, AEBE 18507 LE1/1199 (1941/14).

$465 \quad$ Native Purposes Bill 1941 (No 33-1), Schedule, cl 1 and Native Purposes Act 1941, Schedule, cl 1.
} 
Ema Ruihi had been adopted in accordance with Māori custom and sought legislation allowing her to succeed to the estate of her adoptive father, which was prohibited under general legislative provisions. ${ }^{466}$

The inquiry Judge accepted the petitioner had been adopted in accordance with Māori custom, but rather than considering the equities of the matter, focused on the legal framework. The Judge concluded the customary adoption could have been registered for a period of time, enabling the petitioner to acquire succession rights. The unstated inference was the petitioner's parents had chosen not to do so. The Judge appeared skeptical of the petitioner's explanation her adoptive parents were illiterate and unaware of registration requirements. ${ }^{467}$

The Chief Judge advised the Minister the situation should not be decided solely on the legal status of the petitioner's adoption. The Chief Judge focused on aspects of the petitioner's evidence not referred to in the inquiry report, highlighting the petitioners' commitment to and care of her parents, which included financial support. Also influential was evidence her father had no other children and next-of-kin would be difficult to identify. In the absence of any objection to the petition, the Chief Judge thought denying the petitioner's claim would cause hardship and recommended Parliament allow the Native Land Court to deal with the petitioner's claim, which would provide further opportunity for any objection to be raised. The Committee recommended the Chief Judge's report to government for favourable consideration. ${ }^{468}$

The recommendation was supported and legislation authorised the Court to determine whether "in fairness" the whole or part of the estate should be awarded to Ema Ruihi. ${ }^{469}$ The Court was empowered to make orders in her favour if "right, just, reasonable and equitable" to do so, and for that purpose was not bound by Native custom. The provision was not discussed in the House. ${ }^{470}$ Although the inquiry and subsequent legislative provision did not finally determine the petitioner's claim, this was clearly due to concerns that any next-of-kin should have another opportunity to be heard.

Native Land Court "Report and Recommendation upon Petition No 71, of 1940, of Ema Hoera Ruihi, Concerning the Estate of Hoera Mei Maihi, Deceased", 16 August 1943, at 1: National Archives, AEBE 18507 LE1/1232 (1943/141).

467 Above n, at 2.

468 Native Affairs Committee "Reports of the Native Affairs Committee" [1943] II AJHR I3 at 7.

469 Native Purposes Act 1943, s 16. See Native Purposes Bill 1943 (29-2) (select committee report), explanatory note, cl 15A, and Minutes of the Native Affairs Committee, Meeting 25 August 1943: National Archives, AEBE 18507 LE1/1224 (1943/13).

$470 \quad$ Above $\mathrm{n} 243$. 


\section{Wellington Tenths Benefit Fund}

The petitions and legislative remedy in respect of the Wellington Tenths Benefit Fund provides an example of a statutory remedy that effectively resolved the problem brought before Parliament, in consultation with Māori petitioners.

Petitions presented to Parliament in 1947 sought the abolition of the Wellington Tenths Benefit Fund and dispersal of accumulated monies to beneficial owners. ${ }^{471}$ The fund was governed by section 36 of the Native Trustee Act 1930, which directed that up to $75 \%$ of the annual rents and proceeds of the lands were to be distributed by the Native Trustee to beneficiaries of the trust. The Trustee had the discretion to apply the remaining $25 \%$ to the "physical, social, moral, and pecuniary benefit" of the beneficiaries, with specific reference to relieving poverty or distress.

One petitioner argued the fund was no longer necessary due to a shift from communal living to individual living and with the introduction of social security benefits. This petitioner also argued that owners were not benefiting from the accumulated fund, with requests for assistance declined. An example was given of a New Plymouth hostel financed by the fund which was of no practical assistance to the owners themselves. ${ }^{472}$

In the subsequent inquiry, the Māori Land Court Judge acknowledged the benefit fund was useful for assisting Māori in need when it was first established, but agreed with petitioners the need for the fund had largely abated. However, the Judge was reluctant to recommend complete abolition of the fund. The Court reported the petitioners had agreed some funds should be retained in case of future need above and beyond government benefits, with distribution of the balance of accumulated funds to owners, and future distribution of all profits and rents to owners. The Court suggested an amount to set aside. ${ }^{473}$

The Chief Judge agreed with the inquiry report and recommended to the Minister that the fund be varied by legislative amendment to the Native Trustee Act $1930 .{ }^{474}$ This recommendation was given effect to by the Maori Purposes Act 1949. ${ }^{475}$ Assuming the petitioners were in agreement with the Court's

$471 \quad$ Petition 51/1947 (Taunatapu Rimene and 38 others) and petition 70/1947 (Ngaone Te Teira and others): See Maori Affairs Committee "Reports of the Maori Affairs Committee" [1947] IV AJHR I3 at 13. Petition 51/1947 is available at: National Archives, AEBE 18507 LE1/1299 (1947/16).

472 Letter of Taunatapu Rimene, 10 October 1947: National Archives, above n.

473 See Maori Purposes Act 1947, Schedule, cl 5 and Maori Land Court "Report and Recommendation on Petition No 51 of 1947, of Taunatapu Rimene and Others, and Petition No 70 of 1947, of Ngaone Te Teira and Others, Praying that the Wellington Tenths Benefit Fund be Abolished": National Archives, AEBE 18507 LE1/1335 (1948/306).

$474 \quad$ Above $\mathrm{n}$.

$475 \quad$ Maori Purposes Act 1949, s 32. 
recommendation as reported, this case serves as a straight-forward example of how Māori Purposes Acts could be used to respond practically to Māori needs and to allow for some element of Māori selfdetermination. This provision was briefly commented on, but not debated, in the House. ${ }^{476}$

\section{Conclusions}

Analysis of the petitions process indicates many more petitions failed than progressed to legislative provision within Māori Purposes Acts. This research confirms the process favoured discrete or individual problems compared with larger tribal claims or issues involving government policy, which is consistent with earlier literature. The greatest prospect of securing a swift legislative remedy flowed from a recommendation of the Committee for favourable consideration. In comparison, petitions requiring an inquiry could take much longer to progress.

Many petitions were generated by Crown mistakes. Even where there was no genuine factual dispute, the Crown was reluctant to fully acknowledge or accept responsibility for its errors, and in the case of Ngahuia Beasley, was willing to interfere with the legal and property rights of third parties to dispose of the problem at hand. Petitions were also generated by a legal system that did not fit Māori social needs, particularly in regard to succession and adoptions. Legislative provisions dealt with particular situations on an ad-hoc basis, but the general legislative framework and fundamental causes underlying petitions remained unaddressed. In the examples considered, there is little evidence that Treaty of Waitangi obligations featured in the claims and legislative responses.

The petitions process and subsequent legislative provisions fall within Llewellyn's law-job of resolving disputes and trouble-cases. However, the process by which some petitions were referred for inquiry by the Native/Māori Land Court on an equitable basis also reflects Llewellyn's third law-job of allocating authority for the disposition of trouble-cases. Legislative outcomes of the petitions were fact-specific and dependent on subjective assessments of equity and fairness by officials and Committee members. Consequently, the process and legislative remedies were unpredictable and could be inconsistent, which can be seen in the examples dealing with adoption. The process was not an adequate means for delivering justice, which is again consistent with earlier literature. ${ }^{477}$ Remedies that at face value appeared favourable for Māori, usually did not meet the criteria necessary for justice. Provisions did not restore Māori to their original position if issues such as costs and delay prior to the petition are considered. Because many provisions provided for another procedural step, outcomes and justice were actually

$476 \quad$ (25 November 1947) 279 NZPD 952-953.

477 Finny, above n 68, at 5, and Martin, above n 5, at 56. 
dependent on subsequent Court decisions. At best, legislative remedies took steps towards justice, and at worst, injustice could be perpetuated.

The fact the petitions process and consequent legislative remedies failed to deliver justice to Māori does not render the process without any merit or those provisions insignificant. Petitions were the only means of redress available to Māori, which is a poor indictment on New Zealand's legal system. Characterisation of legislative responses as "washing-up" or insignificant matters that did not require consideration or comment in the House was a convenient and misleading representation of the situation, reflecting a colonial mentality. This characterisation belies the complexity and historical nature of many claims, which was evident, and it ignored Māori struggle to achieve some form of remedy for valid claims. This characterisation also ignored the effect of many claims provisions that altered legal and property rights, significantly affecting the lives of those Māori involved. 


\section{Chapter 7: "Settlements" and Other Remedies}

\section{Overview}

This chapter examines remedial provisions in Māori Purposes Acts that addressed Māori grievances and claims against the Crown, some of which were expressed to be in full and final settlement or discharge of claims. These provisions often rectified mistakes made by the Crown, fulfilled outstanding obligations or recognised improper actions of the Crown, either by returning land or by providing some measure of compensation to Māori.

There was a close relationship between the petitions process and many of these remedial provisions. However, remedial provisions were infrequently the direct result of petitions as underlying claims often failed to progress until favourable Royal Commission recommendations were secured, or following a long period of further advocacy by Māori.

Literature considering early settlements between Māori and the Crown in the 1920s, 1940s and 1950s concluded that settlements were not entered into on the basis of Treaty of Waitangi obligations and compensation was limited. ${ }^{478}$ The Treaty of Waitangi was considered unenforceable in the Courts and Māori were prevented from proceeding against the Crown in respect of transactions relating to customary land. ${ }^{479}$ Other proceedings against the Crown were severely restricted until 1910 onwards. ${ }^{480}$ In this context, settlements were dealt with on the basis that Māori had no legal remedy for claims against the Crown, but it was recognised Māori had valid grievances and the Crown had a moral duty to address grievances based on concepts of "good conscience and equity". ${ }^{481}$

Provisions that attempted to resolve these disputes and claims fall squarely within Llewellyn's law-job of dealing with "trouble-cases". Many provisions empowered the Māori Land Court to determine entitlements to the land or compensation provided, which falls within Llewellyn's third law-job of allocating authority for the disposition of the claims or dispute. Consideration of settlements and remedial provisions within Llewellyn's framework focuses attention on the entirety of the situation, exposing the number of provisions and common themes, and the inability of New Zealand's legal system to deliver justice to Māori. In many cases, remedial provisions are located within the modern Treaty of Waitangi settlements process, which has dealt with grievances Māori Purposes Acts failed to permanently resolve.

\footnotetext{
$478 \quad$ Marr, above n 82.

$479 \quad$ Wi Parata v Bishop of Wellington, above n 59, at 18.

$480 \quad$ Above nn 61-62 and 64.
}

$481 \quad$ Above $\mathrm{n} 83$. 


\section{II $\quad$ Full and Final Settlements}

\section{A Royal Commission Recommendations}

Between the 1920s and early 1950s multiple Royal Commissions were established to investigate Māori claims and grievances. The Commissions' findings and recommendations for Crown action or compensation were given effect to with legislative provisions, usually years after recommendations were made. Legislation was used to achieve finality and terminate claims. Larger settlements were dealt with in specific settlement legislation, ${ }^{482}$ but Māori Purposes Acts were used to effect smaller settlements. Many settlements were inadequate and did not satisfy claimants' search for justice, which became evident in the modern settlement process.

Māori Purposes Acts were also used to adjust settlements implemented outside of the Acts, most particularly in the case of the Ngāi Tahu settlement. A Māori Purposes Act preserved an earlier provision preparing for settlement by establishing the Ngāi Tahu Trust Board, ${ }^{483}$ and later Māori Purposes Acts adjusted who qualified as beneficiaries of the settlement. ${ }^{484}$ A Māori Purposes Act was used in 1973 to extend the annual payment to Ngāi Tahu in perpetuity following a petition to Parliament the previous year. ${ }^{485}$ The Minister of Māori Affairs described extending the annual payments as "a realistic attempt to meet what has been a long outstanding problem and one that needs to be resolved in the interests of the people concerned and of the country generally". ${ }^{486}$ Māori Purposes Acts also adjusted the Whakatōhea and Waikato-Maniapoto confiscated lands settlements. ${ }^{487}$

\section{$1 \quad$ Jones Commission: Aorangi and Patutahi}

The Jones Commission of 1920, which dealt with various Māori petitions, resulted in settlements in Māori Purposes Acts many years later in respect of the Aorangi and Patutahi claims. The Aorangi claim is a good example of how Māori Purposes Acts were used to advance claims, demonstrating slow progress, with various legislative interventions along the way.

\footnotetext{
$482 \quad$ Ngai Tahu Claim Settlement Act 1944, Taranaki Maori Claims Settlement Act 1944 and Waikato-Maniapoto Maori Claims Settlement Act 1946. Native Purposes Act 1931, s 65, consolidating Native Land Amendment and Native Land Claims Adjustment Act 1928, s 21.

$484 \quad$ Maori Purposes Act 1948, ss 4 and 5, Maori Purposes Act 1966, s 16 and Maori Purposes Act 1975 , s 13.

485 Maori Purposes Act 1973, s 3. See (14 September 1972) 380 NZPD 2552-2558.

$486 \quad$ (8 June 1973) 383 NZPD 1197.

487 Maori Purposes Act 1949, s 26 (Whakatōhea). For Waikato-Maniapoto, see Maori Purposes Act 1968 , s 12 and Maori Purposes Act 1978, s 5.
} 
The Jones Commission found the Aorangi block was lost to Māori due to a series of mistakes made by officials of the Crown and provincial authorities in the 1850s and 1860s, who assumed the land had passed to the Crown under deeds of sale. The northern part of the land was mistakenly believed to be included in a deed of sale, and although the southern portion of the land was included in a deed of sale, the Commission considered the sale was not made with the consent of all Māori interested in the land. ${ }^{488}$

The Commission did not specify a remedy, which prompted legislative authorisation of a Native Land Court inquiry to ascertain what compensation should be paid. ${ }^{489}$ The inquiry recommended compensation that was much lower than Māori wanted, but provision was made for interest and some costs, arriving at a compensatory figure of $£ 38,545.490$ The Native Purposes Act 1931 confirmed the recommended compensation, or a modified amount, could be effected subject to appropriation by Parliament. ${ }^{491}$ The Native Purposes Act 1935 authorised the Governor-General to establish another Commission to inquire into compensation in respect of the Aorangi claim, although this was never acted on. ${ }^{492}$ Over the years that followed there was no dispute about the validity of the claim, with express recognition the claim was well founded. ${ }^{493}$ The barrier to resolution was quantum.

At a conference with the Native Minister and officials in 1938 Māori sought compensation of $£ 68,000$ and reminded the Crown of its obligations as protectors of Māori rights. The Minister promised to raise the claim with his colleagues but attempted to lower Māori expectations, reminding representatives that there were many expensive Māori claims before the government. ${ }^{494}$ In the case of the Patutahi claim also discussed, the Minister took a similar approach, pointing out there was social legislation in place that would benefit Māori, and the difficulty of asking the Pākehā majority to fund compensation. ${ }^{495}$

The Crown did not progress settlement for many years. Finally, in 1949 further discussion about the Aorangi claim took place and Māori sought additional compensation given the further delay. ${ }^{496}$

Native Land Claims Commission "Reports of the Native Land Claims Commission" [1921-22] II AJHR G5 at 6-11. Native Land Amendment and Native Land Claims Adjustment Act 1928, s 47, which also provided for the Patutahi claim.

Report of the Chief Judge, 30 April 1929: National Archives, ACIH 16036 MAW2459/31 (5/13/52).

Native Purposes Act 1931, s 108.

Native Purposes Act 1935, s 21. The Patutahi claim was also addressed in this provision.

See for example Memorandum to Minister of Maori Affairs, 14 December 1948: National Archives, above n 490. See also Cabinet Paper (50) 602, 5 July 1950 and attached Memoranda from Minister of Maori Affairs: AAFD 811 W2347/114/k (CAB266/2/1).

See notes of the "Conference of Representatives of the Maori People with the Hon Acting Native Minister and Government Officials concerning Confiscated Land and other Outstanding Claims of the Maoris”, 22 February 1938: National Archives, above n 490.

Above n.

Notes of Representations made to Minister of Maori Affairs, 20 June 1949: National Archives, above n 490. 
Ultimately Māori accepted £50,000 in compensation, which fell short of what Māori wanted, but was more than the government wanted to pay. ${ }^{497}$ The Maori Purposes Act 1950 provided for payment of that sum to the Māori Trustee "in settlement of all claims and demands" in respect of the block. The provision directed that, after payment of costs, half of the money was to be paid to entitled owners and the balance was to be paid to trustees appointed by the Governor-General on the recommendation of the Minister. This balance was to be held for descendants of beneficial owners on trusts declared by the GovernorGeneral. The Māori Land Court was to ascertain who entitled owners were. Beneficial owners were able to nominate trustees following a majority vote, although the Minister was not bound by such nominations. ${ }^{498}$ The provision anticipated that costs would be agreed by the owners, but difficulties necessitated further provision in Māori Purposes Acts authorising the Māori Land Court to determine who should receive costs, ${ }^{499}$ and subsequently, allowing the Māori Trustee to distribute the unallocated balance. $^{500}$

It is clear that with no alternate options available, Māori compromised their claim for a sum of money they considered inadequate given the Crown's prevarication in respect of a grievance accepted as valid for many years. Unsurprisingly the grievance persisted into the modern Treaty of Waitangi process with various acknowledgements of the Crown's failings. ${ }^{501}$

The Patutahi claim followed a similar pathway as the Aorangi claim, and also involved a claim the Crown had taken land in error. ${ }^{502}$ The Commission did not find sufficient evidence to support the full claim, but concluded Rongowhakaata had been deprived of over 20,000 acres of land due to a mistake made by the Poverty Bay Commission of 1869.503 The Maori Purposes Act 1950 provided for payment of compensation to the Māori Trustee for distribution on a specified basis, ${ }^{504}$ the majority of the compensation being interest for delayed settlement. ${ }^{505}$ The provision authorised the Māori Land Court to ascertain entitlements to the compensation, and a previous Court order was cancelled. Again, it was

\footnotetext{
497 Memorandum for Minister of Maori Affairs, 14 December 1948, National Archives, above n 490.

$498 \quad$ Maori Purposes Act 1950, s 62.

$499 \quad$ Maori Purposes Act 1953, s 24.

$500 \quad$ Maori Purposes Act 1956, s 8.

501 Heretaunga Tamatea, Trustees of the Heretaunga Tamatea Settlement Trust, and the Crown, Deed of Settlement of Historical Claims, 26 September 2015, at 19, 45 and 92.

$502 \quad$ See Native Purposes Act 1931, ss 93 and 94, and above nn 492 and 494.

503 Above $\mathrm{n}$ 488, at 14-20. For the history of the Patutahi Block claim see Rongowhakaata Including Nga Uri O Te Kooti Rikirangi, The Trustees of the Rongowhakaata Settlement Trust and the Crown, Deed of Settlement of Historical Claims, 30 September 2011, at 18-19.

$504 \quad$ Maori Purposes Act 1950, s 58.

505 See Cabinet Paper (50) 997 and Memorandum, Acting Secretary to Treasury, 10 July 1950: National Archives, above n 493.
} 
clear that with no alternate option, Māori accepted less compensation than they wanted. ${ }^{506}$ This grievance also persisted into the modern Treaty of Waitangi settlements process, with express acknowledgement a breach of the Treaty of Waitangi had occurred in respect of the "effective confiscation". 507

There was limited discussion of these claims in the House when the settlement provisions were before it as they were not in parts of the Bill recognised as significant and the Committee had not amended the Bill. The tenor of the limited discussion was congratulatory of the government because it had resolved the claims, despite delays, which the Member for Southern Māori considered Māori were responsible for. ${ }^{508}$

\section{$2 \quad$ Pukeroa-Oruawhata claim}

Settlement of the Pukeroa-Oruawhata or Rotorua township claim in the Maori Purposes Act 1954 following recommendations of a Royal Commission in 1948 demonstrates the difficulties Māori faced in arguing their claim on a legal basis, necessitating reliance on subjective concepts of fairness and moral obligation. This example provides another illustration of how Māori Purposes Acts were used to progress the claim.

At the instigation of the Crown, Māori entered into an agreement, known as the Fenton Agreement, permitting the Crown to survey and lay out Rotorua township and to enter into leases as the agent of Māori. ${ }^{509}$ Following development of the town, leases were successfully auctioned for much higher prices than anticipated. However, in the context of a depression the scheme failed and lessees failed to pay their rents. ${ }^{510}$ The situation was acknowledged as "unsatisfactory... and extremely unprofitable to the Natives", and in an attempt to resolve the situation, the Crown purchased the land from Māori. ${ }^{511}$ An attempt by Māori to bring legal proceedings against the Crown for its management of the township failed

506

See Memorandum of Minister of Maori Affairs, undated, accompanying Cabinet Paper (50) 997: National Archives, above $\mathrm{n} 493$.

507 Deed of Settlement, above n 503, at 18-19 and 61.

508

509

510

511
(29 November 1950) 293 NZPD 4722-4731 and 4679.

See RP Boast "Treaties Nobody Counted On” (2011) 42 VUWLR 653 at 660-662; Boast, Buying the Land, above n 53, at 169-173.

See Boast Buying the Land, above n, and Royal Commission "Report of Royal Commission Appointed to Inquire Into and Report upon Claims Preferred by Certain Maori Claimants concerning the Pukeroa-Oruawhata (Rotorua Township) Block" [1948] III AJHR G7 at 16.

Native Land Court "Report and Recommendation on Petition No 55 of 1928, of Pirika Te Miroi and Others, and Petition No 146 of 1934, of Wiremu Keepa Patahuri and Others, Praying for Relief in Respect of the Administration and Acquisition of the Pukeroa-Oruawhata Block (Town of Rotorua) by the Crown" [1936] II AJHR G6D at 6-7 and Commission Report, above n, at 12. 
because the limitation period had passed. ${ }^{512}$ Petitions were presented to Parliament, two of which were referred for inquiry by the Native Purposes Act $1934,{ }^{513}$ resulting in a report from the Chief Judge in 1936.

The 1936 inquiry focused on the Crown's administration of the leasing arrangements, and the circumstances of the Crown's purchase of the block. Chief Judge Jones, who conducted the inquiry, recommended the Crown make an ex gratia payment to Māori. Although allowance was made for the difficulty of collecting rent in the depression, the Judge considered the Crown had not acted properly in allowing lessees to forfeit leases without attempting to collect rents, noting the fiduciary relationship found by the Supreme Court to exist in relation to the leasing arrangement. ${ }^{514}$ The Chief Judge was conservative in calculating compensation in respect of the leasing, basing it on annual rental that should have been collected pursuant to forfeited leases for an arbitrary period of five years, with a discount for bad debts. In respect of the subsequent Crown purchase of the township, the Judge questioned the basis upon which the purchase price had been calculated but did not pursue an argument about the legality of the sale because transactions had been validated and no objection had been raised to the sale itself. ${ }^{515}$

Following the report, Māori lobbied for better compensation than had been recommended, ${ }^{516}$ but nothing was done to progress the claim. This was partly because Ministers and officials considered the claim lacked merit. ${ }^{517}$

Further petitions in 1945 sought referral of the claim to a Royal Commission. ${ }^{518}$ A Royal Commission was established to consider whether Māori should "in fairness" receive compensation for the acts or omissions of Crown officials in respect of the administration of the township, and whether the purchase price was fair and reasonable. ${ }^{519}$ Māori argued the fiduciary relationship prevented the Crown from purchasing the block, but the Commission confined that relationship to the leasing arrangements and rejected the argument the Crown was prevented from buying the township. The Commission concluded

\footnotetext{
512 Court Report, above n 511, at 5-6. The Commission questioned this scenario: Commission report, above n 510, at 9-10.

$513 \quad$ Native Purposes Act 1934, Schedule, cl 2.

$514 \quad$ Court report, above $\mathrm{n} 511$, at 5-6.

515 Court report, above $\mathrm{n} 511$, at 6-8.

516 Conference notes, above n 494, at 26-42: available also at National Archives, AAMK 869 W3074/205/b (7/6/66).

517 For example, see Letter, Native Minister to Ngati Whakaue Township Committee, 12 May 1947 and Memorandum of Crown Solicitor, 21 September 1936: National Archives, above $\mathrm{n}$.

518 Petitions 96/1945 and 107/1945: see Maori Affairs Committee "Reports of the Maori Affairs Committee" [1945] II AJHR I3 at 13 and 15.

519 Commission report, above n 510, at 3.
} 
the adequacy of the purchase price was the key issue ${ }^{520}$ The Commission was unwilling to accept bad faith by Crown officials, but indicated the Crown should be accountable for errors of judgment. ${ }^{521}$ The Commission concluded that "in fairness" Ngāti Whakaue was entitled to some compensation based on similar reasoning to the Chief Judge, but the Commission recommended a greater sum of compensation to cover both the leasing and purchase of the township, an amount reached "in a spirit of compromise". ${ }^{522}$

Ngāti Whakaue were unhappy with the recommended compensation and lobbied for several years for more, ${ }^{523}$ with dissension within the tribe over the amount of compensation complicating the situation. ${ }^{524}$ The government was unwilling to pay more than the Commission had recommended, and when Ngāti Whakaue persisted with their claim, the government adopted an incongruously legal approach by treating its willingness to pay compensation recommended by the Commission as an offer that had lapsed. Once it was clear the government would not negotiate, Ngāti Whakaue was compelled to apply for payment of the compensation recommended by the Commission. ${ }^{525}$

The Maori Purposes Act 1954 effected payment of the recommended compensation to the Māori Trustee in "settlement of all claims and demands arising out of the management, administration, and control by the Crown of the block". ${ }^{526}$ The provision directed allocation of the funds towards costs, with the balance to be distributed between the beneficial owners of certain land. The legislation was described in the House as containing "washing up" matters, with settlement of the Rotorua township claim the "main purpose" of the bill. ${ }^{527}$ The government was defensive about any suggestion it was responsible for delays in settling the claim, explaining the government "could not get the people ... to accept settlement in accordance with the findings of the Commission" and "the delay is solely attributable to the people themselves" ${ }^{528}$ The possibility that compensation was inadequate, the process unfair, or that an injustice was being perpetuated was not contemplated.

\footnotetext{
520 Commission report, above n 510, at 10-12.

$521 \quad$ Commission report, above n 510, at 13.

522 Commission report, above n 510, at 20.

$523 \quad$ Notes, "Representations made to Minister of Maori Affairs (Rt. Hon P Fraser) and Hon ET Tirikatene, Parliament Buildings, Wellington, Thursday 18 August 1949" and Notes of Interview, 25 October 1950: National Archives, AAMK 869 W3074/206/b (7/6/66).

524

526

527

528 Letter, Cooney to Minister of Maori Affairs, 19 December 1951: National Archives, AAMK 869 W3074/206/c (7/6/66).

25 See various correspondence and documentation and Cabinet Paper CP (54) 6, 18 January 1954: National Archives, above $n$. Maori Purposes Act 1954, s 4. (16 September 1954) 304 NZPD 1765. (27 September 1954) 304 NZPD 1964-1969.
} 
Ngāti Whakaue subsequently filed a claim with the Waitangi Tribunal, which included the Crown's failure to fulfill its responsibilities as Ngāti Whakaue's agent in relation to the Rotorua township leasing scheme. A settlement agreement was entered into with the Crown in 1993, in which the Crown agreed review of previous compensation was justified. Ngāti Whakaue received valuable lands and a payment towards their costs in settlement of claims relating to the leasing of Rotorua Township, PukeroaOruawhata block and pursuant to the Fenton Agreement, along with other matters. ${ }^{529}$ However, the issue of compensation for the Pukeroa-Oruawhata block remains problematic, with a further claim before the Waitangi Tribunal. ${ }^{530}$

\section{$3 \quad$ Sim Commission and surplus lands}

The findings and recommendations of other Royal Commissions also resulted in settlement provisions within Māori Purposes Acts, including recommendations of the Sim Commission relating to confiscated lands claims, ${ }^{531}$ and those of the Surplus Lands Commission. ${ }^{532}$ It is beyond the scope of this thesis to consider these complex issues, which have been the subject of detailed examination within the modern Treaty of Waitangi process. ${ }^{533}$ Consideration of how Māori Purposes Acts were used to address tribal claims to Tarawera-Tataraakina blocks in the Hawkes Bay is also beyond the limits of this research. These claims involved multiple petitions, several Native Land Court inquiries and multiple legislative interventions cancelling Court orders and changing Māori interests in the land before the Maori Purposes Act 1952 implemented Royal Commission recommendations, reversing earlier legislative provisions and providing for compensation to some owners. ${ }^{534}$

\footnotetext{
529 Agreement between the Minister of Justice on Behalf of the Crown, and Pukeroa-Oruawhata Trustees and the Proprietors of Ngati Whakaue Tribal Lands Inc, for and on Behalf of the People of Ngati Whakaue, in Relation to Claim Wai 94: <https://www.govt.nz/treaty-settlement-documents/ngati-whakaue/>.

530 See Te Komiti Nui O Whakaue Reference Document for Presentation at the Registered Voting Hui on 4 September 201: <http://www.whakaue.org/wp-content/uploads/2016/09/BROCHURE-BLACK-OUTS.pdf> and <www.whakaue.org/settlements>.

531 Maori Purposes Act 1949, s 29. See Royal Commission "Report of Royal Commission to Inquire into Confiscations of Native Lands and other Grievances Alleged by Natives" [1928] II AJHR G7 at 24-27. The view of the dissenting member is set out at 36-40.

$532 \quad$ Maori Purposes Act 1953, s 28. See Royal Commission, above n 196.

533 For example, see Waitangi Tribunal Muriwhenua Land Report (Wai 45, 1997). See also Ngāti Whātua o Kaipara and the Crown, Deed of Settlement of Historical Claims, 9 September 2011, at 43.

534 Maori Purposes Act 1952, s 13. For petitions referred for inquiry in 1936 see Native Purposes Act 1937, Schedule, cls 3, 7 and 8 and Native Land Court "Report and Recommendation on Petition No 66 of 1936, of W Baker and Others, Petition No 262 of 1936, of Kaperiera Te Pohe and Others, and Petition No 301 of 1936, of Matewai Utiera and Others, Re Tarawera Block" [1939] II AJHR G6A. For a full history, see Waitangi Tribunal Te Mohaka Ki Ahuriri Report (Wai 201, 2004) at 328-358. See also Deed of Settlement, below n 589, at 27-28.
} 


\section{B Other Settlements}

Māori Purposes Acts also contained another category of settlement provisions deriving from errors of Crown officials, but which did not follow from the findings or recommendations of Royal Commissions. The remedial provisions in this category usually found their way into Māori Purposes Acts after belated discovery of an error that had to be rectified, because Māori had advocated for a remedy, or a combination of the two factors. A more unusual example was a provision facilitating the release of monies managed by the Crown, which was expressed as a settlement. ${ }^{535}$

\section{$1 \quad$ Wairahi}

A key example was the settlement of a grievance relating to an area of land known as Wairahi in the Far North. I have chosen this example because it differs from the remedial provisions considered so far because land was returned to Māori. ${ }^{536}$ The fact this claim was addressed by a Māori Purposes Act was largely due to the persistence of Māori and the willingness of local Native Land Court Judge, Judge Acheson, to advocate on their behalf.

The history of this claim has been well-documented before the Waitangi Tribunal. ${ }^{537}$ The claim involved the wrongful inclusion of a portion of Parengarenga Block, known as Wairahi, within the boundaries of Muriwhenua South Block, as a result of survey errors. The first survey error was made in 1857 when a surveyor confused two place names on the northern boundary, with the effect the Crown received 2800 acres more than it should have under the deed of purchase. The error was not discovered until many years later. Officials accepted an error had occurred. A further survey was completed and that area of land was returned to Te Aupōuri in 1896. However, Māori remained unhappy with the new boundary line and Judge Acheson raised their complaint with the Department in the late $1920 \mathrm{~s} .{ }^{538}$ This claim was initially questioned, ${ }^{539}$ but the Chief Surveyor concluded the claim should be admitted. ${ }^{540}$ In late $1920 \mathrm{~s}$ the focus was on how the claim should be resolved and whether any land in the area was available for

\footnotetext{
$535 \quad$ Maori Purposes Act 1954, s 7.

$536 \quad$ Native Purposes Act 1938, s 18.

537 See Muriwhenua Land Report, above n 533, at 349-350, RP Boast "The Muriwhenua South and Ahipara Purchases: A Report to the Waitangi Tribunal" (Wai 45, March 1992) at 16-28, and Claudia Geiringer "Muriwhenua Land Claim, Subsequent Maori protest arising from the Crown Land Purchases in Muriwhenua 1850-1865" (Wai 45, April 1993) at 41-51.

538 Letter, Acheson to Under-Secretary, 16 May 1927, and Memorandum, 14 February 1928: National Archives, ABWN 6095 W5021/248 (7/685).

539 Memorandum, Commissioner Crown Lands to Under-Secretary for Lands, 23 April 1928: National Archives, above n.

$540 \quad$ Memorandum of Chief Surveyor, 9 August 1928: National Archives, above n 538.
} 
settlement. ${ }^{541}$ Compensation was also considered, but the claim stalled when agreement could not be reached about the extent of the loss. ${ }^{542}$ Judge Acheson took the matter up again in $1931,{ }^{543}$ and although the Department of Lands and Survey now denied any mistake had occurred, ${ }^{544}$ it was suggested the Native Land Court conduct a full investigation. ${ }^{545}$

The investigation was effected under section 542 of the Native Land Act 1931. Judge MacCormick's findings have been described as "confusing"546 and "less than successful in resolving the Wairahi issue". 547 The findings are difficult to follow and open to interpretation. ${ }^{548}$ The Judge considered there was insufficient evidence to support the argument made by Māori that part of the northern boundary should have followed Wairahi stream, but taking account of the adjustment made in 1896, the Judge was not satisfied the amended boundary line matched the deed or plan either. The Judge adopted a new boundary line, which effectively recognised Māori had lost about half of the area claimed. ${ }^{549}$ The Judge recommended Māori "be given an area of Crown land equal in value" to the land lost, plus "some reasonable compensation". 550 The Court's approach could be viewed as a pragmatic response to the difficulty of reconciling the deed and various survey plans with the evidence, perhaps with an undefined sense that Māori were entitled to some remedy.

The subsequent negotiation process was fraught, with Judge Acheson suggesting the whole process was contrary to the spirit of the Treaty of Waitangi. ${ }^{551}$ Māori were displeased with the quality of the replacement lands offered by the Crown, prompting a request for additional lands. ${ }^{552}$ In response to Crown resistance, ${ }^{553}$ Judge Acheson lobbied for additional lands to be provided under a consolidation scheme if not as part of the settlement, pointing out the long delay was causing Māori real hardship. ${ }^{554}$

\footnotetext{
541 Memorandum, Commissioner of Crown Lands to Under-Secretary for Lands, 5 March 1929: National Archives, above n 538 .

$542 \quad$ See correspondence from 5 March 1929 to 21 May 1930: National Archives, above n 538.

543 Memorandum, Acheson to Under-Secretary, 3 August 1931: National Archives, above n 538.

544 Memorandum of Surveyor-General, 14 August 1931: National Archives, above n 538.

545 Memorandum, EA Ransom to Native Minister, 5 June 1933: National Archives, above n 538.

$546 \quad$ Geiringer, above $\mathrm{n} 537$, at 47.

$547 \quad$ Boast, above n 537, at 24.

$548 \quad$ Report of Judge McCormick, Muriwhenua South Block, 27 October 1933: National Archives, above n 538.

$549 \quad$ Boast, above $\mathrm{n}$ 537, at 23-24.

$550 \quad$ Above $\mathrm{n}$ 548, at 10 .

$551 \quad$ Letter, Acheson to Under-Secretary, 9 March 1935: National Archives, above n 538.

552 Letter, Registrar to Under-Secretary of Lands, 31 January 1936, and Memorandum, Commissioner of Crown Lands, 31 May 1935: National Archives, above n 538.

553 Memorandum, Commissioner of Crown Lands and Chief Surveyor to Surveyor-General, 17 March 1936: National Archives, above n 538.

$554 \quad$ Memoranda of Court Registrar, 30 May and 17 June 1936: National Archives, above n 538.
} 
The Commissioner of Lands wanted to deal with the additional land area separately to the settlement, ${ }^{555}$ and Māori accepted the Crown's proposal of 865 acres in settlement of the Wairahi claim, with the expectation additional lands would be received under the consolidation scheme. ${ }^{556}$

Special legislation was considered necessary to provide authority for the settlement. ${ }^{557}$ The Native Purposes Act 1938 deemed the 865 acres to be Crown land set aside for the owners of Parengarenga Block and their descendants "in full satisfaction and discharge" of claims relating to the block. The Native Land Court was authorised to ascertain who should be included in the certificate of title and to determine relative interests under the Native Land Act 1931. ${ }^{558}$ Delays occurred after it proved impractical to issue title to the several hundred people who would be entitled. A request to vest the land in the tribe was denied, but it was agreed it could be vested in trustees. ${ }^{559}$ There was no debate about this settlement in the House. The Bill was characterised as "a short 'washing-up' Bill” and received limited consideration. ${ }^{560}$

The loss of land at Wairahi was addressed in the modern treaty of Waitangi settlement process. ${ }^{561}$ The Crown acknowledged the northern boundary of Muriwhenua South Block was not properly defined, which caused problems, and that its failure to fully investigate and rectify the situation at Wairahi for so many years was a breach of the Treaty of Waitangi. ${ }^{562}$ The settlement also acknowledged Te Aupōuri had expected additional land subsequent to the settlement in the Native Purposes Act 1938, which never eventuated. ${ }^{563}$

\section{Ohinemuri and Omarunui}

Further examples of remedial provisions can be found in the Māori Purposes Acts of 1946 and 1953.

\footnotetext{
555 Memorandum of Commissioner of Crown Lands, 28 October 1937: National Archives, above n 538.

556 Letter, Acheson to Native Department, 1 August 1938: National Archives, above n 538. For subsequent events see Boast, above n 537, at 25-26.

$557 \quad$ See correspondence in August 1938: National Archives, above n 538.

$558 \quad$ Above n 536.

559 Memorandum to Under-Secretary of Lands, 22 September 1942 and Letter, Chief Surveyor to Under-Secretary for Lands, 23 March 1945: National Archives, above n 538.

$560 \quad$ (15 September 1938) 253 NZPD 482 and 485.

561 Te Aupōuri and the Crown, Deed of Settlement of Historical Claims, 28 January 2012, at 21-22. The Maori Purposes Act 1953 established the Aupouri Trust Board to administer land, including the 865 acres provided under the 1938 Act: Maori Purposes Act 1953, s 21.

562 Deed, above $n$, at 41-42.

563 Deed, above $n$ 561, at 33
} 
The Native Purposes Act 1946 addressed the problem of 500 acres of land at Ohinemuri, near Waihi, which had been treated as Crown land since 1879 without any record of conveyance of title to the Crown. This problem was discovered when registration of land dealings was attempted many years later. ${ }^{564}$ The legislation vested the land in the Crown and directed payment of specified compensation to WaikatoManiapoto District Maori Land Board to be held on trust for the former owners of the land in "good and effectual discharge" of any claim against the Crown. ${ }^{565}$ The option of returning the land to Māori was ruled out due to the rights of third parties. ${ }^{566}$ There was no debate in the House about any of the provisions of this Act on the basis they had been considered by the Committee and explanatory notes were available. ${ }^{567}$

The Maori Purposes Act 1953 settled a "longstanding claim" in respect of 163 acres of land at Omarunui in the Hawkes Bay, which had been "erroneously included in a Crown grant" issued in $1866 .{ }^{568}$ The legislation directed payment of specified compensation to the Māori Trustee for distribution to those who would have been owners of the land in accordance with Māori custom and usage. The Māori Land Court was empowered to determine those entitlements. ${ }^{569}$ This remedial provision followed a petition by Māori, who had repeatedly attempted to secure the return of the land. ${ }^{570}$ The contents of the 1953 Bill were characterised as being of the "usual washing-up" nature, and there was no mention of this provision in the House. ${ }^{571}$

\section{$3 \quad$ Awhitu}

The last settlement provision contained in Māori Purposes Acts falls within this category of remedial provisions, but was negotiated in a different political climate to the earlier provisions considered.

The claim relating to Awhitu Parish arose from a litany of Crown errors, the last in the chain being in 1950 when a second certificate of title was issued for substantially the same parcel of land. The errors were discovered in 1964 when an investigation into the title took place. ${ }^{572}$ Māori wanted title to the land as provided by an 1857 agreement with the Crown, but matters were complicated by the interests of an

\footnotetext{
$564 \quad$ Native Purposes Bill 1946 (60-1) (explanatory note), cl 14.

$565 \quad$ Native Purposes Act 1946, s 14.

566 Above $\mathrm{n} 564$.

$567 \quad$ (10 and 11 October 1946) 275 NZPD 673 and 689.

$568 \quad$ Maori Purposes Bill 1953 (143-1) (explanatory note), cl 24.

569 Maori Purposes Act 1953, s 25.

570 Ahuriri Hapū and the Trustees of the Mana Ahuriri Trust and the Crown, Deed of Settlement of Historical Claims, 2 November 2016, at 29-30.

$571 \quad$ (26 November 1953) 301 NZPD 2504-2507.

572 Report of Phillips, 28 October 1977: National Archives, ABWN 6095 W5021/690 (23/1099/1).
} 
adjacent farmer who was occupying the land without title. ${ }^{573}$ The view of officials in the 1970s was the Crown owed no legal obligation to Māori because the limitation period had expired but owed a moral obligation to fulfil the Crown's original intention Māori receive the land. ${ }^{574}$ The Minister of Māori Affairs was later advised protections for Māori in the Treaty of Waitangi were relevant to the Crown's obligations to resolve the problem. ${ }^{575}$ The Commissioner of Crown Lands and Minister of Lands were unconvinced, considering the matter a dispute between citizens, and that litigation brought by the farmer should run its course before the Crown intervened. ${ }^{576}$

An agreed settlement between the Crown, Māori and adjacent farmer was finally progressed following Māori protest and occupation of the land. ${ }^{577}$ The Crown bought the farmer's land, securing the land for Māori. ${ }^{578}$ Legislative provision was necessary to cancel certificates of title, declare the land to be Māori freehold land to which certain descendants were entitled, and establishing the legal right of descendants of another party to bring an action against the Crown if necessary. ${ }^{579}$

Characterisation of the legislation in the House was contradictory, reflecting the contradiction between a generic "washing-up" characterisation and significant provisions. Although the Bill was described by the Minister of Māori Affairs as being a "washing-up" bill and non-contentious, the Awhitu settlement was acknowledged as "major" and the situation it remedied was described as "an extraordinary chapter of errors". ${ }^{580}$ The Member for Southern Māori viewed the situation as less extraordinary, and reflective of many other injustices experienced by Māori, which necessitated more resources to determine such claims. ${ }^{581}$ There was no disagreement in the House about resolving the claim, and the volume of future land claims under the extended jurisdiction of the Waitangi Tribunal was forecast. ${ }^{582}$

Maori Purposes Bill 1984 (55-1) (explanatory note), cl 2.

See above n 572, and Memorandum of Office Solicitor, 15 November 1977: National Archives, above n 572. Memorandum to Minister of Maori Affairs, 20 May 1980 at 5-6: National Archives, above n 572. Memorandum of Commissioner of Crown Lands, 19 June 1980 and Letter of Minister of Lands, 29 September 1980 : National Archives, above n 572.

“Maori Land Protest Flag Raised Again” Waikato Times (Waikato, 5 November 1980): National Archives, above n 572.

578 Maori Purposes Bill 1984 (55-1) (explanatory note), cl 2 and Maori Purposes Act 1984, s 2 preamble.

$579 \quad$ Maori Purposes Act 1985, s 2.

$580 \quad$ (7 December 1984) 460 NZPD 2467.

$581 \quad$ Above $\mathrm{n}$, at 2469-2470.

$582 \quad$ (19 July 1985) 464 NZPD 5778-5781.
} 


\section{Other Remedies}

In addition to remedial provisions expressed to be in full and final settlement, there were a number of provisions in Māori Purposes Acts that returned land or recognised a wrong had occurred and provided mechanisms for compensation to be determined, without being expressed as settlements. While I focus on provisions that are similar to settlements, it is important to recognise the legislation also contained provisions dealing with claims or problems such as preserving rights under leases of Māori land while issues of compensation for improvements was considered ${ }^{583}$ or providing for procedural steps in claims not subsequently resolved within the legislation. ${ }^{584}$

\section{A Return of Land}

Provisions returning land to Māori ownership usually related to the return of school sites that were no longer required by the Crown. In the absence of general legislative authority, provisions effected return of the land, ensuring it ceased to be Crown land or subject to any Crown claim, and conferred Native land status. Provisions also empowered the Native Land Court to determine entitlements to the land and make vesting orders. ${ }^{585}$

\section{$1 \quad \bar{O}$ whāoko gift blocks}

The return of the Ōwhāoko gift blocks provides a more unusual example of the return of land, demonstrating belated Crown acknowledgement of a fundamental legal principle and the difficulties that could arise subsequent to the remedial provision, which the Māori Land Court had to resolve.

The land was gifted to the Crown by Ngāti Tūwharetoa for the settlement of discharged Māori soldiers, a gift that was commended at the time. ${ }^{586}$ However, doubts about the suitability of the land for settlement

\footnotetext{
583 Maori Purposes Act 1948, s 13 as amended by Maori Purposes Act 1950, s 8, Maori Purposes Act 1951, s 9, Maori Purposes Act 1952, s 6 and Maori Purposes Act 1953, s 29.

584 For jurisdiction allocated in respect of the Wanganui River claim, see Maori Purposes Act 1951, s 36, extended by the Maori Purposes Act 1954, s 6. See also Native Purposes Act 1931, s 100 and Native Purposes Act 1935, s 21 (Waipuku-Patea Reserve).

585 Native Purposes Act 1931, s 75, Native Purposes Act 1933, ss 10 and 11, Native Purposes Act 1936, s 7 and Native Purposes Act 1941, s 8.

586 See "Provision for Maori Soldiers" Taihape Daily Times (Taihape, 9 October 1916): National Archives, AAMX 6095 W3430/6 (26/1/12). The gift was authorised by the Native Land Amendment and Native Land Claims Adjustment Act 1917, s 4.
} 
quickly formed. ${ }^{587}$ Those doubts culminated in legislation releasing the land from any trust to settle the land on discharged Māori soldiers, subject to revenues from the land being applied to the "assistance" of discharged Māori soldiers, an obligation that could only be amended by the Native Land Court. ${ }^{588}$ This provision was enacted without consultation with Māori. ${ }^{589}$ Further legislative provision was made the following year to deal with leases over the land that had not been dealt with. Legislation validated rental payments made to Māori owners and allowed them to continue to receive full rental without deduction regardless of the gift. ${ }^{590}$ This arrangement was motivated by officials' recognition that a larger area of land had been vested in the Crown than Māori had intended. ${ }^{591}$

In the late 1940s and 1950s the government considered the future of these lands. In 1956 various proposals were formulated and Ngāti Tūwharetoa Trust Board was consulted. ${ }^{592}$ The Board advised the land had not been used for its intended purpose and should be returned to Māori, ${ }^{593}$ however nothing further was done for many years. In 1971, despite legal advice suggesting the gift had failed and the land should revert to Māori, the Department of Lands and Survey proposed the land be sold to the New Zealand Forestry Service subject to payment of a fair price to the Māori owners. ${ }^{594}$ The Secretary of Māori and Island Affairs was unequivocal in his view that the matter involved an important principle, and the Minister insisted on further consultation with Māori. ${ }^{595}$ Ngāti Tūwharetoa confirmed they opposed sale to the Crown and wanted the land returned. ${ }^{596}$

\footnotetext{
587 Memorandum, Commissioner of Crown Lands to Under-Secretary for Lands, 1 July 1918 and Letter, Gordon Coates to P Gray, 13 August 1926: National Archives, above n.

588 Native Land Amendment and Native Land Claims Adjustment Act 1930, s 25, consolidated in Native Purposes Act 1931, s 70.

589 See Ngāti Tūwharetoa, Te Kotahitanga O Ngāti Tūwharetoa and the Crown, Deed of Settlement of Historical Claims, 8 July 2017, at 71.

$590 \quad$ Native Purposes Act 1931, s 71.

591 Memorandum, Under-Secretary Native Department to Under-Secretary Department of Lands, 23 July 1931: National Archives, above n 586.

592 Report, Department of Lands and Survey to Minister of Lands, 3 December 1956: National Archives, above n 586.

593 Memorandum, Secretary for Maori Affairs to Director-General of Lands, 2 May 1958: National Archives, above n 586.

594 Letter, MacLachlan to Secretary for Maori and Island Affairs, 20 January 1971 and attached legal opinion of Heenan: National Archives, above n 586.

595 Letter, McEwan to Director-General of Lands, 9 March 1971: National Archives, above n 586.

596 Memorandum, Director-General of Lands to Commissioner of Crown Lands, 18 October 1972: National Archives, above $n 586$.
} 
The decision the land would be returned was announced by the Minister in 1973. ${ }^{597}$ The Maori Purposes Act (No 2) 1973 authorised the Minister of Lands to apply to the Māori Land Court to vest the land under a general provision in the Maori Affairs Act 1953 permitting the return of land taken from Māori for public works. The Māori Land Court was authorised to either vest the land in the persons found to be entitled to it, or in trustees for the benefit of such persons and their descendants. ${ }^{598}$ The full area of land taken was to be returned, being approximately 36,000 acres. The provision was acknowledged as important but was not debated at length in the House. Members were apparently satisfied with an acknowledgement the provision was important, and the explanation the government was giving effect to "a long-established principle" that gifted lands not used for their intended purpose should be returned to donors in the same manner as education sites were being dealt with. ${ }^{599}$

An application for a vesting order was duly made, however there were difficulties with putting governance arrangements in place, which necessitated multiple Māori Land Court hearings before the matter was finalised in 1975 with the establishment of several trusts. ${ }^{600}$ The delay in returning the Ōwhāoko gift blocks has been noted in the recent Ngāti Tūwharetoa Deed of Settlement. ${ }^{601}$

\section{$2 \quad$ Arahura River bed}

A different example can be seen in 1976 with the vesting of Arahura River bed in the Proprietors of Mawhera, which gave effect to a Crown promise the river bed would be returned to Māori. ${ }^{602}$ This provision was seen by the Member for Northern Māori as an acknowledgement that Māori should have control and management of their lands. ${ }^{603}$ Because the land had been recorded as Crown land, legislation was necessary to vest the land in Māori, to ensure a change in land status and to direct the issue of a new certificate of title. ${ }^{604}$ Inserted late in the parliamentary process by supplementary order paper, discussion of this provision was limited and did not convey the history of the claim or difficulties in respect of fishing rights that persisted for many years. ${ }^{605}$

\footnotetext{
597 "Big Block of Land is to be Returned to Maoris" Evening Post (Wellington, 11 June 1973): National Archives, above n 586.

$598 \quad$ Maori Purposes Act (No 2) 1973, s 23. This provision remains in force.

$599 \quad$ (13 September 1973) 385 NZPD at 3576 and 3581 and (15 November 1973) 388 NZPD at 5181.

$600 \quad$ Application by Minister of Lands - Owhaoko Gift Blocks (1975) 54 Tokaanu MB 108 (54 ATK 108).

$601 \quad$ Above n 589, at 72.

$602 \quad$ Maori Purposes Act 1976, s 27.

603 (8 December 1976) 408 NZPD 4645-4646.

604 (9 December 1976) 408 NZPD 4710 and Supplementary Order Paper 1976 (41) Maori Purposes Bill 1976 (100-1).

605 See Re Application by Beare and Perry for Mining Area in the Arahura River (1900) 2 GLR 242 (SC).
} 


\section{B Public Works Act Compensation}

There were a number of provisions in Māori Purposes Acts by which the Crown took land from Māori, vesting land in the Crown or deeming land to have been Crown land, and providing a mechanism for compensation to be assessed under the Public Works Act. ${ }^{606}$ The harsh impact of public works takings and low compensation provided to Māori has been identified by the Waitangi Tribunal. ${ }^{607}$ A Māori Purposes Act provision that gave rise to a grievance within the modern Treaty of Waitangi settlement process was the vesting of Wharewaka Reserve in the Crown. Although Māori petitioned for the return of the land, which remained within Crown control, the Crown retained the land and allowed for compensation to be assessed under the Public Works Act. ${ }^{608}$

\section{$1 \quad$ Whaiti-Kuranui}

A particularly good example of these provisions and the compensation issues that followed was the vesting of land known as Whaiti-Kuranui in the Crown. This example illustrates some themes of earlier settlement provisions including delayed discovery of the problem giving rise to the claim, leaving Māori without a legal remedy, and the Crown's reluctance to take responsibility for an acknowledged error.

The claim resulted from a survey error that occurred in 1905 when the boundary between Crown and Māori land was being re-defined, which resulted in 31 acres of Māori land being wrongly included in the area the Crown was acquiring for settlement. ${ }^{609}$ The land was sold to third parties with the exception of one area held under a renewable lease. When the survey error was discovered years later by the Chief Surveyor, the Department of Lands and Survey proposed the Crown buy the land from Māori at the unimproved value at the time the error occurred and set-off outstanding survey costs to reduce the purchase price. ${ }^{610}$ The Native Department argued a current valuation should be used and survey liens

606 Native Purposes Act 1940, s 8 (Te Akau School reserve) and Maori Purposes Act 1951, s 32 (customary land in the Coromandel). See also Native Purposes Act 1946, s 13 (Kaipara River works).

607 Cathy Marr "Public Works Takings of Maori Land, 1840-1981" (Waitangi Tribunal, Rangahaua Whanui Series, May 1997) ch 11, especially at 206-221.

608 Native Purposes Act 1938, s 9. See Native Land Court "Report and Recommendation on Petition No 123 of 1936, of Waaka Te Arakai and Others, so far as it relates to Wharewaka Reserve" [1937-38] II AJHR G6D. See Deed of Settlement, above n 589, at 35-37.

609 The confusion surrounding the surveying and title process in respect of Whaiti-Kuranui has been the subject of historical investigation: Brian D Gilling "The Purchase of the Patetere Block 1873-1881: An Exploratory Report" (Wai 1200, November 1992).

610 Letter of Under-Secretary Department of Lands and Survey, 4 June 1931, Memorandum, Chief Surveyor to UnderSecretary for Lands, and Letter, Wallis to Valuation Department, 30 January 1932: AECZ 18714 MA-MLP1/262/g (1931/8). 
left for later discussion. ${ }^{611}$ Māori owners rejected a subsequent offer of compensation at the unimproved land value based on a current valuation. ${ }^{612}$

The issue was not progressed until 1939 when the Crown's hand was forced by the lessee seeking to exercise rights in respect of the lease. The Department of Lands again sought special legislation to enable the land to be taken, proposing that compensation under the Public Works Act be determined and applied to outstanding survey liens. ${ }^{613}$ The Native Minister was concerned about this approach because of a petition referred for inquiry that encompassed the Whaiti-Kuranui land, ${ }^{614}$ and insisted a meeting of owners be called so the situation could be fully explained to them. ${ }^{615}$ Very few owners attended the meeting. Those who did attend agreed by slim majority to sell the land subject to return of a burial ground on the land. The Crown official convening the meeting interpreted poor attendance of the vast majority of owners as a lack of interest, which indicated owners were willing to allow the Crown to resolve the situation. ${ }^{616}$ The Crown secured the return of the burial ground to Māori with the cooperation of the third-party who owned the land. ${ }^{617}$ In response to pressure from solicitors for the lessee, ${ }^{618}$ the Native Purposes Act 1942 vested the balance of the land in the Crown with provision that compensation was to be assessed as if the land had "presently been taken" under the Public Works Act 1928. ${ }^{619}$ This approach protected the Crown's position and allocated all risk to Māori. The provision was not debated in the House; all provisions of the bill were described by the Minister as not being of "such an outstanding character as to call for any special notice". ${ }^{20}$

In the compensation hearing the Crown sought to limit compensation to the "present unimproved value" of the land plus rental received by the Crown since 1905, amounting to approximately $£ 145$. The Court took notice of Māori protest to the taking of their land, particularly the burial site, and concluded there was no legal basis to argue Māori should not receive full compensation for the loss of their land as if

611 Memorandum, Under-Secretary Native Department to Under-Secretary of Lands, 27 July 1933: National Archives, above n.

612 Memorandum to Rotorua Native Land Court Registrar, 21 March 1935: National Archives, above n 610.

613 Letter, Under-Secretary of Lands and Survey to Under-Secretary Native Department, 7 September 1939: National Archives, above n 610. Native Purposes Act 1939, Schedule, cl 1 (petition 113/1938). Memorandum, Native Minister to Under-Secretary, 2 July 1940: National Archives, above n 610. Memorandum of H Tai Mitchell, 7 November 1940: National Archives, above n 610. Memoranda, Under-Secretary Lands and Survey to Under-Secretary Native Department, 24 April 1942 and 23 July 1942: National Archives, above n 610.

618 Letter, Commissioner of Crown Lands to Under-Secretary Crown Lands, 7 September 1942: National Archives, above n 610 . Native Purposes Act 1942, s 7. See Letter, Under-Secretary Native Department to Minister, 15 January 1941 : National Archives, above n 610.

$620 \quad$ (19 October 1942) 261 NZPD 793. 
presently taken, as provided by the legislation. The Court awarded Māori $£ 496$ and considered it unnecessary to apportion compensation to the Crown for loss of security for outstanding survey liens. ${ }^{621}$

\section{Conclusions}

Examination of settlements and remedial provisions in Māori Purposes Acts confirms these remedial provisions were almost invariably entered into by the Crown in the absence of enforceable legal rights by Māori, and usually without reliance on the Crown's obligations under the Treaty of Waitangi even if raised as an issue during negotiations. Remedies were provided on the basis of notions of fairness, equity and moral obligation, whether assessed by Royal Commissions, Crown officials or Ministers. In some cases, the reasoning upon which a remedy was recommended or agreed to was obscure and may have reflected an undefined sense of wrong.

Settlement provisions fall within Llewellyn's first law-job of resolving trouble-cases. Legislative provisions to resolve claims were usually necessary because of the absence of a general legal framework to attach to, and because the government wanted certainty and finality in situations where there might otherwise be doubt. Some provisions provided for governance structures, and frequently the Māori Land Court was empowered to determine ownership claims to the compensation provided or lands returned, which could be a difficult task. As indicated at the outset of this chapter, this aspect of settlement provisions also falls within Llewellyn's third law-job of allocating authority.

Remedies were hard won and did not fully compensate Māori. The Crown was reluctant to resolve claims even when those claims were recognised as well-founded, and the return of land to Māori was either not the Crown's preferred option or was complicated by the rights of third parties. For Māori this usually meant the best they could achieve was compensation. Compensation was limited to the value of the land lost, often with provision for interest and some costs, but without recognition of any consequential loss or the stress or suffering Māori endured. ${ }^{622}$ In the absence of an independent decisionmaker or an authority to which it was accountable, the Crown was able to delay settlements, secure benefits to itself and barter down reparations, which is inconsistent with notions of justice. Few remedial provisions in Māori Purposes Acts could be described as restoring Māori to the position they had been in before the event giving rise to the claim occurred, and balance was not restored in New Zealand society. It is unsurprising many claims were revisited in the modern Treaty of Waitangi settlements process. When the Crown's obligations were measured in terms of Treaty of Waitangi obligations, Crown responses were found to be inadequate, which is acknowledged in modern settlements. 
Although remedial provisions failed to achieve justice in most cases, they evidence the Crown's awareness of the need to resolve persistent, long-standing grievances for the benefit of Māori and New Zealand society. In later years some remedial provisions reflected policies that had developed to return land to Māori, notably in the case of schools. Provisions took steps towards justice, and Māori pragmatically took what they could get, accepting "half a loaf was better than no bread". ${ }^{623}$ The legislative process did not involve considered discussion of the claims resolved by Māori Purposes Acts or what the totality of these provisions revealed about the ability of New Zealand's legal system to provide justice to Māori for recognised wrongs. This lack of attention and limited awareness either resulted from, or was exacerbated by, mischaracterisation of the legislation as merely "washing-up"; a characterisation that did not reflect the significance of claims provisions.

623 Member for Gisborne, Esme Tombleson in respect of the Ngāi Tahu claim, cited by Hill "Settlements of Major Maori Claims", above n 82, at 12. 


\section{Chapter 8: Special Governance Arrangements}

\section{Introduction}

The Native Purposes Act 1931 contained a number of provisions that continued special governance arrangements in place for Māori. Provisions included those governing private trusts such as Wi Pere Trust, and the first statutory trust boards established for the purpose of receiving compensation for claims against the Crown, such as Ngāti Tūwharetoa, Arawa District and Ngāi Tahu trust boards. The 1931 Act consolidated provisions governing the Commissioner of the East Coast Native Trust, and continued governance arrangements for particular boards such as the Māori Ethnological Research Board and Kaiapoi Reserve Board governing Kaiapoi Pā. These governance arrangements were "special" in the sense they sat outside the general legal framework for Māori land. In the case of trusts and trust boards this was because no general framework existed. ${ }^{624}$ Many of these governance provisions were the legacy of Māori claims against the Crown or resolved problematic situations.

Subsequent provisions in Māori Purposes Acts often adjusted existing governance structures or transitioned the original arrangements to a new legal structure in response to problems or requests by Māori. This was due to a combination of reasons including arrangements not achieving the autonomy Māori wanted or proving unworkable, and in some cases the general legal framework had developed to the point that it provided an alternative to special governance provisions. This can be seen with the introduction of the Maori Trust Boards Act 1955, at which time provisions dealing with Māori statutory trust boards were removed from Māori Purposes Acts and placed under the new Act. Some of the changes to governance frameworks progressed Māori autonomy, removing restrictions and providing for Māori representation, and some provisions returned land to Māori management, such as the release of lands from the East Coast Commissioner. ${ }^{625}$

The number of special governance arrangements in Māori Purposes Acts in comparison with the overall number of Māori incorporations and trusts is small and these provisions could be considered anomalies. ${ }^{626}$ Many governance arrangements attempted to accommodate or progress Māori autonomy, although they were rarely enacted with the Crown's obligations under the Treaty of Waitangi in mind. Special governance provisions, while often moving towards Māori self-management, developed in an ad

\footnotetext{
$624 \quad$ See above nn 293-321.

625 See Mangatu, below nn 723-734, and provisions in Maori Purposes Act 1951, Pt II.

626 See Report of Royal Commission, above $\mathrm{n} 226$, at 26. It is outside the scope of this thesis to consider whether these provisions were evidence of pluralism or merely reflect legal diversity: see discussion by Jones, above $\mathrm{n} 80$, at $42-$ 50.
} 
hoc and unprincipled fashion. These arrangements were not usually flexible enough to incorporate principles of Māori law or tikanga, a problem that persists into modern governance structures. ${ }^{627}$

In this chapter I examine examples of special governance provisions in Māori Purposes Acts, focusing on the content and origins of those arrangements, which vary from being the outcome of settlements, petitions or direct advocacy, many of which remain in force. I consider why special provisions were enacted outside of the general legal framework and how well these particular provisions responded to Māori needs and wishes at the time.

\section{An Inspirational Example: Wi Pere Trust}

In 2017 Wi Pere Trust was heralded by almost all speakers in the House during the third reading of the Māori Purposes Bill 2017 as a modern example of successful Māori governance, one that would serve as a model and inspiration for other Māori organisations wanting to achieve autonomy over their affairs. $^{628}$

This private trust was initially established in 1899 by Māori politician Wi Pere to save family lands from the impact of his potential bankruptcy. ${ }^{629} \mathrm{Wi}$ Pere Trust is one of the earliest Māori trusts, established before general legislative provision authorising the establishment of Māori trusts. ${ }^{630}$ From relatively early on a family representative was appointed as one of the trustees. ${ }^{631}$

Wi Pere Trust first appeared in Māori Purposes legislation in 1931 when provision was made enabling the Governor-General to replace trustees and declare fresh trusts. ${ }^{632}$ Extensive changes were made to the Trust's special governance framework in 1938. These changes were prompted by uncertainty about whether the original terms of the trust remained in force and concerns expressed by the Native Land Court about the validity of trustees delegating powers and receiving remuneration in the absence of express permission in the trust deed. ${ }^{633}$ Beneficial owners were consulted about the proposed legislation,

$627 \quad$ See Jones, above n 80, ch 5.

628 (4 May 2017) 721 NZPD 17713-17731.

629 Joseph Anaru Te Kani Pere Wiremu Pere: The Life and Times of a Maori Leader 1837-1915 (Oratia, Auckland, 2010) at 151-152.

$630 \quad$ Above nn 293-321.

631 Māori Purposes (Wi Pere Trust) Act 1991, s 2.

$632 \quad$ Native Purposes Act 1931, s 61.

633 Report of Chief Judge, 24 September 1937: National Archives, AAMK 869 W3074/806/a (26/10) and Wi Pere Trust (1937) 64 Gisborne MB 104 (64 GIS 104). See also Re Foster's Caveat (1907) 26 NZLR 890 (SC) at 894. 
and indicated they wanted to approve any sale or lease of land, and were unhappy the Native Trustee may be appointed a trustee. ${ }^{634}$ These concerns did not prompt changes to the proposed framework.

The special governance model created for Wi Pere Trust in 1938 provided trustees with restricted discretion to govern. ${ }^{635}$ The Governor-General continued to be responsible for the appointment and removal of trustees, and trustees' term of office was indeterminate. The legislation contained prescriptive provisions directing how the trustees were to apply income earned by the trust. Financial statements were required to be audited under the control of the Native Minister. All lands were deemed to be Native freehold land, a provision for which there was no parallel in the principal legislation. This change clarified the status of the lands but did not engage protections in the Native Land Act 1931, which were not incorporated within the regime. ${ }^{636}$ The regime contained its own specific restriction on alienation by sale, enabling trustees to sell land with the Minister's consent, on the recommendation of the Native Land Court. Following regular meetings between trustees and beneficial owners to set the direction of the trust under the new legislation, although not all issues were agreed, the administration of the trust and satisfaction of the beneficiaries was considered to be improved. ${ }^{637}$ This provision was inserted while the Bill was before the Committee and only briefly mentioned in the House. ${ }^{638}$

In 1950 and 1973 adjustments were made to the trust to enable the transfer of beneficial interests to descendants and other beneficiaries, and to validate such transfers after a gap in the machinery to effect transfer was identified. ${ }^{639}$ The provision in the principal legislation initially relied on was not broad enough to deal with assets other than the Māori land, demonstrating one of the potential risks of a special regime sitting outside principal legislation; that not all technical issues will be identified and provided for. The lack of debate in 1950 did not assist the situation, with the provision identified as "machinery". 640

In the 1970s, trustees raised various issues about the governance of the trust with the Department, including the method of appointment of trustees and their desire to formalise the practice of restricting succession to lineal descendants of Wi Pere. These approaches invariably resulted in the Department and Minister pointing out that the statutory purpose of repaying Wi Pere's debts had been fulfilled and the Trust could not continue indefinitely. The suggestion the Trust become a Māori incorporation within

\footnotetext{
634 Report, above $\mathrm{n}$.

$635 \quad$ Native Purposes Act 1938, s 15.

636 See Native Land Act 1931, Part XIII.

637 Letter, Clerk to Trustees, 20 December 1939: National Archives, above n 633.

638 Above $\mathrm{n} 560$.

639 Maori Purposes Act 1950, s 60 and Maori Purposes (No 2) Act 1973, s 22. See Letter, Under-Secretary to Minister, 7 May 1973: National Archives, AAMK 869 W3074/808/a (26/10).

$640 \quad$ (29 November 1950) 293 NZPD 4722 and 4728.
} 
general legislation was repeatedly made. ${ }^{641}$ The trustees resisted this pressure, making it clear the special legislation had been the means of the Trust's "salvation and success."

By 1974 two family members had been appointed of the three trustees, and there was a desire for more family members to be involved in the governance of the trust. In 1985, trustees engaged again with the Department, outlining proposed legislative changes for discussion. ${ }^{643}$ It took some years for the legislative proposal to be progressed, but a bill was presented to Parliament in 1988. The trustees' requests for changes to the bill formed the basis of all the changes made to the bill by the Committee as reported back to Parliament. ${ }^{644}$ To the extent submissions from beneficial owners differed from the view of trustees, the Committee was advised by officials to follow the trustees' instructions. ${ }^{645}$

The process of enacting the Maori Purposes Act 1991 was the longest in the history of the Māori Purposes legislation, but the trustees were successful in achieving their key goals within the existing trust structure. There was significant debate of the legislation and general support in the House for the amendments, including the provision confining succession to lineal descendants of Wi Pere, which was supported as accommodating the wishes of trustees, beneficial owners and Māori custom. ${ }^{646}$ Adopted children and spouses were only able to inherit life interests, which was considered consistent with the proposed Maori Affairs Bill. ${ }^{647}$ Another key change was to the trustee appointment process, which was modified to allow for an increase in the number of trustees and appointment for a determinate period to ensure regular rotation of trustees. Future appointments were to be made by the Minister on the recommendation of trustees. Provisions limiting trustee powers and directing how the income of the trust was to be dealt with were removed and replaced with general powers under the Trustee Act $1956 .{ }^{648}$ Unfortunately, not all empowering provisions in the Trustee Act were incorporated, which necessitated a further amendment in 1994, initiated by private member's bill. ${ }^{649}$ Ministerial oversight was retained in respect of the annual accounts and expenses.

In 2008 the trustees approached the Minister of Māori Affairs about the need to make further structural changes to the Trust's governance structure to allow for greater commercial flexibility and to clarify

\footnotetext{
641 See various correspondence: National Archives, AAMK 869 W3074/808/a and b (26/10).

642 Submissions of Trustees to Minister, 2 November 1971: National Archives, AAMK 869 W3074/808/a (26/10).

643 Letter, Wi Pere Trust to Maori Trustee, 2 May 1985: National Archives, ABJZ 869 W4644/68 (26/10).

644 Letters of Wauchop, Kohn \& Co, 18 and 26 January 1989: National Archives, ABGX 16127 W4731/325 (MA/2/4/2). See Maori Purposes Bill 1989 (121-2) (select committee report), cl 2.

645 Letter from Department of Maori Affairs, 1 May 1989: National Archives, ABGX 16127 W4731/325 (MA/2/4/3).

646 (28 November 1989) 503 NZPD 13770-13778; (3 April 1990) 506 NZPD 1285-1290. Letter, Secretary of Justice to Maori Affairs Select Committee, 14 August 1989: National Archives, above n 644.

$648 \quad$ Maori Purposes Act 1991, s 2.

649 Maori Purposes (Wi Pere Trust) Act 1994. See (26 May 1994) 540 NZPD 1139-40.
} 
Trust practice. ${ }^{650}$ The bill was developed by the Department to meet the requirements of the trustees over a lengthy period of close consultation with trustees, ${ }^{651}$ who consulted with beneficial owners. ${ }^{652}$

The removal of all Ministerial involvement in the Trust, promoting self-determination, was strongly supported by most parties throughout the Parliamentary process. The Trust was permitted to remain a statutory trust within its own special legislative regime, to retain its historic identity and the trust concepts familiar to trustees and beneficiaries. The trustees were incorporated as a trust board to secure administrative and other advantages. ${ }^{653}$

The 2017 legislation contained a provision reverting lands with general land status on acquisition by the Trust but deemed to have Māori freehold land status, back to general land status. Although this provision caused initial concern among some Members of the House and beneficial owners, ${ }^{654}$ it was accepted the provision would not affect Wi Pere's original lands. The change was intended to release lands acquired in the 1960s and 1970s from Māori freehold land status so that they could be dealt with more freely, as investment lands held by Māori incorporations and trusts could be. Wi Pere's ancestral lands, and lands acquired with Māori freehold status were to be protected from alienation, which was expressly stipulated in the legislation. ${ }^{655}$

The Act clarified the uncertain relationship between the Trust's special legislation and the provisions of Te Ture Whenua Maori Act 1993 and provided the trust was not subject to the rule against perpetuities. One of the key improvements effected by the legislation was incorporation of the Trust's internal governance processes and formalisation of the role of beneficial owners in the operation of the Trust. ${ }^{656}$ The new trust board was required to adopt a constitution dealing with matters such as annual general meetings, election of trustees and their retirement, and dispute resolution. The first constitution was included in the legislation and it incorporated elements of process drawn from the companies' model. For example, beneficial owners were given approval over alienations by way of a major transactions clause. $^{657}$ and-laws/bills-proposed-laws/document/00DBHOH_BILL64510_1/tab/submissionsandadvice>. (15 September 2015) 708 NZPD 6620.

$652 \quad$ Above $\mathrm{n}$ and above $\mathrm{n} 650$, at 5 .

653 Māori Purposes Act 2017, s 9 inserting new sections 6-17. See above $n$.

$654 \quad$ (15 September 2015) 708 NZPD 6622, 6627 and 6631.

655 (18 August 2016) 716 NZPD 13052-13656. Māori Purposes Act 2017, s 9 inserting new ss 30-41.

656 Māori Purposes Act 2017, Pt 1.

657 Māori Purposes Act 2017, ss 9 and 10, inserting new s 15 and Schedule 1. See Companies Act 1993, s 129. 
The provisions restricting succession to lineal descendants of Wi Pere were clarified to remove any doubt as to the intention and application of the provision. This amendment required assessment against the New Zealand Bill of Rights Act 1990, which had not occurred in the passage of the Maori Purposes Act 1991. The Attorney-General indicated the provision confining succession to lineal descendants could be considered discrimination on the basis of family status in breach of the Act, because of differential treatment of adopted children, but concluded Māori should be permitted to determine their own membership in accordance with tikanga and any differential treatment was justified. ${ }^{658}$

The Committee made several changes to the bill, including changes of a technical nature, largely in response to issues raised by beneficial owners. Such changes included expanding the proposed jurisdiction of the Māori Land Court, adding a five-year review of the Trust's constitution to promote further consultation with beneficial owners, and enabling beneficiaries to propose special resolutions. ${ }^{659}$

The careful scrutiny and attention paid to the passage of the Māori Purposes Act 2017 stands in stark contrast to earlier Māori Purposes Acts where insufficient attention was paid to technical matters, resulting in poor legislation and errors requiring correction. The legislative process involved extensive consultations with trustees, and beneficial owners with concerns engaged in the process, which the Committee dealt with on merit. The 2017 legislation rests at the end of a long period of legislative interventions at the behest of trustees, slowly moving the Trust towards independence from the state and to autonomy, respecting the aspirations of trustees and beneficiaries to retain their special governance framework.

\section{Protecting Exclusive Rights: Lake Rotoaira}

The Māori Purposes Acts contain provisions granting and protecting exclusive fishing rights for Ngāti Tūwharetoa in Lake Rotoaira. The special regime protecting Ngāti Tūwharetoa's fishing rights in Lake Rotoaira was a rare illustration of the Crown's willingness to take action to protect Māori interests, expressed to reflect Treaty obligations, which is why I have chosen it as an example of special governance arrangements.

The exclusive fishery was a means of compensating the tribe for damage to their fisheries, and regulations to protect the fishery were authorised by legislation. ${ }^{660}$ Deliberate testing of the validity of those

\footnotetext{
$658 \quad$ (15 September 2015) 708 NZPD 6622-6623.

659 Māori Purposes Bill 2015 (44-2) (select committee report) at 1-5.

660 Native Purposes Act 1931, s 68, consolidating Native Land Amendment and Native Land Claims Adjustment Act 1921-22, s 28. See Deed of Settlement, above n 589, at 81, 105-109 and 124. See also Memorandum, UnderSecretary to Minister of Maori Affairs, 17 May 1957: National Archives, ACIH 16036 MAW2459/178 (19/1/344).
} 
regulations by Europeans resulted in further legislative provision in 1938 outlining Ngāti Tūwharetoa's exclusive rights regardless of any general laws applying to fishing, and establishing a fine for breach of those rights. ${ }^{661}$

The regime was subsequently adjusted to deal with various problems at the instigation of Ngāti Tūwharetoa. Adjustments included increasing the penalty for illegal fishing to discourage breaches of the law and permitting Ngāti Tūwharetoa Trust Board to retain most of the fines. ${ }^{662}$ Because no practical means by which the tribe could enforce its rights had been provided for in the legislation to date, ${ }^{663}$ further provisions empowered the Board to appoint rangers to enforce the restrictions and created an additional offence. ${ }^{664}$

Following the creation of the Rotoaira Trust and vesting of title in trustees, the trustees sought legislative amendments enabling them to open the lake for public fishing to secure an income for the tribe. ${ }^{665}$ The Maori Purposes Bill 1959 proposed empowering the trustees to set entry fees to access the lake and impose conditions on entry, and amending the regime to reflect the new trust. ${ }^{666}$ The regime was to be subject to regulations issued by the Governor-General, which were prepared by counsel for the trustees, along with the legislation, for approval by the Department. ${ }^{667}$

In contrast to previous provisions which did not attract attention in the House, multiple concerns were raised about these provisions, including concerns Ngāti Tūwharetoa were being given wide powers and special concessions. ${ }^{668}$ The Opposition party argued that allowing Ngāti Tūwharetoa to charge an entry fee to access the lake was tantamount to selling the right to fish, which was prohibited under the Fisheries Act. ${ }^{669}$ The arrangement was initially conceived of as permitting a special exception to general laws. ${ }^{670}$ However, in the House the Prime Minister justified the special provisions by arguing the Treaty of Waitangi reserved lakes for the benefit of Māori, which had to be considered, and he distinguished

\footnotetext{
$661 \quad$ Native Purposes Act 1938, s 22.

662 Maori Purposes Act 1947, s 48. See (26 November 1947) 279 NZPD 1090 and Memorandum, 11 November 1947, Under-Secretary to Native Minister: National Archives, above n 660.

663 Letter, McKenzie \& Knapp to Under-Secretary, 21 November 1944, and Memorandum, Under-Secretary to Minister of Maori Affairs, 5 March 1948: National Archives, above n 660.

664 Maori Purposes Act 1948, s 12.

665 Notes on Deputation by Trustees of Lake Rotoaira, 12 April 1957: National Archives, above n 660. See also Deed of Settlement, above n 589, at 105-109.

$666 \quad$ Maori Purposes Bill 1959 (93-1) (explanatory note), cl 15.

667 Letter, Tripe to Minister of Maori Affairs, 11 February 1959: National Archives, above n 660.

668 (14 and 15 October 1959) 321 NZPD 2446 and 2459-2462.

$669 \quad$ See Fisheries Act 1908, s 89.

670 Notes, above n 665 and see Memorandum, Under-Secretary to Minister of Maori Affairs, 17 May 1957: National Archives, above n 660 .
} 
between selling fishing rights and charging for access to private land, which he argued all landowners were free to do. ${ }^{671}$

The legislation was enacted without amendment. ${ }^{672}$ The provision was an important recognition of Treaty obligations and a concession to Māori autonomy, which created exclusive rights, the breach of which could result in punishable offences. However, it was incorrect to suggest Ngāti Tūwharetoa were given wide powers or unfettered authority to control fishing on the lake. The fishing regulations were extensive, requiring trustees to work within the general fishing limits of the local area. ${ }^{673}$

Further changes to the legislative regime were necessitated by the impact of the Tongariro Power Scheme Development, which required redefinition of the waters comprising Lake Rotoaira to ensure fishing could continue when water levels rose. ${ }^{674}$ This problem was identified by Ngāti Tūwharetoa. ${ }^{675}$ The legislative solution was introduced to the House as "a housekeeping measure" in a bill "designed to help the Maori people". ${ }^{676}$ The clause did remedy the immediate problem, but this characterisation ignores the context that gave rise to the problem, which is indicative of the manner in which many important provisions in the Māori Purposes Acts were presented to the House. The provision was later acknowledged to be the outcome of lengthy negotiations with trustees, and one that preceded an "unsettled claim" for compensation. ${ }^{677}$

The significance of the 1959 provisions was recognised in the House, but the debate did not demonstrate a sound understanding of the provisions, with colonial attitudes dominating objections. The governance structure of the regime, as amended in 1959, remains in force. However, the durability of the framework did not preclude Ngāti Tūwharetoa's dissatisfaction with the Crown's behaviour in respect of the power scheme, which caused damage to Lake Rotoaira and the fishery, and became the subject of a Treaty of Waitangi claim. ${ }^{678}$

$671 \quad$ (15 October 1959) 321 NZPD 2462.

$672 \quad$ Maori Purposes Act 1959, ss 2-16.

$673 \quad$ Rotoaira Trout Fishing Regulations 1959.

$674 \quad$ Maori Purposes Act 1977, s 9.

675 See Letter, Tripe, Matthews \& Feist to Secretary for Maori Affairs, 28 July 1976, and Memorandum of Office Solicitor, 8 August 1976: National Archives, ABJZ 869 W4644/172 (43/1/13).

$676 \quad$ (24 November 1977) 416 NZPD 4740 and 4746.

677 (16 December 1977) 416 NZPD 5436.

678 Deed of Settlement, above n 589, at 105-109. 


\section{Hybrid Governance Structures}

There are several examples of governance frameworks within Māori Purposes Acts that combine elements of different existing governance models to create specific governance arrangements to accommodate Māori aspirations and preferences. While such arrangements offered advantages in comparison with the prescriptive general framework, difficulties could arise due to ill-fit with the general legal regime, necessitating adjustments.

\section{A Poho-O-Rawiri Marae}

The governance arrangements for Poho-O-Rawiri Marae provide an example of a special legislative regime in Māori Purposes Acts originating from a dispute with the Crown. The Crown's attempt to take land from Māori for the purpose of Gisborne Harbour exceeded what was legally legitimate, and was challenged by Māori. ${ }^{679}$ The situation was resolved by a negotiated agreement for the sale of the land, ${ }^{600}$ with statutory provision authorising disposal of the land and giving effect to the agreement. ${ }^{681}$ This provision was partially consolidated in the Native Purposes Act 1931, which continued the obligations of Tairāwhiti District Maori Land Board to acquire and manage a new pā site, and hold any funds on trust for the beneficial owners. The provision also confirmed the Native Land Court's ability to appoint a committee of Māori to advise the Board. ${ }^{682}$

A new pā site was subsequently acquired, and by 1950 the trust funds had been depleted. The Board requested legislative authority vesting the land in beneficial owners, stating there was no reason for the trust to continue, which was agreed to by the Department. ${ }^{683}$ The Maori Purposes Act 1950 authorised the Māori Land Court to make orders discharging the Board from the trust, and the Court was given broad responsibility to ascertain the beneficial owners of the land and vest the land in them directly or in trustees. ${ }^{684}$ This provision was considered to be merely machinery and was not debated in the House. ${ }^{685}$ An order establishing a section 438 trust was made in accordance with the legislation in favour of five

\footnotetext{
679 Report of Chief Judge, 24 August 1927: National Archives, AAMK 869 W3074/664/a (19/1/254). See also Kaiti 38 and 39 (1927) 56 Gisborne MB 54 (56 GIS 54).

680 Deed, 12 October 1927: National Archives, above n.

681 Native Land Amendment and Native Land Claims Adjustment Act 1927, s 51 (originally known as Kaiti Pa).

$682 \quad$ Native Purposes Act 1931, s 62.

683 Memorandum Under-Secretary to Minister of Maori Affairs, 10 May 1950: National Archives, above n 679.

$684 \quad$ Maori Purposes Act 1950, s 59.

685 Above n 640.
} 
tribes, with the intention a Māori incorporation would be formed immediately thereafter under general legislative provisions. ${ }^{686}$

A Māori incorporation was subsequently formed in favour of the five tribes, but changes to the general framework governing Māori incorporations in 1967 caused difficulties. ${ }^{67}$ The advisory committee was concerned the land was changing to European land status, but the primary concern was the absence of a list of individual shareholders from which to create a share register, raising compliance issues. ${ }^{688}$

The agreed solution was to implement a hybrid governance structure based on a precedent in the Native Purposes Act 1931, the Rewi Maniapoto Memorial Trust. This trust was governed by a committee constituted as a body corporate, which held land on trust for the specific purpose of maintaining a memorial, not for beneficial owners as an incorporation model would have required. A number of special arrangements were implemented that differed from the incorporation model, but the committee was given the powers of a body corporate as if constituted as a Māori incorporation. ${ }^{69}$ This was not the only example of a hybrid governance arrangement in the 1931 legislation. The Ringatu Church was governed by trustees who also had the powers of a committee of management as if a body corporate. ${ }^{690}$ Both of these frameworks remain in place today.

In the case of Poho-o-Rawiri Marae, the new framework enacted set the land apart as a Māori reservation under the general law for the benefit of the five tribes named in the trust order, pursuant to s 439 of the Maori Affairs Act 1953. ${ }^{691}$ At the time, section 439 did not provide for the creation of a reservation for the express purpose of a marae, which necessitated special legislation. ${ }^{692}$ Application of the reservation framework ensured the land, regardless of its status, would be managed as a reservation and underlying ownership did not need to be vested in individuals. The other beneficial aspect of the framework was to provide that members of the existing committee of management formed a new marae committee, constituted as a body corporate. The legislation applied the general Māori incorporation framework to the operation of the committee, subject to specific provisions about meetings and a provision which permitted some of the land to be alienated, which was not available within the general framework. ${ }^{693}$

See Memorandum, Secretary to Minister of Maori Affairs dated 27 September 1954, Trust Order, 1 September 1954 and Order of Incorporation, 9 November 1954: National Archives, AAMK 869 W3074/664/b (19/1/254). See above $\mathrm{n} 340$.

Memorandum of Judge Haughey, 12 May 1969, and Letter, Robinson to Under-Secretary, 4 September 1969: National Archives, above n 686.

Native Purposes Act 1931, s 50.

Native Purposes Act 1931, s 57.

Maori Purposes Act 1970, ss 26-31.

Reference to "marae" was later added by the Maori Purposes Act (No 2) 1973, s 15(1)(b).

Only short-term leases and licences were permitted: Maori Affairs Act 1953, s 439(9) and (9A). 
The existing Māori incorporation was dissolved. This provision was mentioned in the House by the Member for Gisborne and interpreted as positive because it reflected Māori wishes. ${ }^{694}$

This governance structure remains in place today. The Poho-O-Rawiri Marae governance structure and precedent examples discussed further illustrate the Crown's occasional willingness to manipulate legal frameworks to create bespoke governance structures, accommodating Māori wishes to incorporate the aspects of each framework that best met their needs.

\section{B Other Examples}

Another example of governance provisions in Māori Purposes Acts that attempted to establish a fit for purpose special regime were those in respect of Ratana Pā. The Ratana Trust Board was established in 1941 with wide powers similar to those of local government, described as a "worthwhile experiment" ${ }^{695}$ The regime proved ineffective, which was attributed in the House to the lack of security of tenure preventing those in the settlement from obtaining finance to build homes. ${ }^{696}$ The Member for Western Māori advocated for a solution, which resulted in legislation authorising the establishment of section 438 trusts governed by specific provisions. The legislation authorised sales and leases of land without requiring confirmation from the Māori Land Court. The regime was to be subject to general local government laws and the provisions of the Maori Social and Economic Advancement Act 1945, under which subsidies had been secured in 1950. ${ }^{697}$ The arrangements for Ratana Pā were recognised as important and were the focus of debate before the House. ${ }^{698}$ Various trusts remain in place. ${ }^{699}$

A more cautionary example of a special regime created in response to Māori advocacy is seen with provisions in 1962, which amalgamated titles of settlement reserves on the West Coast into one equitable title held in common ownership by beneficial owners, known as Parininihi ki Waitotara Reserve. ${ }^{700}$ This legislative arrangement differed from the policy of the general framework in the Maori Reserved Land Act 1955, which recognised the separate beneficial interests of owners. The other key feature of the special arrangement was that uneconomic interests were to be vested in the Taranaki Māori Trust Board and held on trust for educational purposes. ${ }^{701}$ Some concerns about the arrangement were expressed

\footnotetext{
$694 \quad$ (12 November 1970) 370 NZPD 4917.

$695 \quad$ Native Purposes Act 1941, s 14 and see (8 October 1941) 260 NZPD 1062.

$696 \quad$ (27 September 1954) 304 NZPD 1964-1969.

697 Maori Purposes Act 1954, s 5. Above n, at 1967-1969. See also Maori Purposes Act 1950, s 12.

698 (27 September 1954) 304 NZPD 1964-1969.

699 See <http://www.maorilandonline.govt.nz/gis/title/search.htm>.

$700 \quad$ Maori Purposes Act 1962, ss 3-8.

$701 \quad$ Maori Purposes Act 1962, ss 3(4), and 4-7.
} 
when the provision was discussed, but the House was assured the owners wanted and supported the legislation. ${ }^{702}$ The Committee endorsed the arrangement provided the Board adjusted its policy of restricting benefits to local Māori, so that children of all owners who lost uneconomic interests would be entitled to educational benefits. ${ }^{703}$ These provisions were amended the following year by allowing interests in the reserve to be held in family arrangements, which limited the loss of uneconomic interests. ${ }^{704}$ The special arrangements were repealed in 1967. Questions have subsequently been raised about the authority and adequacy of the owners' mandate in $1962,{ }^{705}$ and the harm caused by severing beneficial owners' direct relationship with the land. ${ }^{706}$

\section{Returning Land to Māori Control}

A number of special governance provisions in Māori Purposes Acts returned land managed for Māori, and over which Māori had no formal voice and little control, to Māori in response to the desire of beneficial owners to manage their own lands. Not all examples can be considered in detail. ${ }^{707}$ An important example not selected for consideration were the governance arrangements for Rangatira Blocks in Taupō in response to Royal Commission recommendations, ${ }^{708}$ described as illustrating the government's policy of returning land to Māori management and control. ${ }^{709}$ Legislative provisions returning land to Māori control were well motivated, but not without difficulties. Two contrasting examples of governance arrangements have been chosen for further analysis, both of which have endured.

\footnotetext{
702 (30 November 1962) 333 NZPD 2994 and (5 and 13 December 1962) 333 NZPD at 3107 and $3353-3357$.

703 (5 December 1962) 333 NZPD 3106.

704 Maori Purposes Act 1963, s 17. See Letter, District Officer to Horner \& Burns, 19 February 1968: National Archives, AAMK 869 W3074/224/b.

705 Ben White "Supplementary Report on the West Coast Settlement Reserves: A Report Commissioned by the Waitangi Tribunal for the Taranaki Claim" (Waitangi Tribunal, Wai 143, 1996) at 33-39.

706 Ngaruahine, the Trustees of Te Korowai O Ngaruahine Trust, and the Crown, Deed of Settlement of Historical Claims, 1 August 2014 at 48-49.

$707 \quad$ For other examples see Maori Purposes Act 1952, ss 8 and 12 and Maori Purposes Act 1983 , s 6.

708 Maori Purposes Act 1975, ss 18-31. See Royal Commission "Report of the Royal Commission to Inquire into the Future Use of Rangatira B and C Blocks" [1974] IV AJHR H-06. See above nn 311-316.

$709 \quad$ (7 October 1975) 402 NZPD 5257.
} 
The Maori Purposes Act 1979 returned 16 hectares of land, comprising a reserve for Tuahuriri hapū of Ngāi Tahu, to Māori control. ${ }^{710}$ The reserve was created in $1898,{ }^{711}$ with the subsequent addition of further land and a lagoon. ${ }^{712}$ The reserve was held by the Crown and managed by the Kaiapoi Reserve Board, which was comprised of a magistrate, local members of Parliament and others to be appointed by the Minister. No provision was made for representation or input from owners. This structure was consolidated in the Native Purposes Act $1931 .^{713}$

The governance structure proved difficult. Replacement of trustees was often complicated, and at times there was resistance to recommendations made by Ngāi Tūāhuriri Runanga of appointees to fill vacancies. $^{714}$ There was also confusion about who was ultimately responsible for administration and management of the reserve, with the misconception the Minister and Department were responsible. ${ }^{715}$ These difficulties prompted reconsideration of the governance arrangements. The Department invited Ngāi Tūāhuriri to consider what governance arrangements it would prefer, suggesting the Poho-o-Rawiri Marae framework as an example. ${ }^{716}$ The Runanga was unequivocal they wanted a management structure comprised of "tribal representatives of Ngai Tahu living and working in the area". 717

The land and waters were set apart as a Māori reservation to be known as "Kaiapohia $\mathrm{Pa}$ or Te $\mathrm{Pa} \mathrm{o}$ Turakautahi or Te Kohaka a Kaikai a Waro". ${ }^{718}$ The Māori Land Court was authorised to vest the reserve in trustees under the Maori Affairs Act 1953, with trustees to be nominated by the Runanga and Ngāi Tahu Māori Trust Board. ${ }^{719}$ The Kaiapoi Reserve Board ceased to exist on the Court vesting order. ${ }^{720}$ This provision was mentioned in the House by the Member for Southern Māori as respecting the wishes

\footnotetext{
$710 \quad$ Maori Purposes Act 1979, s 21.

711 Reserves, Endowments, Crown and Native Lands Exchange, Sale, Disposal, and Act 1898, s 34. See National Archives, AAMK 869 W3074/805/a (26/9).

712 Native Land Claims Adjustment and Laws Amendment Act 1901, s 40, and Native Land Amendment and Native Land Claims Adjustment Act 1924, s 21.

$713 \quad$ Native Purposes Act 1931, s 66.

714 See correspondence, 8 May 1933 to 16 July 1935: National Archives, above n 711.

715 See correspondence, 14 July 1972 to March 1978: National Archives, ABJZ 869 W4644/68 (26/9).

716 Letter, District Officer to Tau, 25 July 1978: National Archives, above n.

717 Submission, Runanga to Minister of Maori Affairs, and Letter, Ngai Tahu Maori Trust Board to Minister, 23 August 1978: National Archives, above n 715.

718 Maori Purposes Act 1979, s 21(1), observing the several names the Pā was known by: see above n.

719 Maori Purposes Act 1979, s 21(2)-(5).

720 Maori Purposes Act 1979, s 21(6). See Kaiapoi Reserve - 873A \& Waikuku Lagoon (1980) 59 South Island MB 8 (59 SI 8).
} 
of Māori, and the Member took the opportunity to emphasize the importance of Māori Purposes Bills "to the Maori community". ${ }^{721}$

This governance structure remains in place following the Ngāi Tahu Treaty settlement. ${ }^{722}$ The arrangements in respect of Kaiapoi Pā provide a further example of a developing acceptance that Māori should participate in and manage their own lands.

\section{B Mangatu Incorporation}

The governance arrangements for returning Mangatu lands to Māori proved significantly more difficult. The special regime established by the Maori Purposes Act 1947 when the land was released from the statutory control of the East Commissioner to Mangatu Incorporation was ultimately replaced by provisions reverting governance to the general Māori incorporation model.

The history of the Mangatu blocks is complex, with persistent disagreement between beneficial owners and claimants about ownership entitlements to the blocks. ${ }^{723}$ The Maori Purposes Act 1947 vested the land in a Māori incorporation comprised of the equitable owners but with key differences from the general incorporation model. Most significantly, the committee of management was to be elected by five named hapū, not by majority vote. The regime permitted the committee wider borrowing powers than other incorporations had, enabled share transfers between beneficial owners, and income was to be under the control of the committee of management, not the Maori Land Board. ${ }^{724}$ This structure was proposed by solicitors for the owners' advisory committee, who drafted the legislation. ${ }^{725}$ These provisions were described in the House as important and positive, and were viewed as trusting Māori to manage their own lands. ${ }^{726}$

Various modifications were made in 1950 at the request of the committee of management, including removing one of the named hapū from electing a member of the committee, clarification of the Māori Land Court's role, removal of Ministerial control in some areas, and permitting the Incorporation to hold

\footnotetext{
721 (19 October 1979) 426 NZPD 3676 and (4 December 1979) 427 NZPD 4425.

$722 \quad$ Ngai Tahu Claims Settlement Act 1998, s 271.

723 See Waitangi Tribunal Turanga Tangata, Turanga Whenua: The Report on the Turanga a Kiwi Claims, Vol II (Wai 814, 2004) ch 14 and Ward, above n 293, Appendix.

$724 \quad$ Maori Purposes Act 1947, ss 21-45.

725 See correspondence, 9 July 1947 to 26 September 1947: National Archives, AAMK 869 W3074/797/b (26/7/2).

726 (26 November 1947) 279 NZPD 1090-1093.
} 
more than one bank account. ${ }^{727}$ These changes were depicted as minor and were not debated in the House. ${ }^{728}$

In response to a petition seeking the right to partition interests from the Incorporation, which was not possible under the special regime, the Maori Purposes Act 1953 brought Mangatu Incorporation's governance arrangements within the general Māori incorporation model. ${ }^{729}$ Many of the advantages of Mangatu's special regime had been included within the general incorporation framework by this time, but the 1953 legislation anticipated regulations would be issued to continue the hapu election system. Due to continuing disagreement about how the committee should be elected and doubts about the validity of draft regulations, resulting in litigation and petitions to Parliament, those regulations were never finalised. ${ }^{730}$ To avoid ongoing disputes the government elected to repeal the special legislation and for the general incorporation model to apply, with the effect the committee would be elected by the majority vote. ${ }^{731}$ Responsibility was allocated to the Māori Land Court to hold a general meeting and determine the composition and election of a new committee. The changes to the regime were recognised as important and discussed in the House. ${ }^{732}$ Unfortunately, shareholder dissension and dissatisfaction was not immediately resolved, ${ }^{733}$ and some issues persisted into the Treaty of Waitangi settlements process. ${ }^{734}$

\section{The Role of Petitions: Pukepuke Tangiora Estate}

There were also provisions in Māori Purposes Acts which intervened in Māori estates, setting out new governance arrangements that were to apply. The estate of Pukepuke Tangiora in the Hawkes Bay is a prominent example. ${ }^{735}$ In both cases, legislative intervention was usually secured by way of a petition to Parliament. I focus on the Pukepuke Tangiora estate because of the number of changes within the Māori Purposes Acts and because the effect of legislative interventions has recently been considered.

\footnotetext{
727 Maori Purposes Act 1950, s 61. Letter, Committee of Management to Department, 25 January 1950: National Archives, AAMK 869 W3074/798/a (26/7/2).

728 Above n 640. See also Memorandum “Clauses for Inclusion in the Maori Purposes Bill”, 2 November 1950: National Archives, AAFD 811 W2347/107/a (CAB 266/4/1).

729 Maori Purposes Act 1953, s 23. See Maori Purposes Bill 1953 (143-2) (select committee report), explanatory note, cl 22A, and Cabinet Paper, 4 November 1953: National Archives, AAMK869 W3074/798/b (26/7/2). See Memorandum, Crown Solicitor to Secretary of Maori Affairs, 5 May 1955 and subsequent documentation: National Archives, AAMK 869 W3074/799/b (26/7/2).

$731 \quad$ Maori Purposes Act 1955, s 12.

$732 \quad$ (6 and 12 October 1955) 307 NZPD 2839, 2943-2945.

733 See documentation held by National Archives, AAMK 869 W3074/799/c (26/7/2).

$734 \quad$ See Turanga Tangata, Turanga Whenua, above $\mathrm{n} 723$.

735 Another example is the Hemi Matenga Trust: Native Purposes Act 1941, s 12.
} 
The need for legislative provisions originated from unforeseen limitations of Pukepuke Tangiora's will, which dealt with her very valuable estate. Most of the estate was to be held on trust until twenty years after the death of Pukepuke Tangiora's surviving grandchildren, the children of her son Te Akonga, at which time the residuary estate was to be divided between the descendants of these grandchildren. Te Akonga and the grandchildren had been left a joint life interest in the homestead property, together with a small number of other beneficiaries. The homestead was not permitted to be leased, sold or mortgaged during the lifetime of Te Akonga and the grandchildren, and this prohibition extended to much of the land held in the estate. Te Akonga was also gifted an annuity of $£ 1000$ during his lifetime, with smaller annuities in favour of the grandchildren once they reached stipulated ages. Te Akonga was appointed as an executor and trustee, along with Pukepuke Tangiora's solicitor. ${ }^{736}$

Te Akonga died only months after his mother, and his dependent family were left without his income from the estate. The trustees of the will secured increased annuities for the grandchildren, ${ }^{737}$ but a petition was subsequently presented to Parliament by the grandchildren claiming the terms of the will and codicil caused an injustice, alleging their grandmother had not understood either document. ${ }^{738}$

The petitioners made a general request for a legislative remedy in respect of the will and codicil, which was opposed by trustees. ${ }^{739}$ The Committee recommended the petition for favourable consideration with specific directions the beneficiaries be represented on the trust, that legislation vary the will to provide for the housing and other needs of the beneficiaries, and the Native Trustee be involved in the administration of the trust. ${ }^{740}$ Provision was added to the Native Purposes Bill 1943 while it was before the Committee and it was briefly commented on in the House. ${ }^{71}$

The modifications to the terms of the estate were extensive, providing legislative remedies not available within the general legislative framework. ${ }^{742}$ The Governor-General was empowered to appoint and remove trustees and the Native Trustee was authorised to be appointed as one of the trustees. There was no express provision requiring beneficiaries to be appointed as trustees, but the Governor-General's powers were viewed as the means by which the government could intervene, if necessary, to secure Will, 2 April 1931 and Codicil, 31 October 1936: National Archives, AEBE 18507 LE1/1210 (1942/8).

737 Affidavit of Eric Volkman Simpson dated 25 September 1940: National Archives, above $\mathrm{n}$.

738 Petition No 52/1942: National Archives, above n 736.

739 Minute Book of the Native Affairs Committee (1943), 24 and 25 June 1943: National Archives, AEBE 18507 LE1 $1224(1943 / 13)$.

740 Native Affairs Committee "Reports of the Native Affairs Committee" [1943] AJHR I3 at 3.

$741 \quad$ Native Purposes Bill 1943 (29-2) (select committee report), explanatory note, cl 15B and (25 August 1943) 263 NZPD at 1067-1068.

$742 \quad$ Native Purposes Act 1943, s 17.
} 
appointments of beneficial owners as trustees. ${ }^{743}$ Unfortunately those powers were dependent on political favour and failed to secure the intended result. ${ }^{744}$

The legislation permitted any land to be transferred to Te Akonga's children for residential building sites, and the homestead property was permitted to be transferred to any beneficiary with a life interest in the homestead. ${ }^{745}$ An application to partition the homestead by one of the life tenants was effected under this provision with the agreement of the family, ${ }^{746}$ and more recently the provision was relied on to grant an occupation order in favour of a beneficiary. ${ }^{747}$ Other measures to release income were implemented and the date of distribution was shortened. The provision did not further alter the annuities payable to the grandchildren, but specified the method of calculation to ensure annuitants received the maximum benefit. Trustees were also permitted to lease lands. ${ }^{748}$

In subsequent years other changes were made to the estate, usually following petitions to Parliament by Te Akonga's children who sought access to estate funds for their support, educational needs, farming purposes, and to carry out maintenance or renovations to property that were not otherwise permitted by the original terms of the will or legislative amendments. ${ }^{749}$ These provisions passed through the House with little comment.

In 2005 a petition was presented to Parliament by the last two surviving grandchildren of Pukepuke Tangiora requesting the trust "be revived in its original form" prior to the 1943 legislative provisions. ${ }^{750}$ The petition reflected dissatisfaction with a number of aspects of the trust's administration including the lack of descendants appointed as trustees, with only one descendant appointed, and it sought to preserve the remaining estate intact. ${ }^{751}$ The Committee recommended the government promote a Māori Purposes

\footnotetext{
$743 \quad$ NZPD, above n 741.

744 For example, see Letter, Maori Trustee to Associate Minister of Maori Affairs, 26 March 1958: National Archives, AAMK 869 W3074/754/b (24/2/4).

745 Native Purposes Act 1943, s 17(7). There was later uncertainty about the meaning of the subsection: Memorandum of Office Solicitor, 30 January 1963: National Archives, above n.

746 Kakiraawa 2B1, 2B2F and 2B2M (1945) 86 Napier MB 135-141 (86 NA 135).

747 Baker - Waipuka 2S2 Block (2016) 56 Takitimu MB 49 (56 TKT 49).

$748 \quad$ Native Purposes Act 1943, s 17(12).

749 Native Purposes Act 1946, s 16, Maori Purposes Act 1948, s 19, Maori Purposes Act 1951, s 37, Maori Purposes Act 1963, s 19 and Maori Purposes Act 1976, s 26. See petitions and documentation: National Archives, AAMK 869 W3074/754/a to c (24/2/4).

$750 \quad$ Petition 105/2005: National Archives, ABGX 16127 W5552/229 (2005/150).

751 Statement of Hariata Te Ruru Te Akonga Mohi Baker, 16 September 2007: National Archives, above n.
} 
Bill to reinstate a prohibition on alienation and provide a more appropriate trustee appointment process. $^{752}$

Further consultation with beneficiaries indicated diverse views about future management of the estate and whether distribution should be delayed. ${ }^{753}$ However, the date of distribution was extended for five years to enable the beneficiaries to make decisions about the future of the estate after the death of the last grandchild, and the Māori Land Court was empowered to determine the appointment of trustees. ${ }^{754}$

The intervention of the Crown in Pukepuke Tangiora's estate was described in the House as an injustice and as reflecting the paternalism of the state. ${ }^{755}$ The situation was more complex than this position acknowledges. The legislative regime was a response to the petitioning of Te Akonga's children for access to funds and property, which could be interpreted as respecting Māori self-determination at the time and secured advantages to beneficiaries not available within the terms of the estate. The process by which the Governor-General appointed trustees was paternalistic by modern standards and was an uncertain means of ensuring beneficial owners would be appointed as trustees. It was disappointing the provision was not used as intended to ensure a family member acted as a trustee, as Pukepuke Tangiora's will did, but it is difficult to conceive of the whole regime as an injustice.

\section{Conclusions}

The special governance provisions in Māori Purposes Acts demonstrate a degree of experimentation with governance frameworks, such as trusts and boards, provisions which were contained in the legislation prior to incorporation of these concepts in general legal frameworks. Many examples of governance arrangements were the legacy of disputes with the Crown or problematic situations, and as such these special arrangements developed on an ad hoc basis, usually at the instigation of Māori.

Some governance arrangements were a hybrid of elements drawn from existing legal frameworks. In other cases, special provisions built on the general framework or created exceptions to that framework in an attempt to facilitate arrangements better suited to Māori needs. The fact Māori sought special arrangements highlights the limitations of general governance models to deal with Māori land, which were often highly prescriptive and built on Western ideas of governance. ${ }^{756}$ There are various examples

\footnotetext{
752 Māori Affairs Committee "Report of the Māori Affairs Committee: Petition 2005/150 of Hariata Baker" [2005-2008] 14 AJHR 809 at 4-5.

753 Māori Affairs Committee "Report of the Māori Affairs Committee: Maori Purposes Bill (234-1)" [2008-2011] 15 AJHR 1211 at 1212-1213.

$754 \quad$ See Stone - Pukepuke Tangiora Estate (2013) 26 Tākitimu MB 64 (26 TKT 64).

755 (16 November 2010) 668 NZPD 15367 and (13 September 2011) 675 NZPD at 21252-21253 and 21260.

$756 \quad$ See Jones, above $\mathrm{n} 80$, at 123.
} 
of special arrangements transitioning to governance structures under general legislation once general frameworks became available or more attractive with the easing of rigid and restrictive provisions.

Many of these special governance arrangements, and amendments to original regimes, facilitated Māori control over their lands and Māori autonomy, with the gradual removal of Crown involvement. Among the examples considered, there are regimes which have stood the test of time, such as the exclusive regime protecting the Lake Rotoaira fishery and Wi Pere Trust, which has recently been celebrated as a leading example of what Māori can achieve. Other arrangements have not been successful for various reasons, including the provisions in respect of Parininihi ki Waitotara Reserve.

Despite the fact most of these governance structures have endured in one form or another, this has not precluded claims within the modern Treaty of Waitangi settlements process. It is not possible to conclude whether these governance arrangements have fully satisfied Māori aspirations for self-determination and control of their lands within the scope of this project, but these arrangements provide evidence of the potential benefits of recognising diversity in governance arrangements. ${ }^{757}$

Legislative provisions enacting special governance arrangements were often characterised as minor or as being of a "washing-up" nature in earlier decades and were not debated in the House or received minimal consideration. This occurred despite provisions altering property interests in land and voting rights. In later decades these provisions were more likely to be recognised as important as they permitted a degree of Māori self-determination, which was particularly notable in the enactment of provisions modernising Wi Pere Trust's special governance regime in 2017. In most cases, there was limited awareness of the reasons for special governance arrangements being passed into law by the House, and an absence of discussion about how those provisions may have respected Crown obligations under the Treaty of Waitangi. 


\section{Chapter 9: Conclusions}

\section{I “Washing-up” and Legislative Process}

Māori Purposes Acts were a regular feature on the legislative calendar between 1931 and 1985 with a Māori Purposes Act passed into law almost every year. The legislation contained a combination of government policy provisions and provisions dealing with essentially private matters. Provisions dealt with the administration and machinery of government, made amendments to existing laws and introduced new policy, created exceptions to general legal frameworks including special governance structures, and remedial provisions responded to petitions and claims by Māori. From 1985 Māori Purposes Acts significantly decreased in scope and frequency, although the Māori Purposes Act 2017 defies that trend. Many provisions of Māori Purposes Acts remain in force, usually those establishing special governance arrangements.

Despite being a legislative device that was so frequently employed, Māori Purposes Acts have not attracted much attention within the House of Representatives or in academic literature. The legislation was commonly described as being of a "washing-up" nature, which was a non-technical and informal characterisation that indicated established legislative procedure and clear expectations as to the content of Māori Purposes Bills before the House.

The "washing-up" characterisation signaled a bill was an end of session measure that was expected to contain minor and uncontroversial machinery, technical and administrative provisions collated during the year. It was also expected that Māori Purposes Bills would contain remedial and claims provisions, which reflected the origins of term "washing-up" in legislation dealing solely with Māori claims. Māori Purposes Bills were expected to contain provisions that were related to Māori affairs, a requirement that was observed. The legislation was not expected to contain controversial or significant new policy provisions.

The "washing-up" characterisation was only accurate if the content of the legislation fitted within these parameters, which many Bills and provisions did not. Some Māori Purposes Acts were notable for their wholesale deviation from the "washing-up" concept, which occurred when new, large-scale policies were contained within the legislation. In such cases no attempt was made to disguise the true nature of the legislation, and at times more discrete policy changes were also recognised as important. However, it was common for important provisions to be dismissed as being of the usual tidying-up or "washing-up" kind. This characterisation can be challenged on the basis of the effect of many legislative provisions. Provisions validated transactions that were otherwise not legally permitted, and altered legal and property rights including changing land status, interests in property, or the nature of property ownership. 
Provisions authorised Court applications, hearings and investigations not available within the general legal framework, reversed Court orders and changed policy to circumvent Court decisions. The legislation also created exceptions to the general legislative framework, including establishing special governance arrangements not provided for at general law.

At worst, the mischaracterisation was a deliberate tactic to ensure important provisions did not attract attention during the legislative process or it reflected a colonial mentality of officials and Members of the House, who did not understand or value the work that Māori Purposes Acts performed within the legal system. The term "washing-up" has not been used in recent years to describe the legislation, in part reflecting a modern awareness of the significance of the work of Māori Purposes Acts.

The effect of the "washing-up" mischaracterisation on the legislative process is clear. Little attention was given to Māori Purposes Bills in the House and passage of the legislation was usually swift and noncontroversial even when timeframes were short and important provisions were contained in the legislation. Parliament appeared content to allow the Committee, which often included the Native Minister or Minister of Māori Affairs, to assess and manage the content of the legislation. The Committee was able to make improvements to the legislation, but was only occasionally able to alter government policy.

Many Māori Purposes Acts were passed under urgency, a state of affairs the "washing-up" misnomer served. Only a small number of fractious debates from the 1970s onwards punctuated the generally smooth process, with concerns centred around short timeframes to consider the Bills, which placed pressure on the Committee and constrained public consultation with Māori. This was unsatisfactory in the context of complex histories behind remedial provisions and constantly shifting government policies. Dealing with provisions in isolation from the wider policy context and with limited historical background meant Members of the House could not have appreciated the significance or implications of many provisions in Māori Purposes Bills.

The hurried legislative process applied regardless of the range of provisions contained in Bills, which sometimes resulted in drafting errors that had to be rectified, and processes or policy provisions that proved unworkable or insufficient and were revisited. This hurried process has not been evident in the passage of the most recent Māori Purposes Acts.

Although there is no certainty more debate would have improved policy and remedial outcomes for Māori, quick legislative passage for the majority of Māori Purposes Acts meant limited opportunity for airing and fully considering the detail and context of issues and problems that necessitated annual legislation. There was minimal reflection about the need for constant legislation to expand and maintain 
the legislative framework, to fix Crown errors and to ameliorate unfair outcomes or consequences for Māori. Although Māori Purposes Acts were intended to contain "special provisions", the frequency of the legislation indicated a different reality.

\section{The Work of Māori Purposes Acts}

Māori Purposes legislation fulfilled an essential role within New Zealand's legal system, which Karl Llewellyn's law-jobs theory draws attention to. Focusing on the functions Māori Purposes Acts performed within the legal system makes sense of provisions that might otherwise appear too diverse to reconcile.

$A$

Government Machinery, Amendments and Policy

The legislation undoubtedly contained minor, administrative and machinery or technical provisions that fell within the concept of "washing-up". Llewellyn's theory highlights the essential purpose such provisions fulfilled in maintaining and improving the administration and functioning of New Zealand's legal system. This is evidenced by necessary adjustments and extensions to the jurisdiction of the Māori Land Court and role of the Māori Trustee. Minor amendments and non-controversial adjustments of existing government policy characterised as "washing-up" provisions could not be dismissed as unimportant either, given the work such provisions performed in adjusting legal frameworks and the impact of even minor changes on the lives of Māori.

Māori Purposes Acts also enacted amendments and policy changes that were less innocuous and did not fit within the "washing-up" characterisation. Amendments and policy changes filled gaps in the general legislative framework and extended existing policy, often for the purpose of rectifying perceived problems. Llewellyn's theory focuses attention on the lack of clear policy direction in Māori affairs, evidenced by constant changes and repairs to legal frameworks. In turn, this draws attention to the illfit of the general legislative regime with Māori needs; a system that was failing Māori and reflected the perils of laws that did not accommodate custom. A degree of experimentation with policy provisions is also revealed, provisions that were either repealed in time or developed further and adopted into the general legislative regime.

In the sense that some policy changes in Māori Purposes Acts attempted to ensure Māori had the same rights as Europeans or respected Māori identity and customary practices, it could be argued the legislation provided Māori with some measure of justice. For the most part, Māori Purposes Acts made frequent and sometimes inconsistent changes to the legal system without principled debate or analysis, and without substantive changes to the legislative framework, positive gains for Māori were limited. Many 
changes were not made for the benefit of Māori and when positive changes were made, such as provisions recognising Māori customary practices, further changes in policy direction often undermined or reversed positive steps forward.

\section{B Special Governance Arrangements}

The special governance provisions in Māori Purposes Acts tell a similar story as the policy and amendment provisions, as these provisions also reveal the poor fit of the general legislative regime for Māori needs. The fact Māori sought special governance arrangements indicated dissatisfaction with the restrictions of the general legislative framework, which did not meet Māori aspirations for control of their own assets or permit governance regimes reflecting Māori perspectives. These special governance provisions created exceptions to the general legislative regime in an unplanned fashion, and although such provisions might be expected to fall within Llewellyn's second law-job, many provisions had origins in, or formed part of, responses to "trouble-cases". These provisions reveal a degree of experimentation with governance structures, the results of which were sometimes adopted into the general legislative regime. Many special governance arrangements have stood the test of time.

To the extent that special governance structures responded to or provided for Māori wishes, tikanga or self-determination these provisions could be viewed as respecting the Crown's obligations under the Treaty of Waitangi, but this was rarely recognised at the time. The recent celebration of the success of Wi Pere Trust's special legislative regime reflects a modern awareness of the value of special governance provisions and respect for Māori self-determination.

\section{Petitions and Legislative Responses}

Māori Purposes Acts facilitated a systematic process in response to petitions by Māori or in respect of Māori matters that were supported by the Committee and the House. Māori relied heavily on the petitions process for many decades to raise grievances and pursue remedies in the absence of legal rights and remedies for Crown errors or recourse for legislative regimes that did not accommodate Māori needs.

The petitions process had serious limitations and legislative responses were often minimal, more often providing for further procedural steps than delivering determinate and tangible remedies. Some of the examples considered in the research illustrate the capacity of the process to deliver quick and effective outcomes for Māori, but equally, the process could be slow and effect injustice. The process and outcomes relied on a political favour and were based on subjective notions of equity and fairness in a period where colonial attitudes prevailed, resulting in legislative remedies that were unpredictable and 
inconsistent. This was far from an ideal mechanism for dealing with Māori problems and grievances for the benefit of Māori and New Zealand society, or as a means for delivering justice.

The systematic process facilitated by Māori Purposes Acts was unfairly characterised as "washing-up" or insignificant, which ignores the fact it was the only avenue for justice available to Māori, and the number of provisions responding to Māori petitions cannot be interpreted as isolated responses to special situations or unique problems. This process, and legislative responses to Māori grievances, were attempts to resolve disputes to preserve New Zealand society from the effects of unhealed breaches, reflecting Llewellyn's crucial first law-job. Many legislative responses authorised further procedural steps within the legal framework such as hearings and investigations, and in doing so, allocated and extended judicial authority for the purpose of dispute resolution, falling within Llewellyn's third lawjob.

The fact Māori Purposes Acts did not deliver reliable outcomes and many provisions fell short of justice offers further evidence of a legal system that was failing Māori. It would be valuable for research to examine further decisions of the Māori Land Court in respect of petitions, particularly in the early 1900s, encompassing comparative analysis with the development of the law of equity in New Zealand.

\section{D $\quad$ Settlements and Remedial Provisions}

Settlements and other remedial provisions in Māori Purposes Acts responded to long-standing Māori grievances and claims against the Crown, which was recognised as necessary for the purpose of enabling New Zealand society to move forward. However, the limited nature of relief provided to Māori undermined any prospect that settlements would permanently resolve the claims addressed.

Legislative settlements were usually limited to compensation that did not meet Māori expectations instead of returning land to Māori, even when it remained within Crown control, and failed to restore Māori to their previous position. Similar difficulties plagued remedial provisions that were not expressed as settlements, which often resolved problems from the Crown's perspective, leaving Māori to recover compensation under the Public Works Act rather than returning land to Māori. In this sense legislative provisions in Māori Purposes Acts fell short of fulfilling Llewellyn's law-job of disposing of troublecases, and many examples considered reveal the limitations of the Crown acting as the arbitrator of justice when it was the wrongdoer.

Andrew Sharp's reparative justice framework raises the difficulty of being able to agree on wrongs in a bicultural society. Many settlement and remedial provisions in Māori Purposes Acts suggest the point of tension was caused by the Crown's reluctance to account for acknowledged wrongs or provide full 
compensation. With no legal remedies to call upon, Māori took what they could get. The revisiting of claims and grievances addressed by the Māori Purposes Acts within the modern Treaty of Waitangi settlements process evidences the failure of those provisions to meet the criteria for justice and restore balance between Māori and the Crown.

\section{Final Observations}

Māori Purposes Acts provided the Crown with a vehicle to patch-up and extend government policies affecting Māori, address administrative problems as they arose each year, create exceptions to general legislative regimes, and resolve issues largely caused by Crown errors and omissions, without drawing unwanted attention to the situations at hand.

The reactive and problem-solving nature of many provisions in Māori Purposes Acts suggests the legislation was, in Llewellyn's words, the "garage-repair work" on a faltering and deficient legal order. Llewellyn's theory raises the question of whose interests Māori Purposes Acts were intended to serve. Many provisions were considered by the Crown to benefit particular Māori and Māori society, which is a reasonable interpretation in respect of provisions that were in fact beneficial for Māori. Provisions that reversed policies that were positive for Māori, and endeavoured to eliminate long-standing Māori grievances without restoring Māori to their original position, can only be explained in the context of a broader societal group. In such cases, provisions in Māori Purposes Acts were not enacted in the best interests of Māori, but served the interests of the Crown and wider New Zealand society, at least in the short-term.

Legislative responses to the problems and claims raised by Māori were formulated in the absence of well-defined or consistent Crown policy and with an undefined sense of moral obligation to Māori. Although many provisions could in hindsight be characterised as reflecting Crown obligations under the Treaty of Waitangi, the contemporaneous evidence does not indicate conscious or consistent reference to the Treaty of Waitangi as the motivation behind legislative responses, which tended to be pragmatic rather than principled.

Māori Purposes Acts did not consistently deliver what might be considered justice for Māori, but that does not detract from the significance of many provisions in the legislation or the role the legislation fulfilled within New Zealand's legal system. Māori Purposes Acts were regularly dismissed as "washing-up" for many decades based on perceptions at the time, indicating it did not warrant detailed consideration by the House of Representatives. Considered examination of the legislation reveals the importance of the work it carried out, which included many important steps towards justice for Māori. 
Bibliography

A Case Law

Application by Minister of Lands - Owhaoko Gift Blocks (1975) 54 Tokaanu MB 108 (54 ATK 108).

Baker - Waipuka 2S2 Block (2016) 56 Takitimu MB 49 (56 TKT 49).

Estate Teo Tipene (1943) 6 Wellington Appellate MB 213a (6 APWN 213a).

Hereaka $v$ Prichard [1967] NZLR 18 (CA).

Hereaka $v$ Prichard and Others [1965] NZLR 302 (SC).

Kaiapoi Reserve - 873A \& Waikuku Lagoon (1980) 59 South Island MB 8 (59 SI 8).

Kaiti 38 and 39 (1927) 56 Gisborne MB 54 (56 GIS 54).

Kakiraawa 2B1, 2B2F and 2B2M (1945) 86 Napier MB 135-141 (86 NA 135).

Paki v Attorney-General (No 2) [2014] NZSC 118; [2015] 1 NZLR 67 (SC).

Re Application by Beare and Perry for Mining Area in the Arahura River (1900) 2 GLR 242 (SC).

Re Foster's Caveat (1907) 26 NZLR 890 (SC).

Re Turuhira Tuhiwai [1936] GLR 382 (SC).

Sadlier v Fitzsimmons \& Ors - Anaura Inc (2006) 32 Tairāwhiti Appellate MB 342 (32 APGS 342).

Stone - Pukepuke Tangiora Estate (2013) 26 Tākitimu MB 64 (26 TKT 64).

Tokerau District Maori Land Board v Leach CA 2334, 14 July 1943.

Teo Tipene (Deceased) (1937) 30 Wellington MB 17 (30 WN 17).

Teo Tipene (Deceased) (1937) 7A Wellington Appellate MB 255 (7A APWN 255).

Teo Tipene, deceased (1943) 34 Wellington MB 327 (34 WN 327).

Tipene v Tutua Teone [1937] NZLR 1098 (CA).

Tutua Teone v Jones [1936] NZLR 494 (CA).

Tutua Teone v Tipene [1936] NZLR 642 (SC).

Van Den Berg v Giles [1979] 2 NZLR 111 (SC).

Whaiti-Kuranui 5C3, 5D1C, 5D1B and 5D2 (1945) 94 Rotorua MB 217 (94 ROT 217).

Whakawehi 113 (1934) 59 Otaki MB 253 (59 OTI 253).

Wi Pere Trust (1937) 64 Gisborne MB 104 (64 GIS 104).

Wi Parata v Bishop of Wellington (1877) 3 NZ Jur (NS) SC 72; (1877) 1 NZLRLC 14 (SC).

B Legislation and Regulations

Adoption of Children Act 1895.

Companies Act 1955.

Companies Act 1993.

Crown Suits Act 1908.

Crown Suits Amendment Act 1910. 
Crown Proceedings Act 1950.

Fisheries Act 1908.

Infants Act 1908.

Law Reform (Miscellaneous Provisions) Bill (No 5) 1996 (148-2).

Limitation Act 1950.

Maori Affairs Act 1953.

Maori Affairs Amendment Acts 1962, 1967, 1974 and 1987.

Maori Affairs Amendment Bill 1985 (55-2A).

Maori Affairs Bill 1987 (No 124-1).

Maori Affairs Restructuring Acts 1989 and 1996.

Maori Community Development Amendment Act 1996.

Maori Land Amendment Act 1952.

Maori Land Amendment and Maori Land Claims Adjustment Act 1996.

Maori Land Claims Adjustment and Laws Amendment Acts 1904, 1906 and 1907.

Maori Land Laws Amendment Acts 1903 and 1908.

Māori Purposes Acts 1947-2017.

Māori Purposes Bills 1947-2017.

Maori Purposes (Wi Pere Trust) Act 1991.

Maori Reserved Land Act 1955.

Maori Reserved Land Amendment Bill (No 2) 1998 (103-1).

Maori Social and Economic Advancement Act 1945.

Maori Trustee Act 1953.

Maori Trustee Amendment Act 1996.

Maori Trust Boards Act 1955.

Maori Trust Boards Amendment Act 1996.

Native Land Act 1909.

Native Land Act 1931.

Native Land Amendment Acts 1912, 1913, 1914, 1932 and 1936.

Native Land Amendment and Native Land Claims Adjustment Acts 1915-1930.

Native Land Claims Adjustment Acts 1910, 1911, 1913 and 1914.

Native Land Claims Adjustment and Laws Amendment Act 1901.

Native Land Laws Amendment Act 1897.

Native Purposes Acts 1931-1946.

Native Purposes Bills 1931-1946.

New Zealand Bill of Rights Act 1990.

Ngai Tahu Claim Settlement Act 1944.

Ngai Tahu Claims Settlement Act 1998. 
Ngāti Kōata, Ngāti Rārua, Ngāti Tama ki Te Tau Ihu, and Te Ātiawa O Te Waka-a-Māui Claims Settlement Act 2014.

Property Law Amendment Act 1963.

Public Trust Office Amendment Act 1971.

Rehabilitation Act Repeal Act 1991.

Reserves and Other Lands Disposal Acts 1931-2017.

Reserves, Endowments, Crown and Native Lands Exchange, Sale, Disposal, and Act 1898.

Rotoaira Trout Fishing Regulations 1959.

Servicemen's Settlement and Land Sales Act 1943.

Statutes Amendment Acts 1936-1951.

Statutes Amendment Bills 1931-2017.

Taranaki Maori Claims Settlement Act 1944.

Te Ture Whenua Maori Act 1993.

Te Ture Whenua Maori Amendment Act 1996.

Te Ture Whenua Maori Amendment Bill 1998 (336-1).

Trustee Act 1956.

Waikato-Maniapoto Maori Claims Settlement Act 1946.

C Supplementary Order Papers

Supplementary Order Paper 1966 (30) Maori Purposes Bill 1966 (114-1).

Supplementary Order Paper 1976 (28) Maori Purposes Bill 1976 (100-1).

Supplementary Order Paper 1976 (41) Maori Purposes Bill 1976 (100-1).

D Books and Chapters in Books

Atholl Anderson, Judith Binney and Aroha Harris Tangata Whenua: A History (Bridget Williams Books, Wellington, 2015).

Angela Ballara "The Innocence of History? The case of the 'Morioris' of Te Wai Pounamu a.k.a. the 'Waitaha Nation'" in Andrew Sharp and PG McHugh (eds) Histories, Power and Loss: Uses of the Past - A New Zealand Commentary (Bridget Williams Books, Wellington, 2001).

Maria Bargh (ed) Māori and Parliament: Diverse Strategies and Compromises (Huia Publishers, Wellington, 2010).

Michael Belgrave Historical Frictions: Maori Claims \& Reinvented Histories (Auckland University Press, Auckland, 2005). 
Michael Belgrave, Merata Kawharu and David Williams (eds) Waitangi Revisited: Perspectives on the Treaty of Waitangi (Oxford University Press, South Melbourne, 2005).

Richard Boast Buying the Land, Selling the Land: Governments and Maori Land in the North Island 1865-1921 (Victoria University Press, Wellington, 2008).

Richard Boast, Andrew Erueti, Doug McPhail and Norman F Smith Māori Land Law (2 ${ }^{\text {nd }}$ ed, Lexis Nexis, Wellington, 2004).

FM (Jock) Brookfield Waitangi \& Indigenous Rights: Revolution, Law \& Legitimation (2 ${ }^{\text {nd }}$ ed, Auckland University Press, Auckland, 2006).

GV Butterworth and HR Young Maori Affairs: A Department and the People Who Made It (Government Printer, Wellington, 1990).

RI Carter Burrows and Carter Statute Law in New Zealand ( $5^{\text {th }}$ ed, Lexis Nexis, Wellington, 2015)

Charles Cato Restitution in Australia and New Zealand (Cavendish Publishing, Sydney, 1997).

John W Creswell Research Design: Qualitative, Quantitative, and Mixed Methods Approaches $\left(4^{\text {th }}\right.$ ed, Sage Publications, California, 2014).

Mason Durie Te Mana, Te Kāwanatanga: The Politics of Māori Self-Determination (Oxford University Press, Auckland, 1998).

Lee Epstein and Andrew D Martin An Introduction to Empirical Legal Research (Oxford University Press, Oxford, 2014).

Harry C Evison The Ngai Tahu Deeds: A Window on New Zealand History (Canterbury University Press, Christchurch, 2006).

Mark Francis "Writings on Colonial New Zealand: Nationalism and Intentionality" in Andrew Sharp and PG McHugh (eds) Histories, Power and Loss: Uses of the Past-A New Zealand Commentary (Bridget Williams Books, Wellington, 2001).

Claudia Geiringer, Polly Higbee and Elizabeth McLeay What's the Hurry? Urgency in the New Zealand Legislative Process 1987-2010 (Victoria University Press, Wellington, 2011). 
Margaret Greville, Scott Davidson and Richard Scragg Legal Research and Writing in New Zealand (3 ${ }^{\text {rd }}$ ed, Lexis Nexis, Wellington, 2007).

Mary Harris and David Wilson (eds) McGee Parliamentary Practice in New Zealand (4 ${ }^{\text {th }}$ ed, Oratia Books, Auckland, 2017).

HLA Hart The Concept of Law ( $3^{\text {rd }}$ ed, Oxford University Press, Oxford, 2012).

Richard S Hill State Authority, Indigenous Autonomy: Crown-Maori Relations in New Zealand/Aoteoroa 1900-1950 (Victoria University Press, Wellington, 2004).

Richard S Hill Maori and the State: Crown-Maori Relations in New Zealand/Aoteoroa, 1950-2000 (Victoria University Press, Wellington, 2009).

M Jackson "Colonisation as Myth-Making: A Case Study in Aotearoa" in Greymorning S (ed) A Will to Survive: Indigenous Essays on the Politics of Culture, Language and Identity (McGraw Hill, New York, 2004).

Carwyn Jones New Treaty, New Tradition: Reconciling New Zealand and Māori Law (Victoria University Press, Wellington, 2016).

Philip A Joseph Constitutional and Administrative Law in New Zealand ( $4^{\text {th }}$ ed, Brookers, Wellington, 2014).

IH Kawharu (ed) Waitangi: Maori \& Pakeha Perspectives of the Treaty of Waitangi (Oxford University Press, Auckland, 1989).

Harshan Kumarasingham Onward with Executive Power: Lessons from New Zealand 1947-57 (Institute of Policy Studies, Victoria University of Wellington, Wellington, 2010).

Marett Leiboff and Mark Thomas Legal Theories: Contexts and Practices $\left(2^{\text {nd }}\right.$ ed, Thomson Reuters, Sydney, 2014).

Karl N Llewellyn Jurisprudence: Realism in Theory and Practice (University of Chicago Press, Chicago, 1962). 
KN Llewellyn and E Adamson Hobel The Cheyenne Way: Conflict and Case Law in Primitive Jurisprudence (University of Oklahoma Press, Oklahoma, 1941).

Ryan Malone Rebalancing the Constitution: The Challenge of Government Law-making under MMP (Institute of Policy Studies, Victoria University of Wellington, Wellington, 2008).

Mike McConville and Wing Hong Chui (eds) Research Methods for Law (Edinburgh University Press, Edinburgh, 2007).

David McGee "The Legislative Process and the Courts" in Philip A Joseph (ed) Essays on the Constitution (Brookers, Wellington, 1995).

PG McHugh Aboriginal Societies and the Common Law: A History of Sovereignty, Status, and SelfDetermination (Oxford University Press, Oxford, 2004).

PG McHugh "Legal Reasoning and the Treaty of Waitangi: Orthodox and Radical Approaches" in Graham Oddie and Roy W Perrett (eds) Justice, Ethics, and New Zealand Society (Oxford University Press, Auckland, 1992).

Geoff McLay, Christopher Murray and Jonathan Orpin New Zealand Law Style Guide (2 $2^{\text {nd }}$ ed, Thomson Reuters, Wellington, 2011).

Elizabeth McLeay The Cabinet \& Political Power in New Zealand (Oxford University Press, Auckland, 1995).

Alan McRobie "The Politics of Volatility" in Geoffrey W Rice (ed) The Oxford History of New Zealand $\left(2^{\text {nd }}\right.$ ed, Oxford University Press, Auckland, 1992).

John E Martin The House: New Zealand's House of Representatives 1854-2004 (Dunmore Press, Palmerston North, 2004).

Ani Mikaere Colonising Myths - Maori Realities: He Rukuruku Whakaaro (Huia Publishers, Wellington, 2011).

Hilary and John Mitchell Te Tau Ihu O Te Waka, A History of Maori of Nelson and Marlborough, Vol II: Te Ara Hou - The New Society (Huia Publishers, Wellington, 2007). 
Claudia Orange The Treaty of Waitangi (Allen \& Unwin, Wellington, 1987).

Vincent O'Malley and David Armstrong The Beating Heart: A political and socio-economic history of Te Arawa (Huia Publishers, Wellington, 2008).

Geoffrey Palmer New Zealand's Constitution in Crisis: Reforming our Political System (John McIndoe, Dunedin, 1992).

Geoffrey Palmer Unbridled Power: An Interpretation of New Zealand's Constitution and Government ( $2^{\text {nd }}$ ed, Oxford University Press, Auckland, 1987).

Geoffrey Palmer and Matthew Palmer Bridled Power: New Zealand Government under MMP $\left(3^{\text {rd }}\right.$ ed, Oxford University Press, Auckland, 1997).

Matthew SR Palmer The Treaty of Waitangi in New Zealand's Law and Constitution (Victoria University Press, Wellington, 2008).

JE Penner and E Melissaris McCoubrey \& White's Textbook on Jurisprudence $\left(5^{\text {th }}\right.$ ed, Oxford University Press, Oxford, 2012).

Joseph Anaru Te Kani Pere Wiremu Pere: The Life and Times of a Maori Leader, 1837-1915 (Oratia Media, Auckland, 2010).

Andrew Sharp Justice and the Māori: The Philosophy and Practice of Māori Claims in New Zealand since the 1970s ( $2^{\text {nd }}$ ed, Oxford University Press, Auckland, 1997).

Andrew Sharp and PG McHugh (eds) Histories, Power and Loss: Uses of the Past - A New Zealand Commentary (Bridget Williams Books, Wellington, 2001).

Peter Spiller, Jeremy Finn and Richard Boast A New Zealand Legal History (2 ${ }^{\text {nd }}$ ed, Brookers, Wellington, 2001).

George Tanner "Confronting the Process of Statute-Making" in Rick Bigwood (ed) The Statute: Making and Meaning (Lexis Nexis, Wellington, 2004).

William Twining General Jurisprudence: Understanding Law from a Global Perspective (Cambridge University Press, Cambridge, 2009). 
William Twining Karl Llewellyn and the Realist Movement $\left(2^{\text {nd }}\right.$ ed, Cambridge University Press, Cambridge, 2012).

Raymond Wacks Understanding Jurisprudence: An Introduction to Legal Theory $\left(4^{\text {th }}\right.$ ed, Oxford University Press, Oxford, 2015).

Jeremy Waldron The Dignity of Legislation (Cambridge University Press, Cambridge, 1999).

Alan Ward A Show of Justice: Racial Amalgamation in Nineteenth Century New Zealand (Auckland University Press, Auckland, 1973).

Alan Ward An unsettled history: Treaty claims in New Zealand today (Bridget Williams Books, Wellington, 1999).

Nicola R Wheen and Janine Hayward (eds) Treaty of Waitangi Settlements (Bridget Williams Books, Wellington, 2012).

David V Williams A Simple Nullity? The Wi Parata Case in New Zealand law \& history (Auckland University Press, Auckland, 2011).

David V Williams Te Kooti Tango Whenua: The Native Land Court 1864-1909 (Huia Publishers, Wellington, 1999).

Joe Williams "The Status and Nature of the Treaty of Waitangi” in Caroline Morris, Jonathan Boston and Petra Butler (eds) Reconstituting the Constitution (Springer, Berlin, 2011).

E Commentaries

Laws of New Zealand Administration of Estates; Husband and Wife; Maori Affairs; Maori Land (online ed).

F Journal Articles

Mark Bennett and Nicole Roughan "Rebus Sic Stantibus and the Treaty of Waitangi” (2006) 37 VUWLR 505.

R Boast "Recognising Multi-Textualism: Rethinking New Zealand's Legal History" (2006) 37 VUWLR 547. 
RP Boast "Treaties Nobody Counted On” (2011) 42 VUWLR 653.

JF Burrows and PA Joseph "Parliamentary Law-Making” [1990] NZLJ 306.

HN Dollimore "New Zealand "Washing-Up" Bills" (1968) 37 The Table 26.

ET Durie "Will the Settlers Settle? Cultural Conciliation and Law" (1996) 8 Otago LR 449.

Walter Iles "New Zealand Experience of Parliamentary Scrutiny of Legislation" (1991) 12 Stat L Rev 165 .

Moana Jackson “Changing Realities: Unchanging Truths" (1994) 10 Austl J L \& Soc’y 115.

KN Llewellyn "The Normative, the Legal and the Law-Jobs: The Problem of Juristic Method" (1940) 49 Yale L J 1355.

David McGee "Concerning Legislative Process" (2007) 11 Otago LR 417.

PG McHugh "The Alienation of Maori Land under Part XXIII and Section 438 of the Maori Affairs Act 1953” (1979) 10 VUWLR 153.

PG McHugh "The legal basis for Maori claims against the Crown” (1988) 18 VUWLR 1.

PG McHugh "Constitutional Voices" (1996) 26 VUWLR 499.

PG McHugh "The Crown's Relationship with Tribal Peoples and the Legal Dynamics for the Resolution of Historical and Contemporary Claims” (2015) 46 VUWLR 875.

Hamish McQueen “Parliamentary Business: A Critical Review of Parliament's Role in New Zealand's Law-Making Process" (2010) 16 Auckland UL Rev 1.

Annie Mikaere "Settlement of Treaty Claims: Full and Final or Fatally Flawed" (1997) 17 NZULR 425.

Vincent O’Malley “Treaty-Making in Early Colonial New Zealand” (1999) 33 NZJH 137.

Palmer, Geoffrey “The Evolution of a Legal System” (2000) 31 VUWLR 175.

Geoffrey Palmer “Law-Making in New Zealand: Is there a Better Way?” (2014) 22 Wai L Rev 1. 
Kenneth A Palmer "Law, Land, and Maori Issues" (1988) 3 Canta LR 322.

Linda Te Aho "Contemporary Issues in Māori Law and Society: Mana Motuhake, Mana Whenua" (2006) 14 Wai L Rev 102.

"The Crown Proceedings Act 1950 (I)" (1952) 28 NZLJ 17.

“The Crown Proceedings Act 1950 (II)" (1952) 28 NZLJ 49.

“The Crown Proceedings Act 1950 (III)" (1952) 28 NZLJ 65.

William Twining "The Idea of Juristic Method: A Tribute to Karl Llewellyn" (1993) 48 U Miami L Rev 119.

K Upston-Hooper "Slaying the Leviathan: Critical Jurisprudence and the Treaty of Waitangi" (1998) 28 VUWLR 683.

Jeremy Waldron "Parliamentary Recklessness" [2008] NZLJ 417.

Jeremy Waldron "Parliamentary Recklessness - II" [2008] NZLJ 458.

Jeremy Waldron "The Half-Life of Treaties: Waitangi, Rebus Sic Stantibus" (2006) 11 Otago LR 161.

G Reports

RP Boast QC "Judge Acheson, The Native Land Court, and the Crown: A Report to the Waitangi Tribunal" (Wai 1040, October 2016).

Crown Forestry Rental Trust Māori Experiences of the Direct Negotiations Process (Crown Forestry Rental Trust, Wellington, 2003) < http://www.cfrt.org.nz/doclibrary/public/thestorehouse/companiondocs/experiences.pdf>.

Cathy Marr "Crown Policy Towards Major Crown-Iwi Claim Agreements of the 1940s and 1950s: A Preliminary Report for the Treaty of Waitangi Policy Unit" (Stout Centre for New Zealand Studies, Victoria University of Wellington, Wellington, 2010). 
Richard Hill "Settlements of Major Maori Claims in the 1940s: A Preliminary Historical Investigation" (Department of Justice, Wellington, 1989): <http://www.nzcpr.com/wpcontent/uploads/2013/01/Richard-Hills-Report.pdf>.

Law Commission Waka Umanga: A Proposed Law for Māori Governance Entities (NZLC R92, 2006).

Law Commission Māori Custom and Values in New Zealand Law (NZLC SP9, 2001).

Office of Treaty Settlements, Ka tika à muri, ka tika à mua: Healing the past, building a future. A Guide to Treaty of Waitangi Claims and Negotiations with the Crown (Office of Treaty Settlements, Wellington, 2015): <https://www.govt.nz/assets/Documents/Red-Book-Healing-the-past-building-afuture.pdf>.

New Zealand Maori Council “Kaupapa: Te Wahanga Tuatahi” (February 1983).

John Wilson "The Origins of Maori Seats" <https://www.parliament.nz/en/pb/researchpapers/document/00PLLawRP03141/origins-of-the-māori-seats\#RelatedAnchor>.

\section{H Dissertations and Theses}

EP Angus "Select Committees of the House of Representatives, New Zealand" (MA thesis, Victoria University College, 1951).

Therese Suzanne Crocker "Settling Treaty Claims: The Formation of Policy on Treaty of Waitangi Claims in the Pioneering Years, 1988-1998” (PhD Thesis, Victoria University of Wellington, 2016).

Guy Finny "New Zealand's Forgotten Appellate Court? The Native Affairs Committee, Petitions and Maori Land: 1871-1900” (LLB (Hons) Dissertation, Victoria University of Wellington, 2013).

Alan Dudley Ward "The History of the East Coast Maori Trust" (MA thesis, Victoria University of Wellington, 1958).

I Parliamentary and Government Materials

$1 \quad$ Appendices to the Journals of the House of Representatives:

(a) Annual Reports of the Native/Māori Affairs Committee (1931-2017) at I3. 
(b) Reports of the Chief Judge of the Native/Māori Land Court (1933-1955) at G6.

(c) Annual Reports of the Native Department/Department of Māori Affairs (1931-1972) at G9, (1973-1990) at E13 and (1991-1993) at E35.

(d) Royal Commission reports:

"Reports of the Native Land Claims Commission" [1921-1922] II AJHR G5.

"Report of Royal Commission to Inquire into Confiscations of Native Lands and other Grievances Alleged by Natives" [1928] II AJHR G7.

"Report of Royal Commission Appointed to Inquire into and Report upon Claims Preferred by Certain Maori Claimants concerning the Pukeroa-Oruawhata (Rotorua Township) Block" [1948] III AJHR G7.

"Report of Royal Commission to Inquire into and Report on Claims Preferred by Members of the Maori Race Touching Certain Lands Known as Surplus Lands of the Crown" [1948] III AJHR G8.

"Report of Royal Commission appointed to Inquire into and Report Upon Claims Preferred by Certain Maori Claimants in Respect of the Tarawera and Tataraakina Blocks" [1951] II AJHR G7.

"Report of the Royal Commission to Inquire into the Future Use of Rangatira B and C Blocks" [1974] IV AJHR H6.

"Report of Commission of Inquiry into Maori Reserved Land" [1975] IV AJHR H3.

"Report of the Royal Commission of Inquiry: The Maori Land Courts" [1980] IV AJHR H3.

(e) Other Reports:

Standing Orders Committee "Report of the Standing Orders Committee: Review of Standing Orders" [1993-1996] XLIII AJHR I18A.

Māori Affairs Committee "Report of the Māori Affairs Committee: Petition 2005/150 of Hariata Baker" [2005-2008] 14 AJHR 809. 
Māori Affairs Committee "Report of the Māori Affairs Committee: Maori Purposes Bill (234-1)" [2008-2011] 15 AJHR 1211.

2 Journals of the House of Representatives (1931-2017).

3 New Zealand Parliamentary Debates (1910-2017), Volumes:

$153,156,167,171,174,177,181,183,185,189,193,194,205,208,211,216,219,223,226$, 230, 237, 240, 243, 247, 250, 253, 256, 260-261, 263, 267, 272, 275, 279, 284, 288, 293, 296, 298, 310, 304, 307, 310, 314, 318, 321, 325, 329, 333, 336, 337, 340-341, 344-345, 349, 354, 358-359, 363-364, 369-370, 376-377, 380-385, 388, 395, 401-402, 407-408, 416, 421, 426-428, 435-436, 441-442, 448-449, 454-455, 460-462, 464, 495, 503, 506, 513, 515, 536-538, 540, 546, $557,579,591,600,602,607,632,644,668,675,708,716-717,721$.

$4 \quad$ Standing Orders:

Standing Orders of the House of Representatives (New Zealand) Relating to Public Business 1929.

Standing Orders of the House of Representatives Relating to Public Business 1951, 1963, 1969 and 1975.

Standing Orders of the House of Representatives 1979, 1985, 1996, 2003, 2011, 2014 and 2017. Standing Rules and Orders of the Legislative Council Relating to Public Business 1929.

Other Government Documents:

Cabinet Office Cabinet Manual 2017.

Legislation Advisory Committee "Legislation Advisory Committee Guidelines: Guidelines on Process and Content of Legislation" (2014 edition).

J National Archives Files:

AADS W3562/178 (6/6/445)

\section{AAFD 811 Series:}

W4198/91 (CAB 244/1/1)

W2347/114/k (CAB 266/2/1) 
W2347/107/a (CAB 266/4/1)

W3738/1334 (CAB 244/1/1)

W3738/1338 (CAB 266/1/1 and 266/4/1)

AAFH 6790 W5510/504 (SS-6-1-MAO-2 and 3) and 506 (SS-6-1-MAO-6)

AALR 873 W5427/737 (40/581)

AAMK 869 Series:

W3074/750/b (24/1/4)

W3074/185/a to c $(6 / 58)$

W3074/205/b (7/6/66)

W3074/206/a to c $(7 / 6 / 66)$

W3074/664/a and b (19/1/254)

W3074/224/b

W3074/805/a

W3074/700 (19/4/84)

W3074/797/b (26/7/2)

W3074/798/a and b (26/7/2)

W3074/799/b and c (26/7/2)

W3074/751/b (24/1/5)

W3074/752/b (24/1/11)

W3074/753/d (24/2/3)

W3074/754/a to c $(24 / 2 / 4)$

W3074/805/a (26/9)

W3074/805/b and c (26/10)

W3074/806/a and b (26/10)

W3074/807/a to c $(26 / 10)$

W3074/808/a and b (26/10)

W3074/1092 (36/6/38)

AAMX 6095 W3430/6 (26/1/12)

AAVN 869 W3599/239 (54/18/2)

AAVN 869 W3599/130 and 131 (26/10)

\section{ABGX 16127 series:}

W3706/12 and 13 (1961-66; 1975-1985)

W4731/117 (1974/44)

W4731/325 (Alt. No MA/2/4/1, 2 and 3) 
W5552/229 (2005/150)

W5189/69 (MA 2/2/1, 2 and 3)

ABIO 7242 W4047/414

ABJZ 869 Series:

W4644/28 (13/0/2)

W4644/50 (19/4/84)

W4644/68 (26/9) and (26/10)

W4644/158 (36/31)

W4644/172 (43/1/13)

W4644/271 (19/4/83)

ABJZ 6878 W4615/16 (81/1/1) and $31(82 / 1 / 1)$

ABJZ 7019 W4644/5 (LEG6/2)

ABOG 869 W5004/9 (6/58/5)

ABWN 6095 W5021/248 (7/685)

ABWN 6095 W5021/690 (23/1099/1)

\section{ACIH 16036 Series:}

MA1/23 (1/15)

MA1/130 (5/13/11)

MA1/133 (5/13/126)

MA1/134 (5/13/142)

MA1/35 (5/13/145)

MA1/135 (5/13/159)

MA1/138 (5/13/182)

MA1/147 (5/13/237)

MA1/343 (19/1/25)

MA1/420 (21/1/12)

MA1/460 (21/4A)

MA1/461 (21/4/1)

MA1/464 (21/4/59)

MA1/1112 (1913/3947)

MAW2459/31 (5/13/52)

MAW2459/237 (21/3/100)

MAW2459/178 and $179(19 / 1 / 344)$ 
MAW2490/269 (54/23/12)

AECZ 18714 MA-MLP1/262/g (1931/8)

AEBE 18507 LE1 series:

LE1/1028 (1933/14)

LE1/1051 (1934/15)

LE1/1075; 1076; 1077 (1935/14)

LE1/1103 and 1104 (1936/16)

LE1/1126 and 1127 (1937/15)

LE1/1154 (1938/16)

LE1/1199 (1941/14)

LE1/1210 (1942/8)

LE1/1224 (1943/13)

LE1/1232 (1943/139, 140 and 141)

LE1/1277 (1946/14)

LE1/1298 and 1299 (1947/16)

LE1/1304 (1947/307)

LE1/1335 (1948/305, 306 and 308)

LE1/1342 (1949/12)

LE1/1360 (1950/15)

LE1/1374 (1951/251)

LE1/1383 (1952/15)

LE1/1527 (1962/12)

LE1/1601 (1966/6)

LE1/1642 (1968/4)

K Office of Treaty Settlements < https://www.govt.nz/organisations/office-of-treaty-settlementsropu/>

Agreement between the Minister of Justice on Behalf of the Crown, and Pukeroa-Oruawhata Trustees and the Proprietors of Ngati Whakaue Tribal Lands Inc., for and on Behalf of the People of Ngati Whakaue, in Relation to Claim Wai 94.

Ahuriri Hapu and the Trustees of the Mana Ahuriri Trust and the Crown, Deed of Settlement of Historical Claims, 2 November 2016. 
Heretaunga Tamatea, Trustees of the Heretaunga Tamatea Settlement Trust, and the Crown, Deed of Settlement of Historical Claims, 26 September 2015.

Ngaruahine, the Trustees of Te Korowai O Ngaruahine Trust, and the Crown, Deed of Settlement of Historical Claims, 1 August 2014.

Ngāti Tūwharetoa, Te Kotahitanga o Ngāti Tūwharetoa and the Crown, Deed of Settlement of Historical Claims, 8 July 2017.

Ngāti Whātua o Kaipara and the Crown, Deed of Settlement of Historical Claims, 9 September 2011.

Rongowhakaata Including Nga Uri O Te Kooti Rikirangi, The Trustees of the Rongowhakaata Settlement Trust and the Crown, Deed of Settlement of Historical Claims, 30 September 2011.

Te Aupōuri and the Crown, Deed of Settlement of Historical Claims, 28 January 2012.

Te Rarawa and the Crown, Deed of Settlement of Historical Claims, 28 October 2012.

L Waitangi Tribunal Documents: <https://www.waitangitribunal.govt.nz/>

RP Boast "The Muriwhenua South and Ahipara Purchases: A Report to the Waitangi Tribunal" (Wai 45, March 1992).

Claudia Geiringer "Muriwhenua Land Claim, Subsequent Maori protest arising from the Crown Land Purchases in Muriwhenua 1850-1865" (Wai 45, April 1993).

Brian D Gilling "The Purchase of the Patetere Block 1873-1881: An Exploratory Report" (Wai 1200, November 1992).

Cathy Marr "Public Works Takings of Maori Land, 1840-1981" (Waitangi Tribunal, Rangahaua Whanui Series, May 1997).

GA Phillipson "The Northern South Island: Part II" (Waitangi Tribunal, Rangahaua Whanui Series, October 1996).

Waitangi Tribunal Te Tau Ihu O Te Waka a Maui: Report on Northern South Island Claims, Volume II (Wai 785, 2008). 
Waitangi Tribunal Muriwhenua Land Report (Wai 45, 1997).

Waitangi Tribunal Te Mohaka Ki Ahuriri Report (Wai 201, 2004).

Waitangi Tribunal Report Turanga Tangata, Turanga Whenua: The Report on the Turanga a Kiwi Claims, Vol II (Wai 814, 2004).

Ben White "Supplementary Report on the West Coast Settlement Reserves: A Report Commissioned by the Waitangi Tribunal for the Taranaki Claim" (Wai 143, February 1996).

M Miscellaneous

Auckland Land Registry, Certificate of Title 897/206.

Trustees of Wi Pere Trust "Submission on the Māori Purposes Bill 2015": $<$ https://www.parliament.nz/en/pb/bills-and-laws/bills-proposedlaws/document/00DBHOH_BILL64510_1/tab/submissionsandadvice>.

$N \quad$ Other website sources

<www.legislation.govt.nz>

$<w w w . m a o r i l a n d o n l i n e . g o v t . n z>$

<www.nzlii.org/nz/legis>

$<w w w . p a p e r s p a s t . n a t l i b . g o v t . n z />$

<www.tekau.maori.nz/PalmerstonNorthMaoriReserveTrust/AboutUs/History.aspx>

<www.tpk.govt.nz>

<www.whakaue.org> 